\title{
Biodiesel: An Overview II
}

\author{
Michelle J. C. Rezende, ${ }^{\oplus *, a}$ Ana Lúcia de Lima, ${ }^{a}$ Bárbara V. Silva, ${ }^{a}$ \\ Claudio J. A. Mota, ${ }^{a, b, c}$ Ednildo A. Torres, ${ }^{c, d, e}$ Gisele O. da Rocha, ${ }^{c, d, f}$ \\ Ingrid M. M. Cardozo, ${ }^{d}$ Kênia P. Costa, ${ }^{a}$ Lilian L. N. Guarieiro, ${ }^{c, g}$ \\ Pedro A. P. Pereira, ${ }^{\circledR c, f}$ Sabrina Martinez $z^{d}$ and Jailson B. de Andrade ${ }^{\circledR c, d, g}$
}

\author{
${ }^{a}$ Instituto de Química, Universidade Federal do Rio de Janeiro, Cidade Universitária, CT, Bloco A, \\ 21941-909 Rio de Janeiro-RJ, Brazil \\ ${ }^{b}$ Escola de Química, Universidade Federal do Rio de Janeiro, Cidade Universitária, CT, Bloco E, \\ 21941-909 Rio de Janeiro-RJ, Brazil
}

'Instituto Nacional de Ciência e Tecnologia em Energia e Ambiente (INCT), Universidade Federal da Bahia (UFBA), 40170-115 Salvador-BA, Brazil

${ }^{d}$ Programa de Pós-Graduação em Energia e Ambiente (PGEnAm), Escola Politécnica, Centro Interdisciplinar em Energia e Ambiente (CIEnAm), Universidade Federal da Bahia (UFBA), 40170-115 Salvador-BA, Brazil

${ }^{e}$ Departamento de Engenharia Química, Universidade Federal da Bahia (UFBA), Escola Politécnica, 40210-630 Salvador-BA, Brazil

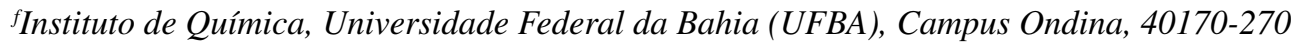 \\ Salvador-BA, Brazil
}

${ }^{g}$ Centro Universitário SENAI CIMATEC, 41650-010 Salvador-BA, Brazil

\begin{abstract}
The crescent number of scientific articles published per year shows that research on biodiesel continues to play an important role to support the growing demand for this biofuel. The second edition of Biodiesel: An Overview presents the worldwide research in the last 15 years. Microalgae biomass is the most studied raw material alternative in this period and several studies have been carried out to develop basic heterogeneous catalysts for biodiesel production. Concerning to production technologies, supercritical conditions and intensification process have been extensively investigated. The development of new antioxidants additives has focused mainly on biomass-derived formulations and there are few studies on biocide candidates. In terms of pollutant emissions, in general, the studies showed that the addition of biodiesel generates lower concentrations of polycyclic aromatic hydrocarbons (PAH), $\mathrm{CO}$ and $n$-alkanes pollutants, but carbonyl compounds, major ions and $\mathrm{NO}_{\mathrm{x}}$ are emitted in a higher concentration compared to pure diesel.
\end{abstract}

Keywords: additives, biodiesel, catalysts, emission, feedstocks, review

\section{Introduction}

Biodiesel plays an increasingly important role in the energy matrix of several countries in the world and its demand is increasing every year. Accordingly, the associated research, development and innovation (R\&D\&I) on biodiesel is also advancing to the same extent. This could be clearly observed by the growing number of publications in scientific search databases. A bibliographic

*e-mail: mjcrezende@gmail.com

This paper is dedicated, in memoriam, to Professor Angelo da Cunha Pinto. search was carried out in the Scopus (Elsevier) database in October 2020 looking for publications that contain the word "biodiesel" in the title, abstract or keywords. A total of 40,492 references were found, and from those, 39,602 papers ( $98 \%$ of them) were published in the last 15 years (2005-2020). Figure 1a shows the number of publications by year.

In turn, the search for publications containing the words "biodiesel" and "review" (or "overview") in the title, abstract or keywords provided a total of 3,411 references. The search was done again in order to ensure that the 

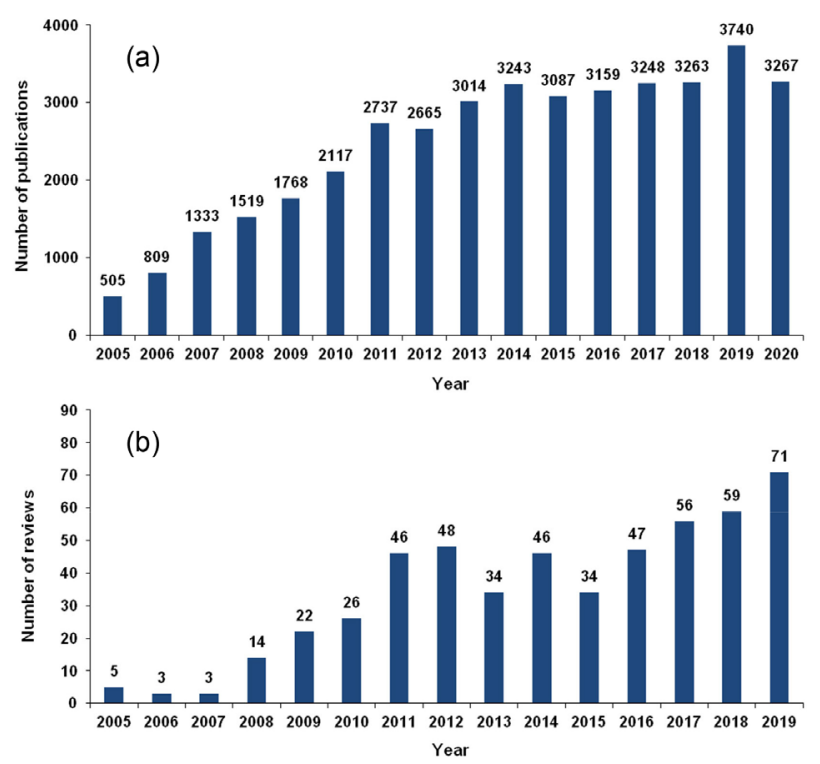

Figure 1. Quantitative of publications (a) and reviews (b) about biodiesel, from 2005 to 2020. Source: Scopus database (October, 2020).

publications are really review articles, now using the same words only in the title. The number was reduced to 583 references. From these, 579 were published between 2005 and 2020. Figure $1 \mathrm{~b}$ shows the number of review articles by year and Table 1 exhibits the top 20 references with the highest number of citations.

Table 1. Ranking of review articles about biodiesel with the highest number of citations in the Scopus database

\begin{tabular}{lc}
\hline Reference & No. citations \\
\hline 1 & 4,051 \\
2 & 3,249 \\
3 & 2,271 \\
4 & 1,448 \\
5 & 1,083 \\
6 & 960 \\
7 & 913 \\
8 & 834 \\
9 & 822 \\
10 & 774 \\
11 & 742 \\
12 & 736 \\
13 & 596 \\
14 & 589 \\
15 & 569 \\
16 & 543 \\
17 & 518 \\
18 & 494 \\
19 & 459 \\
20 & 450 \\
\hline
\end{tabular}

Those reviews approach different aspects about biodiesel. Some of them focus on just one topic, such as new sources of raw material, ${ }^{9}$ analytical methods for biodiesel characterization ${ }^{21}$ and stability of biodiesel. ${ }^{22}$ Others are even more specific by discussing about a type of a specific feedstock, ${ }^{23}$ a specific catalyst aspect ${ }^{24}$ or regarding the oxidative stability of a given type of biodiesel in particular, ${ }^{25}$ just to name few examples. There are also some authors who chose to address the key points and/or news of several topics. In 2005, we published one of the five reviews on biodiesel that year, which is among the 20 most cited in the world. The present article provides an overview of research on biodiesel in the last 15 years, including a brief summary about the evolution of biodiesel regulation in Brazil within the period. In the present paper we also discussed about the use of biodiesel by G20 countries, the recent feedstocks and catalysts for biodiesel production, as well as new technologies. Additionally, the use of additives as an alternative to solve some storage problems and emissions are also discussed.

\subsection{Implementation of biodiesel in Brazil}

Three events were decisive for the implementation of biodiesel in the Brazilian energy matrix: (i) the oil crisis of the 1970s, (ii) the "green revolution" in Brazil that encouraged the Brazilian agribusiness, producing a surplus of vegetable oil, and (iii) the ECO-92 Conference of the United Nations Environment Program. ${ }^{26}$ The ECO-92 took place in Rio de Janeiro, in which there was the recognition of the potential of biofuels as allies in order to achieve the targets set for reducing carbon emissions..$^{27}$

Considering the favorable conditions for implementation of biodiesel as an alternative fuel in the Brazilian energy matrix, in 2002 the Ministry of Science and Technology introduced the ProBiodiesel. ${ }^{28}$ Back then, the ProBiodiesel was a network for research and technological development of biodiesel. This took place by the ordinance No. 702 of the $30^{\text {th }}$ October $2002,{ }^{28}$ aiming both partial and gradual replacement of fossil diesel by biodiesel. After the ProBiodiesel, an Interministerial Executive Committee for Biodiesel (CEIB) was created in 2003, with the purpose of conducting studies about the economic, social and environmental viabilities of a prospective biodiesel industry in Brazil. ${ }^{26,29}$ Based on the studies done by CEIB, in December 2004 the President of Brazil officially launched the Brazilian Program for the Production and Use of Biodiesel (PNPB).$^{30}$ At that time, the Program envisaged different raw materials for biodiesel production, within the context of social inclusion and regional development. Hence, castor oil was initially considered in the pool of feedstocks, but it was proved to be technically unfeasible due to its composition, rich in ricinoleic acid, yielding a biodiesel that does not meet specifications. In addition, 
the economic benefits were also not clear, since the unique composition of castor oil makes it highly valuable for cosmetics and pharmaceuticals. Indeed, after all these years, the major raw materials for the production of biodiesel in Brazil are soybean and tallow (data on section 2). Indeed, both soybean and tallow were agrobusiness activities which already existed at the time the PNPB was launched. These facts highlight some economical barriers for implementing other crops in the pool of biodiesel feedstocks to replace the traditional ones. In January 2005, the law No. 11,097 was published, ${ }^{31}$ which officially establishes the compulsory implementation of biodiesel in the Brazilian energy matrix. This law also determined the ANP (National Agency of Petroleum, Natural Gas and Biofuels) to define acceptable limits of percentage variations of biodiesel in fossil diesel. ${ }^{26,29,32} \mathrm{In} 2008$ the addition of $2 \%\left(\mathrm{v} \mathrm{v}^{-1}\right)$ biodiesel in diesel (B2) became mandatory in the country. ${ }^{33}$ From there to the present day, the biodiesel amount added to fossil diesel was risen gradually. The evolution of the biodiesel percentage increase to mineral diesel is presented in Figure 2.

\subsection{Overview of the biodiesel scenario in G20 countries}

The group of the twenty countries (the G20) is formed by finance ministers and central bank governors of the world's 19 largest economies. Indeed, the G20 is composed

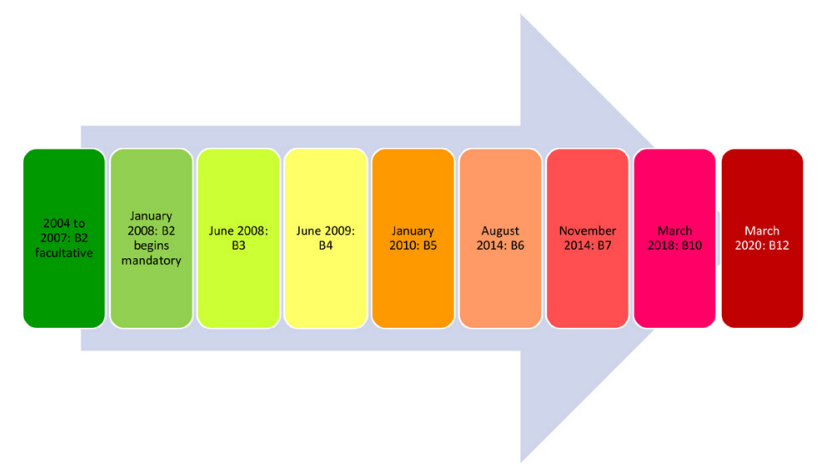

Figure 2. Evolution of the increase in the biodiesel added to mineral diesel in Brazil through the time, up to nowadays (adapted from reference 33).

by Argentina, Australia, Brazil, Canada, China, France, Germany, India, Indonesia, Italy, Japan, the Republic of Korea, Mexico, the Russian Federation, Saudi Arabia, South Africa, Turkey, the United Kingdom, the United States and the European Union. ${ }^{34}$ G20 reflects the wider interests of both developed and emerging economies. The role of the G20 is "to coordinate policies and to make globalization a smoother, more harmonious, and sustainable process. ${ }^{{ }^{35}}$ In this way, international negotiation is favored, integrating the principle of an extended dialogue. ${ }^{35}$ Table 2 shows a brief summary of studies or actions in progress, or already concluded, regarding the biodiesel inclusion in the G20 countries energy matrices.

Table 2. Summary of actions and feedstocks used to introduce biodiesel in the G20 countries energy matrices

\begin{tabular}{|c|c|c|}
\hline Country & History of actions and current situation & Feedstocks \\
\hline Germany & $\begin{array}{l}\text { addition of } 5 \%\left(\mathrm{v} \mathrm{v}^{-1}\right) \text { of biodiesel in fossil diesel was allowed in } 2004 \text { without labelling; } \\
\text { higher blends, except for } 100 \% \text { biodiesel, could be sold, as long as they were labelled; } \\
\text { since } 2015 \text {, there is a } 6 \% \text { greenhouse-gas-emission-reduction target set for transportation fuel, which } \\
\text { should be reached until } 2020 ;^{36,37}\end{array}$ & $\begin{array}{l}\text { rapeseed (most used) } \\
\text { palm, coconut and } \\
\text { soybean oils }{ }^{40}\end{array}$ \\
\hline France & $\begin{array}{l}\text { article No. } 2 \text { Ordinance } 2011-1105 \text { from } 14^{\text {th }} \text { September } 2011 \text { is the legal basis regulating the } \\
\text { French targets; } 41 \\
\text { in 2015, fuel suppliers were subjected to add } 7 \% \text { biofuel to gasoline and } 7.7 \% \text { biofuel to diesel } \\
\text { (in energy content); } \\
\text { fuel suppliers who do not comply with the addition rules pay the pollution tax (Taxe Générale sur } \\
\text { les Activités Polluantes (TGAP)) })^{42}\end{array}$ & $\begin{array}{l}\text { soybean, palm and } \\
\text { sunflower oils }{ }^{42}\end{array}$ \\
\hline Italy & $\begin{array}{l}\text { in 2015, fuel suppliers were subjected to the addition of at least } 5 \% \text { biofuel to conventional automotive } \\
\text { fuels (in energy content) }{ }^{42}\end{array}$ & soybean and palm oils ${ }^{42}$ \\
\hline Russia & $\begin{array}{l}\text { the technical standard in Russia allows adding 5\% biodiesel to conventional fuel since } 2005 \text { (GOST R } \\
52368-2005) ; 3 \\
\text { however, this addition is not mandatory in the country }{ }^{44}\end{array}$ & $\begin{array}{l}\text { sunflower, rapeseed and } \\
\text { soybean oils }{ }^{44}\end{array}$ \\
\hline United Kingdom & $\begin{array}{l}\text { since } 2015 \text {, fuel suppliers have been forced to add at least } 4.75 \% \text { biofuel (by volume) to conventional } \\
\text { automotive fuels, }{ }^{45} \\
\text { in } 2018 \text {, the biofuel addition target increased to } 7.25 \% \text {, besides being expected to be risen } \\
\text { to } 12.4 \% \text { up to } 2032^{45}\end{array}$ & $\begin{array}{l}\text { used cooking oil } \\
\qquad(\mathrm{UCO})^{45}\end{array}$ \\
\hline
\end{tabular}


Table 2. Summary of actions and feedstocks used to introduce biodiesel in the G20 countries energy matrices (cont.)

\begin{tabular}{|c|c|c|}
\hline Country & History of actions and current situation & Feedstocks \\
\hline South Korea & $\begin{array}{l}\text { since } 2002 \text {, biodiesel has been using in public vehicles; }{ }^{46,47} \\
\text { between } 2006 \text { and } 2007,0.5 \% \text { biodiesel was introduced in commercial diesel across the country; } \\
\text { the blend percentage was expected to increase by } 0.5 \% \text { every year, so that automotive diesel would be } \\
\text { added with } 2.0 \% \text { biodiesel from } 2010 \mathrm{on} ;{ }^{46,47} \\
\text { in } 2015 \text {, the } 2.5 \% \text { biodiesel addition became law from the RFS (Renewable Fuel Standard) program; }{ }^{46,47} \\
\text { between } 2018 \text { and } 2020 \text {, the percentage was expected to increase to } 3.0 \%{ }^{48}\end{array}$ & soybean and palm oils ${ }^{48}$ \\
\hline South Africa & $\begin{array}{l}\text { in } 2012 \text {, it was determined the addition of } 5 \% \text { of biodiesel in diesel; }{ }^{49,50} \\
\text { the mandatory biofuel addition was supposed to start on } 2015 ;{ }^{9} \\
\text { but lack of pricing and a final approach about how to apply for subsidies, } \\
\text { made the government miss its } 2015 \text { deadline for mandatory blending; }{ }^{50} \\
\text { costs with UCO have increased in recent years in response to growing local and global demands; } \\
\text { biodiesel producers pay between } 7 \text { and } 8 \text { rand per liter for UCO; } \\
\text { this fact made it unfeasible to promote biofuel use so far }{ }^{51}\end{array}$ & $\begin{array}{l}\text { used cooking oil } \\
\qquad(\mathrm{UCO})^{51}\end{array}$ \\
\hline
\end{tabular}

resolution No. 37 of the Ministry of Energy, from 2006, ${ }^{52}$ established that diesel had

to be mixed with at least $10 \%$ biodiesel;

Argentina in 2007, it was set the initial 5\% biodiesel addition to diesel; $; 2$

currently, the biodiesel market in Argentina is going through one of the worst phases,

soybean oil ${ }^{55}$

as official data show exports interruption has led to a fall of more than

one third of the biodiesel production activities since $2019^{53,54}$

British Columbia, Alberta, Saskatchewan, Manitoba and Ontario established from 2 to $4 \%$

biodiesel addition to diesel between 2006 and 2010; ${ }^{56}$

Canada the 2020 map featured nine biodiesel plants in Canada with nearly 598 million liters of capacity;

in addition, plants with production capacity of over 126 million liters are either under

canola, animal fat and

recycled oils ${ }^{57}$ construction or expansion ${ }^{56}$

most biodiesel users have the B20 blend available; ${ }^{58}$

government incentives facilitate biofuel diffusion since regulated fleet using B20 or more, qualify for biodiesel use credits under the Energy Policy Act of 1992;59

B100 and other high-level biodiesel/diesel blends are less common than B20, as well as there also are the lower blends;

soybean oil ${ }^{60}$

this is due to lack of regulatory incentives and pricing $;{ }^{58}$

in 2020, 134 million gallons of biodiesel were produced, which means 1 million gallons extra when compared to $2019^{60}$

there is no mandate for biodiesel addition, except for a small trial in two counties from the Hainan province; ${ }^{61}$

China most of the produced biofuel is used by industries, only about $30 \%$ of it is used for transportation purposes; ${ }^{61}$

used cooking oil

$(\mathrm{UCO})^{61}$

oil companies own $90 \%$ of gas stations and they have not encouraged biodiesel use ${ }^{61}$

B5 is used in cars, buses and trucks; ${ }^{62}$

the Ministry of Economy, Trade and Industry (METI) issues licenses for operators

Japan to use biodiesel at rates higher than $5 \%$ in trucks and buses; ${ }^{62}$

the use of biodiesel by small-scale power plants and large-scale oil-fired

$(\mathrm{UCO})^{62}$

power plants increased from 2016 on $^{62}$

the biodiesel distribution in the market remains minimal;

the biodiesel share in domestic market will probably grow if a commercially viable

support strategy would be developed to boost a sustainable biodiesel industry; ${ }^{63}$

India

the National Biodiesel Mission (NBM) identified jatropha (Jatropha curcas) as the least edible

oilseed to be applied in order to reach the $20 \%$ biodiesel-addition target set in 2017;

however, the target was not reached due to agronomic and economic issues ${ }^{63}$

currently, the policy Biofuels-2018 approved by the government envisages an indicative target of $5 \%$ biodiesel in diesel by $2030^{64}$

the success in the Indonesian biodiesel blending industry is derived from the biodiesel support program;

this was financed by a charge on exports of palm oil and its by-products; ${ }^{6.5}$

the Oil Palm Estate Fund (BPDPKS) was launched by presidential ordinance 61/2015

and it is responsible for managing the funding; ${ }^{65}$

Indonesia the government plans to expand biodiesel subsidies in order to cover the palm

oil-blended fuel consumption by the mining sector; 66

palm oil ${ }^{68}$

in 2019, Indonesia adopted the B30 programme, which has been expanded

from a previous one with $20 \%$ bio-content;

the government aims start testing for $40 \%$ bio-content in the fuel soon ${ }^{67}$ 
Table 2. Summary of actions and feedstocks used to introduce biodiesel in the G20 countries energy matrices (cont.)

\begin{tabular}{|c|c|c|}
\hline Country & History of actions and current situation & Feedstocks \\
\hline Saudi Arabia & $\begin{array}{l}\text { the economy depends exclusively on its oil sources; } \\
\text { therefore, there is no biodiesel production in the country }{ }^{69}\end{array}$ & - \\
\hline Turkey & $\begin{array}{l}\text { between } 2003 \text { and 2006, many biodiesel production facilities were launched in the country; }{ }^{70} \\
\text { the Turkish Energy Regulatory Agency (EMRA) announced in } 2011 \text { biodiesel addition }(1 \%) \\
\text { would be mandatory from } 2013 \text { and } 2014 ;{ }^{70} \text { however, the Turkish government did not } \\
\text { specify any criteria to the initial stages of the biofuel-sector establishment; } \\
\text { there also are no incentive programs for encouraging new investments in biodiesel facilities }{ }^{70}\end{array}$ & vegetable oil waste ${ }^{70}$ \\
\hline Mexico & $\begin{array}{l}\text { the first law on the Promotion and Development of Bioenergetics was put in force in } 2008 ; ;^{71-73} \\
\text { in 2015, the Law Reform Initiative for the Promotion, Development and Introduction of } \\
\text { Renewable Biofuels was issued; } \\
\text { it determined the compulsory production and use of biofuels throughout the country, }{ }^{71-73} \\
\text { after 2018, all gasoline and diesel sold in gas stations should be added with } 5.8 \%\left(\mathrm{v} \mathrm{v}^{-1}\right) \\
\text { bioethanol and biodiesel, respectively; }{ }^{71-73} \\
\text { biofuel additions are expected to increase to E10 and B10 by } 2021^{71-73}\end{array}$ & $\begin{array}{l}\text { UCO generated by the } \\
\text { food industry }{ }^{74}\end{array}$ \\
\hline Australia & $\begin{array}{l}\text { B5 is the most common biofuel blend used in Australia; } \\
\text { in turn, B20 biodiesel is often sold for commercial operations; } \\
\text { however, biodiesel-use mandates do not cover the country as whole }{ }^{75}\end{array}$ & $\begin{array}{l}\text { animal fats (tallow) and } \\
\text { used cooking oil }\end{array}$ \\
\hline
\end{tabular}

\section{Feedstocks for Biodiesel Production}

In general, vegetable and animal raw materials rich in oils and fats can be used to produce biodiesel. However, it is not easy to find an ideal feedstock for the production of biofuel for internal combustion engines. In regard to economic viability, critical factors such as acreages planted, energy consumption, water quality/quantity ${ }^{76}$ and the possible competition with food and/or pharmaceutical industries, among other possibilities, should be considered carefully. A typical example is the use of jatropha oil for the production of biodiesel in African countries and India. The plant grows in semi-arid regions and has been acclaimed for its alleged ability to resist pests. On the other hand, a large amount of water is needed for irrigation and a large cultivation area is required, creating a potential conflict with food production. ${ }^{77}$

Vegetable oils are a fundamental raw material for biodiesel production. Globally, the most important feedstocks for biodiesel production are palm oil (35\%), soybean oil $(26 \%)$ and rapeseed oil $(16 \%){ }^{78}$ Figure 3 shows the percentage distribution of feedstocks used in the biodiesel production throughout the world. In Brazil, the

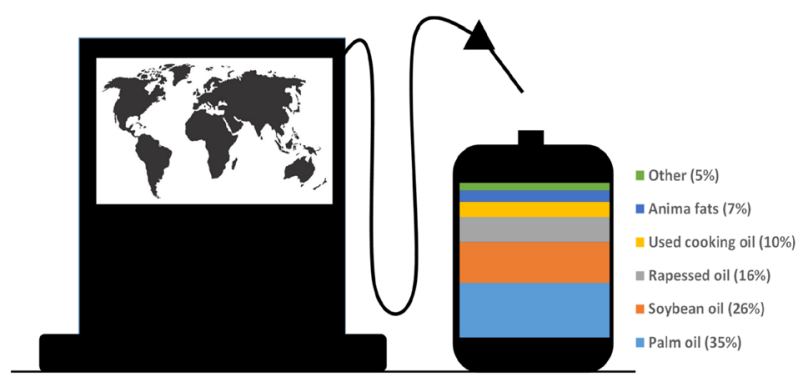

Figure 3. Feedstocks most utilized in the world for biodiesel production. major source for biodiesel production during 2010-2019 were soybean oil and animal fats (Table 3). ${ }^{79}$

In turn, the map below (Figure 4) shows the main raw materials used in the biodiesel production, distributed according to the Brazilian regions, in 2019. Soybean oil has been the main feedstock for production of biodiesel in all regions of Brazil..$^{80}$ Table 4 shows that soybean oil was the main raw material during all months in 2019, while bovine fat and other fatty materials took turns between the second and third sources of biodiesel production..$^{80}$ Even though soybean does not have the highest oil content (among those feedstocks), this commodity has well-established crops traditionally used in the Brazilian food industry. From Table 4 it also is observed Brazil follows a general trend of reusing urban waste, such as the employment of cooking oil for biodiesel production. ${ }^{81}$

Since our last review in $2005,{ }^{15}$ several other oil and fat sources have been investigated for biodiesel production, such as amaranth seeds (Amaranthus palmeri L.), ${ }^{82}$ apricot (Prunus armeniaca L.), ${ }^{83}$ papaya seed oil and stone fruit kernel oil, ${ }^{84}$ safflower (Carthamus tinctorius L.) oil,${ }^{85}$ Moringa oleifera, ${ }^{86}$ Calophyllum inophyllum, ${ }^{87}$ Styrax officinalis L. seed ${ }^{88}$ broiler chicken waste, ${ }^{89}$ duck tallow, ${ }^{90}$ macroalgae, ${ }^{91}$ microalgae (Aurantiochytrium sp. KRS101, ${ }^{92}$ Auxenochlorella protothecoides,${ }^{93}$ Botryococcus braunii, ${ }^{94}$ Botryococcus sp. ${ }^{95}$ Chlorella protothecoides,${ }^{96}$ Chlorella pyrenoidosa,${ }^{97}$ Chlorella sp.,${ }^{98}$ Chlorella sp. KR-1, ${ }^{99}$ Dunaliella tertiolecta, ${ }^{100}$ Enteromorpha compressa, ${ }^{101}$ Euglena sanguinea, ${ }^{102}$ Haematococcus pluvialis, ${ }^{103}$ Isochrysis sp., ${ }^{100}$ Micractinium reisseri SIT04, ${ }^{104}$ Nannochlopsis, ${ }^{103}$ Nannochloropsis gaditana, ${ }^{105}$ Nannochloropsis sp., ${ }^{106}$ Phaeodactylum tricornutum, ${ }^{107}$ Phormidium autumnale, ${ }^{108}$ 
Table 3. Feedstocks for biodiesel production in Brazil (2010-2019), in volume

\begin{tabular}{|c|c|c|c|c|c|}
\hline \multirow{2}{*}{ Feedstock } & \multicolumn{5}{|c|}{ Volume $/ \mathrm{m}^{3}$} \\
\hline & 2010 & 2011 & 2012 & 2013 & 2014 \\
\hline Total & $2,387,639$ & $2,672,771$ & $2,719,897$ & $2,921,006$ & $3,415,467$ \\
\hline Soybean oil & $1,980,346$ & $2,171,113$ & $2,105,334$ & $2,231,464$ & $2,625,558$ \\
\hline Animal fat ${ }^{a}$ & 302,459 & 358,686 & 458,022 & 578,427 & 675,861 \\
\hline Cotton oil & 57,054 & 98,230 & 116,736 & 64,359 & 76,792 \\
\hline \multirow[t]{2}{*}{ Other fatty materials ${ }^{\mathrm{b}}$} & 47,781 & 44,742 & 39,805 & 46,756 & 37,255 \\
\hline & 2015 & 2016 & 2017 & 2018 & 2019 \\
\hline Total & $3,938,873$ & $3,817,055$ & $4,289,351$ & $5,303,632$ & $5,908,237$ \\
\hline Soybean oil & $3,061,027$ & $3,020,819$ & $3,072,446$ & $3,703,066$ & $4,037,087$ \\
\hline Animal fat ${ }^{\mathrm{a}}$ & 738,920 & 622,311 & 720,935 & 860,194 & 830,761 \\
\hline Cotton oil & 78,840 & 39,628 & 12,426 & 49,175 & 66,577 \\
\hline Other fatty materials ${ }^{\mathrm{b}}$ & 60,086 & 134,297 & 483,544 & 691,197 & 973,813 \\
\hline
\end{tabular}

ancludes bovine, chicken and pork fat; bincludes palm oil, peanut oil, turnip oil, sunflower oil, castor oil, sesame oil, canola oil, used cooking oil and other fatty materials. Data from ANP. ${ }^{79}$

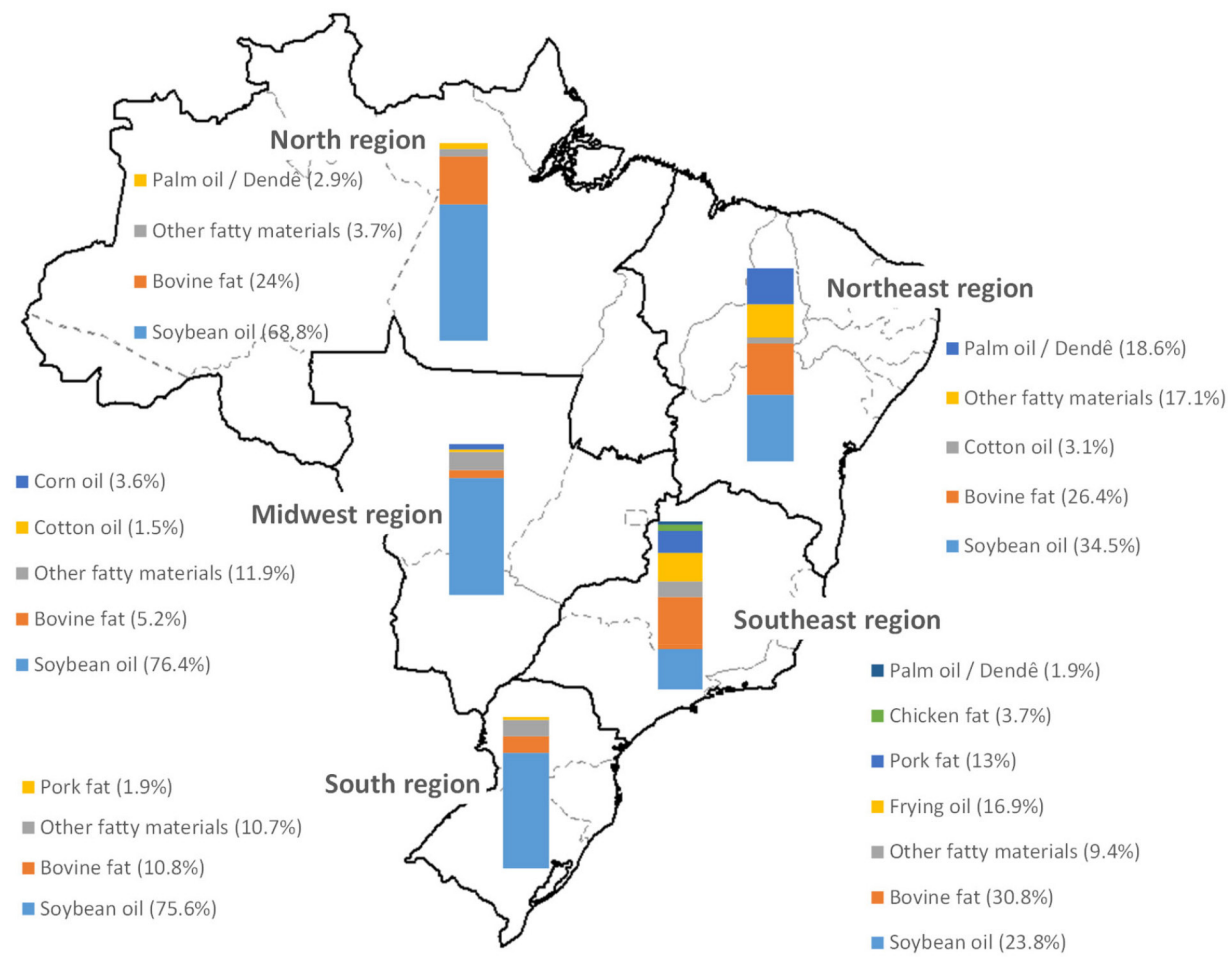

Figure 4. Major biodiesel sources according to Brazilian regions in 2019. Note: only raw materials above $1 \%$ are represented. Data from ANP. ${ }^{80}$

Scenedesmus obliquus, ${ }^{109}$ Scenedesmus obliquus SIT06, ${ }^{104}$ Scenedesmus sp., ${ }^{110}$ Schizochytrium limacinum, ${ }^{111}$ Spirulina maxima, ${ }^{112,113}$ Spirulina sp., ${ }^{114}$ Teraselmis sp., ${ }^{100}$ Thalassiosira pseudonana, ${ }^{107}$ Tribonema minus),${ }^{115}$ mustard oil ${ }_{116}$ mutton fat, ${ }^{117}$ peanut oil, ${ }^{118}$ pine and kapok oil, ${ }^{119}$ pumpkin seed (Cucurbita pepo L.), ${ }^{120}$ Sapindus mukorossi, ${ }^{121}$ soapnut oil, ${ }^{122}$ spent coffee grounds, ${ }^{123,124}$ turnip oil (Raphanus sativus L.), ${ }^{125}$ waste fish oil, ${ }^{126}$ waste sewage sludge, ${ }^{127}$ chicken fat, ${ }^{128}$ insects ${ }^{129}$ and yeasts, ${ }^{130-132}$ among other materials.
Microalgae biomasses, named as third generation energy, are one of the most important raw material alternatives for biodiesel production. ${ }^{133}$ Many microalgae have advantages over conventional terrestrial crops, such as the possibility of establishing companies at low commercial value lands or devastated areas, the continuous crop production, and possibility of using wastewater. ${ }^{134}$ In the literature there are several strategies suggested for increasing the potential microalgae use as a feedstock for biodiesel production. ${ }^{104,135-146}$ Although it is a promising 
Table 4. Feedstocks for biodiesel production in Brazil (2019)

\begin{tabular}{|c|c|c|c|c|c|c|}
\hline Feedstock & January & March & May & July & September & November \\
\hline Soybean oil / \% & 67.00 & 68.30 & 73.25 & 73.13 & 66.71 & 53.7 \\
\hline Bovine fat $/ \%$ & 12.47 & 12.99 & 10.73 & 8.12 & 12.11 & 8.84 \\
\hline Other fatty materials / \% & 12.55 & 12.82 & 10.52 & 12.50 & 12.79 & 30.85 \\
\hline Palm oil/dendê / \% & 3.17 & 1.31 & 2.13 & 1.80 & 2.14 & 2.03 \\
\hline Pork fat $/ \%$ & 2.00 & 2.05 & 1.52 & 2.04 & 1.94 & 1.51 \\
\hline Frying oil / \% & 1.88 & 1.46 & 0.96 & 1.50 & 1.48 & 1.10 \\
\hline Cotton oil / \% & 0.57 & 0.62 & 0.48 & 0.55 & 2.20 & 1.47 \\
\hline Chicken fat / \% & 0.36 & 0.45 & 0.41 & 0.81 & 0.63 & 0.50 \\
\hline
\end{tabular}

Data from ANP. ${ }^{80}$

alternative, it still is at very early stage of development. In addition, the use of conventional microalgae production technologies involves high investments and results in high production costs for biofuel. . $^{147-149}$

In addition to economic viability in the production of biodiesel, the raw material must be able to synthesize secondary metabolites with appropriate physical-chemical characteristics in order to produce biodiesel with good quality. The viscosity of the biodiesel is directly related to the structural characteristics of some constituents such as fatty acids. Biodiesels mainly produced from saturated and linear chain fatty acids generally have higher melting points and tend to solidify at lower temperatures. On the other hand, biodiesels constituted principally from branchedchain fatty acids are likely to be more fluid. ${ }^{150}$ The use of methyl-esters biodiesel by blending it with ethyl esters is a strategy for improving the cold flow properties of biodiesels based on oils with a high content of saturated esters. ${ }^{151}$ Biodiesel with a high content of unsaturated chains is likely to lead to poor oxidative stability. For example, although the microalgae Dunaliella tertioleta has high growth rate and the ability to grow in a brackish environment being a good candidate for biofuel production, a high content of linolenic acid (C18:3) may lead to poor oxidative stability. ${ }^{152}$

The percentage of free fatty acids in the biodiesel matrix is another factor should be taken into account. As the triacylglycerides transesterification usually occurs via basic catalysis, if fatty acids are present, emulsification generally occurs, which makes it difficult the biodiesel purification. Additionally, it causes the catalyst consumption. ${ }^{153}$ For instance, castor seeds (Ricinus communis), with the presence of highly toxic proteins (such as ricin) and other allergenic compounds, ${ }^{154}$ was considered an alternative for biodiesel production. ${ }^{155}$ Although it has a high oil content with the seeds usually containing $40-50 \%$ vegetable oil, they also contain very high levels $(90 \%)$ of ricinoleic acid (12-hydroxy C18:1 $\left.{ }^{\Delta 9}\right)$. Efforts have been made in order to overcome those problems in the biodiesel production in the presence of free fatty acids. ${ }^{156}$ If problems like those ones could be circumvented, raw materials rich in free fatty acids such as castor seeds could have participation in the biodiesel production. This possibility becomes advantageous for less developed Brazilian regions, since this feedstock normally demands less water for its cultivation. ${ }^{155}$

\subsection{Genetic engineering of feedstocks for biodiesel production}

In Biodiesel: An Overview ${ }^{15}$ we mentioned "It may be possible in the future to improve the properties of biodiesel by means of genetic engineering of the parent oils, which could eventually lead to a fuel enriched with certain fatty acids, possibly oleic acid, that exhibits a combination of improved fuel properties." in a reference to Knothe's article, ${ }^{157}$ published in the same year. In the future, genetic engineering's advances will help the production of fatty acids for biodiesel production.

In fact, research over the past few years has led to significant improvements in manipulation of organisms in order to improve biodiesel production. Genetic engineering methods for producing biodiesel from various sources including plants, yeasts, and algae are one of the latest technology that can be a promising alternative for creating truly sustainable, technically viable and cost-competitive biodiesel. ${ }^{158-160}$ Two strategies widely used to improve raw materials for biodiesel production are genetic engineering for (i) length-chain fatty acids and (ii) for increasing the production of monounsaturated fatty acids.

\subsubsection{Genetic engineering of length-chain fatty acids}

Fatty acids are biosynthesized in vivo by either a multifunctional fatty acid synthase type I (FAS I) in eukaryotic cells or the discrete fatty acid synthase complex type II (FAS II) in most bacteria. ${ }^{161}$ In FAS, the acetyl transferase (AT), malonyl-palmitoyl transferase (MPT), keto synthase (KS) and thioesterase (TE) determine the 
fatty acyl chain length. Additionally, the acyl-carrier protein (ACP), which carries fatty acyl intermediates from one enzyme active site to another, is also a key chain-length determinant. ${ }^{162}$

In FAS I, the formation of 3-keto-acyl-ACP occurs by the condensation (Claisen reaction) of acetyl-ACP with malonyl-ACP. The 3-keto-acyl-ACP undergoes a series of reactions: stereospecific carbonyl reduction via keto-acylACP reductase (KR), water elimination via hydroxyl-acylACP dehydratase $(\mathrm{DH})$ and stereospecific reduction of the double bond via enoyl-acyl-ACP reductase (ER). The saturated product enters in a sequence of cycles, which each cycle increases two carbons in the carbon chain. For example, for the formation of palmitic acid (C16:0), this cycle is repeated 7 times. When the required chain length is obtained, the fatty acyl chain can be released as an acyl-Coa (fatty acid with coenzyme A as part of a thioester) or free acid (Scheme 1). ${ }^{161-164}$

Chain length plays an important role for product properties. For example, gasoline-like and diesellike biofuels require short/medium-chain fatty acids (C8-C14). ${ }^{165}$ These compounds have lower viscosity and higher cloud points than long-chain fatty acids (C16-C18). ${ }^{158}$ Finding ways to release fatty acyl intermediates of defined lengths as products is one of the main challenges facing metabolic engineers. Both type I and type II FAS have been engineered to increase medium-chain fatty acyl yields.

In fungal FAS, the processes of loading of malonyl and unloading of the fully elongated acyl-chain are performed by the MPT domain and the domains KR, DH and ER presumably have no direct influence on chain-length regulation. ${ }^{163}$ In Saccharomyces cerevisiae key active sites of the condensation domain (KS) and the transferase domains (MPT and AT) were rationally engineered. A total of five genes were mutated separately and in several combinations. Three genes of KS (F1279Y, G1250S and $\mathrm{M} 1521 \mathrm{~W})$, the domain considered as the most promising target for rewriting chain-length regulation, one gene of MPT domain (R1834K), engineered for reduced malonyl affinity, and one gene of AT(1306A), the domain responsible of loading acetyl in fungal FAS (Scheme 1). The resulting mutated variants of FAS I produced short chain fatty acid, predominantly hexanoic and octanoic, in concentrations which do not occur in the wild type. ${ }^{163}$

\subsubsection{Genetic engineering to increase the production of monounsaturated fatty acids}

In addition to control the chain length, inexpensive and better quality biodiesel may be produced by changing the level of unsaturation of fatty acids. Blending of a fewer amount of saturated and polyunsaturated fatty acids with a higher amount of monounsaturated fatty acids would potentially yield a better quality biodiesel. ${ }^{158}$

Unsaturated fatty acids can arise from more than one synthetic route. In most organisms the mechanism is done by a desaturation of the corresponding saturated fatty acid. Most eukaryotes organisms have an enzyme $\Delta 9$-desaturase which introduces a double bond with $Z$ (cis) geometry in the fatty acid. The enzyme can be named in two ways according the position ability of desaturation: from the carboxyl extremity until the unsaturation, designed with the symbol $\Delta$, and from the methyl extremity until the

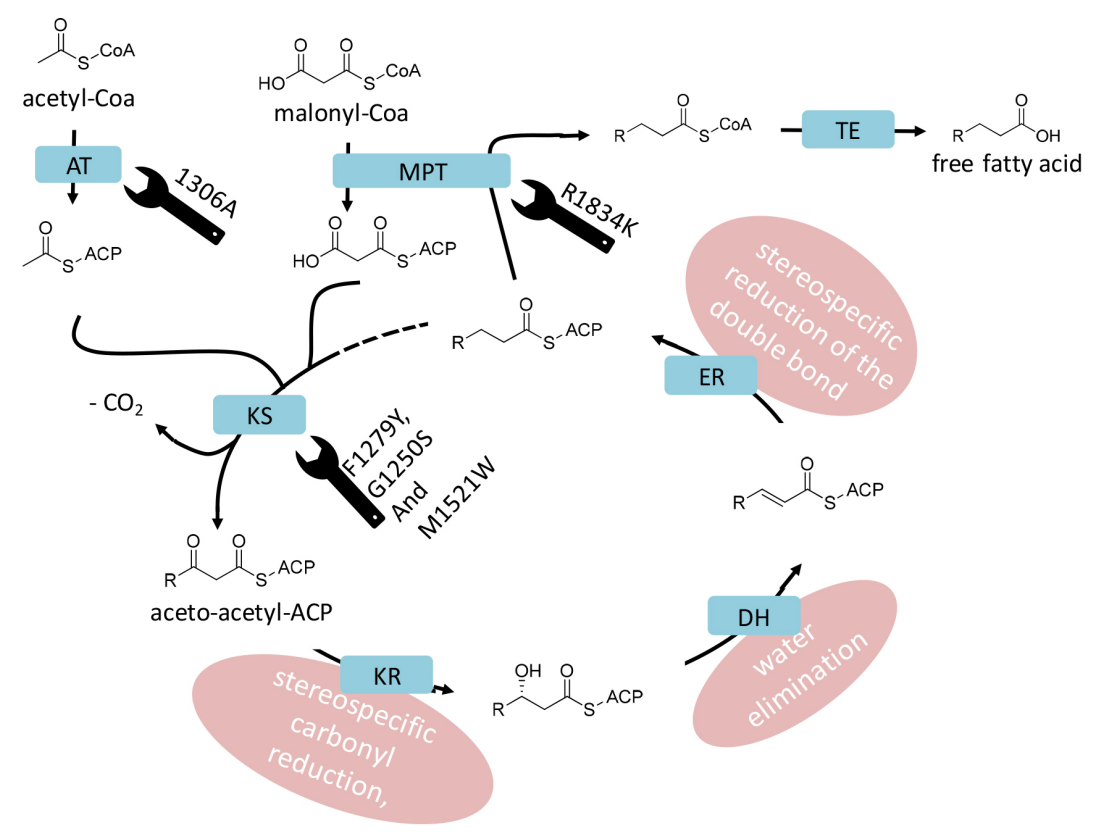

Scheme 1. Biosynthesis of saturated fatty acids. 
unsaturation, which is represented with the symbol $\omega$. The $Z$-configuration of the double bond introduces a 'bend' into the alkyl chain. This interferes with the close association and aggregation of molecules (possible in saturated structures), which helps to maintain the oils and cellular membranes fluidities. ${ }^{164}$

Soybean oil is composed of five fatty acids: palmitic acid (16:0), stearic acid (18:0), oleic acid (18:1), linoleic acid (18:2), and linolenic acid (18:3). The average percentages of these five fatty acids in soybean oil are 10, $4,18,55$ and $13 \%$, respectively. This fatty acid profile results in low oxidative stability (oxidative breakdown of soybean oil), which results in materials in soybeanderived biodiesel that clogs oil filters. Oxidative instability of soybean oil is due to the relatively high percentages of the polyunsaturated fatty acids, such as linoleic and linolenic acids. ${ }^{166}$ In biodiesel a monounsaturated oleic acid (C18:1) is a preferred component as an acyl chain in triacylglycerols, because of its high cetane value, low melting point, and resistance to oxidation. ${ }^{167}$

Soybean seeds have thioesterases, which have preference for palmitoyl- and oleoyl-ACPs. ${ }^{168}$ Palmitic acid (C16:0) is formed from palmitoyl-ACP by catalytic action of fatty acid thiosterase A (FatB), an acyl-ACP thioesterase enzyme. Towards condensation reaction between palmitoyl-ACP and malonyl-ACP by action of the enzyme $\beta$-ketoacyl synthase II (KAS II), stearoyl-ACP is formed. Stearoyl-ACP- $\Delta$ 9-desaturase (SAD) converts stearoyl-ACP in oleyl-ACP. The enzyme $\Delta 12$-desaturase produce linoleoyl-ACP from oleyl-ACP toward a single desaturation step. Linolenoyl-ACP is biosynthesized from linoleoyl-ACP by catalytic action of enzyme $\Delta 15$ desaturase (Scheme 2). ${ }^{154,168}$

The $\Delta 12$-desaturase enzyme is encoded by the FAD2 gene. There are two FAD2 gene families in soybean, designated as FAD2-1 and FAD2-2. ${ }^{169}$ Two different FAD2-1 genes are present in the soybean genome, designated as FAD2-1a and FAD2-1b. Down regulation of FatB would result in decreased levels of saturated fatty acids, primarily a reduction in palmitate, whereas down-regulation of FAD2-1 results in elevated levels of oleate and a reduction in polyunsaturated fatty acids. ${ }^{170}$ The expression of FAD2-1 and FatB was simultaneously down-regulated in a seed-specific fashion, thereby generating soybean oil with a reduced level of palmitic acid content $(<5 \%)$ and significantly increased oleic acid content $\left(>85 \%\right.$ ) (Scheme 2). ${ }^{170}$

These genetic events result simultaneously in the accumulation of oleic acid and a concomitant decrease in polyunsaturated and saturated fatty acids, but not compromised in agronomic performance, including the overall yield, total protein/oil and amino acid profile. Moreover, the biodiesel produced from this extruded oil improved cold flow and enhanced oxidative stability. ${ }^{171}$

Although several genetic engineering processes to improve biodiesel production have yielded satisfactory results at laboratory scale level, commercialization requires scaling up of these processes. In addition, scaling up should reach very high yields and productivities without

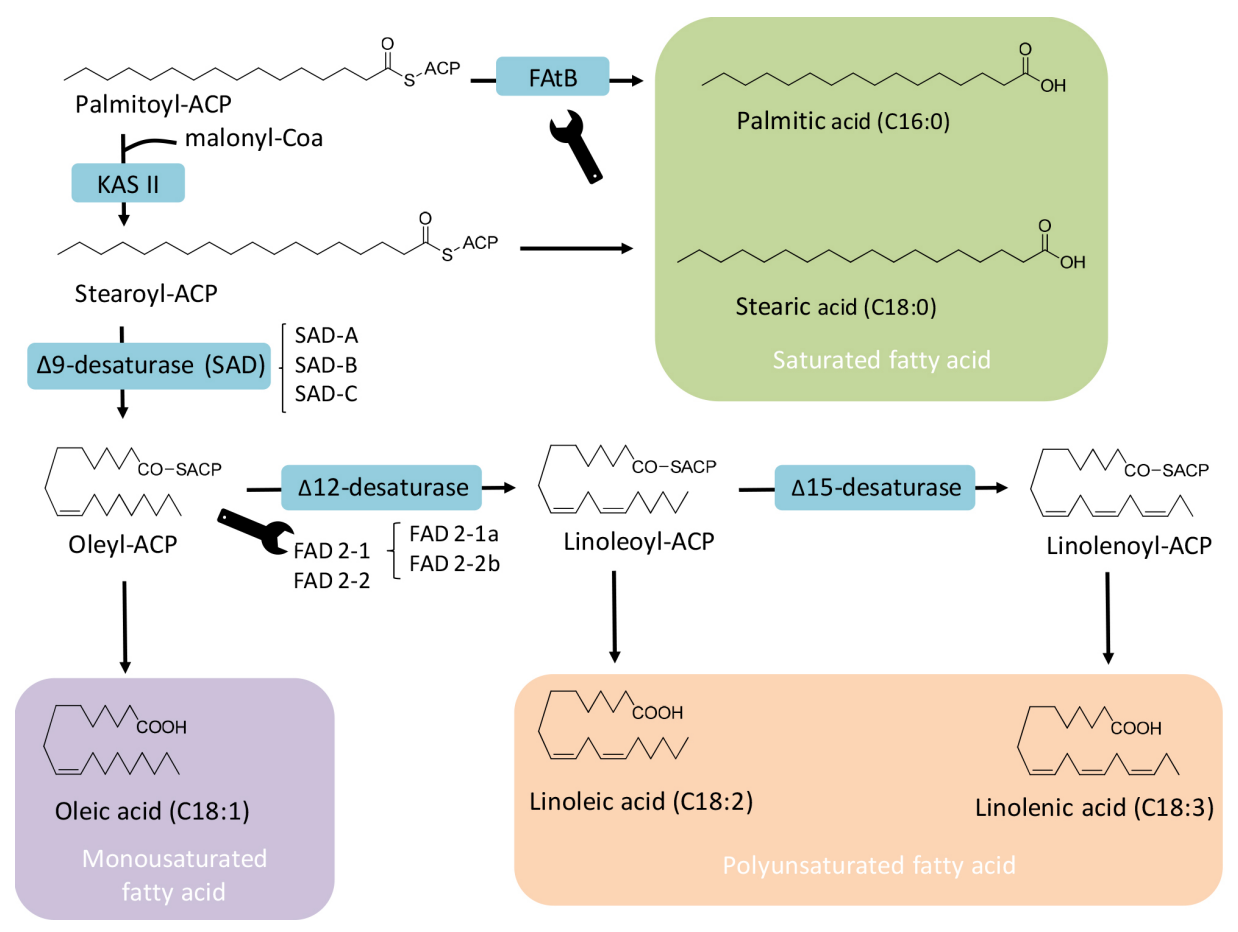

Scheme 2. Biosynthesis of unsaturated fatty acids. 
losing performance, which is the greatest challenge in commercialization. ${ }^{158}$ From the perspective of sustainability, it would be unwise to rely on a single feedstock source to meet diesel fuel demand, even if supply were sufficient to meet demand. The uncertainties surrounding the production of an oilseed crop, as a result of environmental and biotic imposed stresses, could have a significant impact on yield, and thus on supply, in a very unpredictable manner. ${ }^{171}$

\section{Development of Catalysts for Biodiesel Production}

The catalysts can be classified as acid, basic or enzymatic. Yet, they can still be divided into homogeneous or heterogeneous. Figure 5 shows a schematic representation of the various types of catalysts used for biodiesel production with some examples. ${ }^{172,173}$

Basic homogeneous catalysts usually present higher conversion rate, typically 4,000 times higher than acid

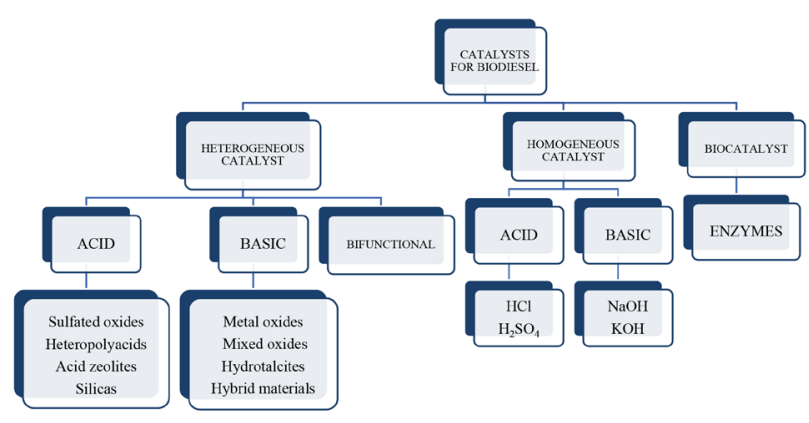

Figure 5. Types of catalysts used in biodiesel production. catalysts, under mild reaction conditions. However, if the free fatty acid content of the feedstock is greater than $2 \%$ they cannot be used. The most traditional homogeneous basic catalysts used in the transesterification of oil and fats are $\mathrm{NaOH}, \mathrm{KOH}, \mathrm{CH}_{3} \mathrm{ONa}$ and $\mathrm{CH}_{3} \mathrm{OK} .{ }^{10}$ Reactions usually occur at temperatures between 40 and $65^{\circ} \mathrm{C}$ within 15 and $45 \mathrm{~min}$. On the other hand, homogeneous acid catalysts are insensitive to the presence of free fatty acids in the raw material. Some typical homogeneous acid catalysts are $\mathrm{H}_{2} \mathrm{SO}_{4}, \mathrm{HCl}$ and $\mathrm{H}_{3} \mathrm{PO}_{4}$. However, reactions are slower compared to basic catalysis. ${ }^{24}$ Some studies ${ }^{174,175}$ have been carried out to develop heterogeneous catalysts for biodiesel production. They allow a number of advantages, such as the possibility of reutilization, regeneration, easy separation of the reaction medium and production of high purity glycerol. ${ }^{174,175}$ Table 5 shows a summary of the different types of catalysts used in the production of biodiesel with their related advantages and drawbacks.

The industrial application of heterogeneous catalysis in biodiesel production is still not viable on a large scale. Most of these catalysts are expensive and show lower catalytic activity when compared to traditional basic homogeneous catalysts. In addition, much of the materials cited in the literature are deactivated due to leaching of the active phase or poisoning of the active sites, caused by impurities present in the raw material or even after exposure of the catalyst to atmospheric air. In some cases, the regeneration of the catalyst can be carried out by heat treatment, when the material withstands high temperatures. In other cases, regeneration is difficult or not effective. Up to now, there

Table 5. Types of catalysts used in the production of biodiesel $1^{12,176-178}$

\begin{tabular}{|c|c|c|}
\hline Type of catalyst & Advantages & Disadvantages \\
\hline Basic and homogeneous & $\begin{array}{l}\text { fast reactions and high conversions } \\
\text { mild reaction conditions } \\
\text { widely available } \\
\text { low costs }\end{array}$ & $\begin{array}{l}\text { sensitive to the content of free fatty acids (FFA) } \\
\text { formation of soap if the FFA content is greater than } 2 \% \\
\text { difficult purification of the products }\end{array}$ \\
\hline Basic and heterogeneous & $\begin{array}{c}\text { faster than acid catalysis } \\
\text { easy catalyst separation } \\
\text { possibility of catalyst reutilization and regeneration } \\
\text { reduced purity of the product }\end{array}$ & $\begin{array}{c}\text { sensitive to oils with high levels of FFA } \\
\text { formation of soap if the content of FFA is greater than } 2 \% \\
\text { leaching of catalyst active sites }\end{array}$ \\
\hline Acid and homogeneous & $\begin{array}{c}\text { insensitive to free fatty acid and water content in the oil } \\
\text { use of low quality triacylglyceride sources }\end{array}$ & $\begin{array}{l}\text { slower than base catalysis } \\
\text { corrosion problems } \\
\text { require more severe reaction conditions } \\
\text { separation of catalyst from the reaction medium is } \\
\text { problematic }\end{array}$ \\
\hline Acid and heterogeneous & $\begin{array}{c}\text { insensitive to free fatty acid } \\
\text { easy separation of the catalyst } \\
\text { low quality triacylglyceride sources } \\
\text { possibility of catalyst reutilization and regeneration }\end{array}$ & $\begin{array}{l}\text { severe reaction conditions } \\
\text { expensive synthesis procedures } \\
\text { long reaction times } \\
\text { leaching of catalyst active sites }\end{array}$ \\
\hline Enzyme & $\begin{array}{c}\text { insensitive to free fatty acid and water content in the oil } \\
\text { use of low quality triacylglyceride sources } \\
\text { low reaction temperatures } \\
\text { simple purification steps }\end{array}$ & $\begin{array}{l}\text { long reaction times } \\
\text { high cost } \\
\text { sensitivity to methanol } \\
\text { enzyme deactivation }\end{array}$ \\
\hline
\end{tabular}


is no promising heterogeneous catalyst for large-scale application. On the other hand, environmental pressures related to waste disposal of the transesterification process, such as washing waters, have motivated studies for the implementation of a heterogeneous catalysis process, and above all, continuous. Solving the problem of leaching and deactivation of heterogeneous catalysts would enable the implementation of continuous processes, with fewer steps of product purification, also including glycerin, which ends up contaminated with most of the homogeneous catalyst.

\subsection{Heterogeneous basic catalysts}

Alkaline earth oxides, such as $\mathrm{CaO}, \mathrm{MgO}$ and $\mathrm{SrO}$, hydrotalcites and silica grafted amines are the most common heterogeneous basic catalyst used in the transesterification of oils and fats for biodiesel production. ${ }^{179} \mathrm{CaO}$ is environmentally friend, non-toxic, low cost and presents low solubility in methanol. In addition, $\mathrm{CaO}$ can be derived from natural sources. ${ }^{180,181}$ Roschat et al. ${ }^{180}$ tested $\mathrm{CaO}$ obtained from several sources as a catalyst in the production of biodiesel from palm oil. About $94 \%$ yield of biodiesel was obtained with 12:1 molar ratio methanol-to-oil for $5 \mathrm{~h}$ at room temperature $\left(30^{\circ} \mathrm{C}\right)$ and $5 \mathrm{wt} . \%$ of catalyst loading. Reutilization tests showed the catalyst can be reused for 4 cycles with conversions above $90 \%$. However, conversion was drastically reduced after 9 cycles, which was mostly ascribed to the exposure to the atmosphere, forming $\mathrm{Ca}(\mathrm{OH})_{2}$ and $\mathrm{CaCO}_{3}$ upon reaction with moisture and $\mathrm{CO}_{2}$, respectively.

Mixed oxides of $\mathrm{CaO}-\mathrm{La}_{2} \mathrm{O}_{3}$, with 1 wt. $\%$ of lithium, were tested in the transesterification of canola oil and methanol for biodiesel production. The calcination temperature of the catalyst affected the surface area and basicity of the material. Around $96 \%$ yield in methyl esters was observed with 15:1 molar ratio methanol-to-oil for $2.5 \mathrm{~h}$ at $65{ }^{\circ} \mathrm{C}$ and $5 \mathrm{wt} . \%$ of catalyst loading. After 4 reaction cycles, the conversion decreased to $85.6 \%$. The authors attributed the deactivation to the poisoning of the active sites by $\mathrm{CO}_{2}$. Leaching tests showed conversion of only $4 \%$ of biodiesel, indicating that it is a minor factor of deactivation. ${ }^{182}$

Hydrotalcites are anionic clays of general formula $\left[\mathrm{M}^{2+}{ }_{(1-\mathrm{x})} \mathrm{M}^{3+}{ }_{\mathrm{x}}(\mathrm{OH})_{2}\right]^{\mathrm{X}+}\left[\mathrm{A}^{\mathrm{n}}\right]_{\mathrm{x} / \mathrm{n}} \cdot \mathrm{yH}_{2} \mathrm{O}$, where $\mathrm{M}^{2+}$ and $\mathrm{M}^{3+}$ are di- (e.g., $\mathrm{Ca}^{2+}, \mathrm{Mg}^{2+}, \mathrm{Zn}^{2+}$ ) and trivalent (frequently $\mathrm{Al}^{3+}$ ) cations in octahedral positions, $\mathrm{A}^{\mathrm{n}-}$ an anion (e.g., $\left.\mathrm{CO}_{3}{ }^{2-}, \mathrm{NO}_{3}{ }^{-}, \mathrm{Cl}^{-}\right)$and $\mathrm{n}$ is within the 0.1-0.5 range. In the absence of calcination, hydrotalcites do not present significant catalytic activity for biodiesel production. The decomposition of hydrotalcite results in a high surface area material of a mixed oxide that exposes strongly Lewis basic sites. ${ }^{183-185}$ Navajas et al. ${ }^{186}$ tested hydrotalcites of $\mathrm{Mg} / \mathrm{Al}$ using a 12:1 molar ratio methanol-to-oil for $8 \mathrm{~h}$ at $60{ }^{\circ} \mathrm{C}$ and 2 wt. $\%$ of catalyst loading. About $50 \%$ conversion of sunflower oil was observed at these conditions. Nowicki et al. ${ }^{187}$ prepared $\mathrm{Zr}$-dopped $\mathrm{Mg}$-Al hydrotalcites with different $\mathrm{Zr} / \mathrm{Mg}$ molar ratios. The catalysts were prepared by the co-precipitation method, calcined at $500^{\circ} \mathrm{C}$ for $3 \mathrm{~h}$ and tested on the transesterification of rapeseed oil using 12:1 molar ratio methanol-to-oil for $6 \mathrm{~h}$ at $100^{\circ} \mathrm{C}$ and $8 \mathrm{wt} . \%$ catalyst loading. The yield of biodiesel was $99.8 \%$.

Mesoporous materials, such as MCM-41 and SBA-15, are formed by siloxane groups in the interior of the pores and silanols groups on the outer surface, where organic or inorganic groups can be grafted (Figure 6). Mesoporous materials present several applications. Among them, as support of heterogeneous catalysts. ${ }^{188}$

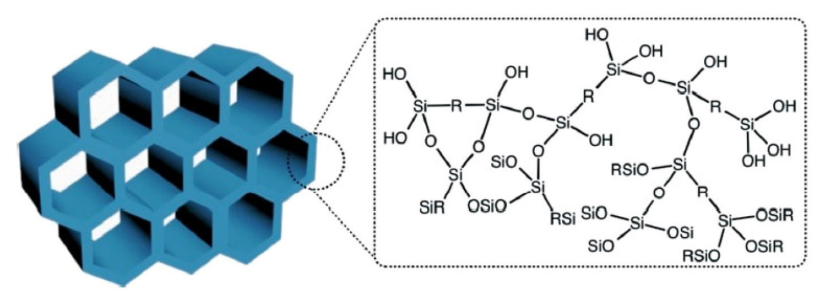

Figure 6. Ordered structure of MCM-41. ${ }^{178}$

The amine 1,5,7-triazabicyclo[4.4.0]dec-5-ene (TBD) was anchored on silica MCM-41 (Figure 7) material by the post-synthesis ${ }^{189}$ and co-condensation methods. ${ }^{188}$ The
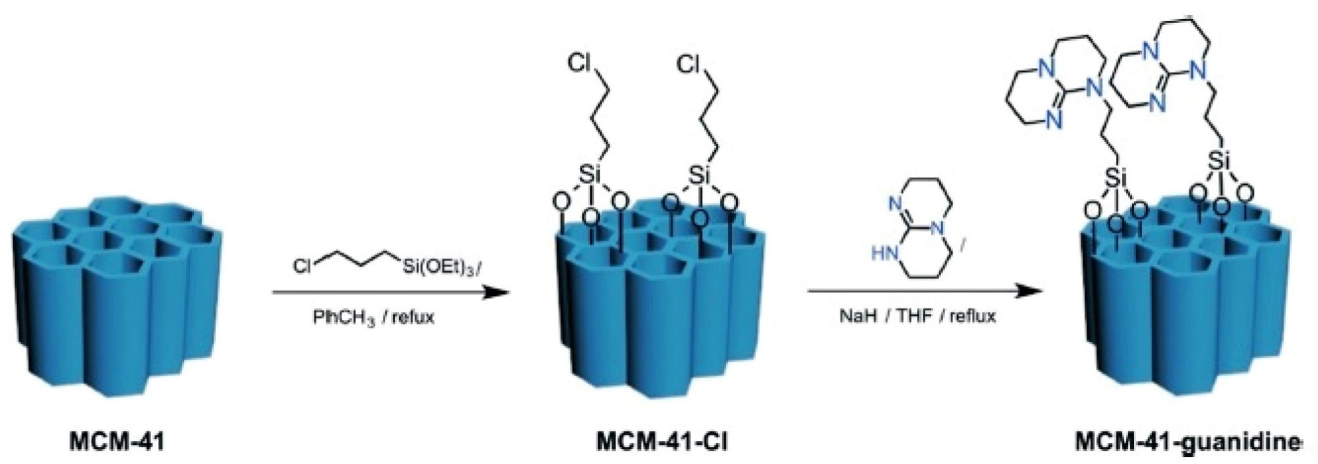

Figure 7. Synthesis of MCM-41-TBD by the post-synthesis methods. ${ }^{189}$ 
post-synthesis method favors the functionalization of the active sites on the external surface and at the entrance of the pores, whereas co-condensation allows a better dispersion of the active sites with more internal functionalization. The materials were tested on the transesterification of soybean oil under mild reaction conditions reaching $99 \%$ biodiesel conversions. The loss of catalytic activity during reuse was attributed to some leaching, but mainly to the neutralization of the active sites by the small amount of free fatty acids present in the oil.

SBA-15 materials loaded with calcium were used in the transesterification of sunflower oil with methanol at $200{ }^{\circ} \mathrm{C}$ for $8 \mathrm{~h}$. The yield of biodiesel at these conditions was $99.1 \%$. Reutilization tests showed no loss of catalytic activity after 5 reaction cycles. The catalysts were simply removed, washed with methanol and dried for further application. The author suggests that the strong interaction between calcium and SBA-15 support $\left(\mathrm{CaSiO}_{3}\right)$ actually occurred. ${ }^{190}$

Zeolites are crystalline aluminosilicates with interconnected cavities and channels, forming pores of molecular dimensions. Many ions, such as $\mathrm{Na}^{+}, \mathrm{Ca}^{2+}, \mathrm{Mg}^{2+}$ and $\mathrm{K}^{+}$can be exchanged on the zeolite structure. This group includes a large number of natural and synthetic minerals that have adsorption capacity, ionic selectivity and are denominated "molecular sieves" because of their crystalline structure. Figure 8 shows some zeolite structures. ${ }^{191-193}$

The transesterification of sunflower oil with methanol was carried out with three different zeolites: mordenite, beta and $\mathrm{X}$, impregnated with sodium metal. The reactions were carried out at $60{ }^{\circ} \mathrm{C}$ for $7 \mathrm{~h}$, using 6:1 molar ratio methanol-to-oil, $10 \mathrm{wt} . \%$ of catalyst loading and stirring rate of $500 \mathrm{rpm}$. The yield of biodiesel was $95.1 \%$ for zeolite X, $65.4 \%$ for zeolite beta and $12.7 \%$ for mordenite. The higher catalytic activity of zeolite $X$ can be explained by the greater number of strong basic sites. ${ }^{194}$ Zeolite X impregnated with sodium was tested in 3 consecutive catalytic cycles and the biodiesel yield decreased from 95.1 to $4.7 \%$. The loss of catalytic activity can be explained by the leaching of the active species, showing that the sodium species occluded in the zeolite pores are responsible for the high catalytic activity of the catalyst. ${ }^{194}$ Table 6 shows some selected studies on the use of heterogeneous basic catalysts in transesterification of vegetable oil with methanol for biodiesel production.

\subsection{Heterogeneous acid catalysts}

The use of heterogeneous acid catalysts allows the use of low quality raw material, with high levels of fatty acids and water, as well as the easy separation of the catalyst and possibility of reutilization. Various materials can be highlighted, such as sulfated metal oxides, acid zeolites, mesostructured silica materials, heteropolyacids, ionic liquid and solid acid catalysts derived from biomass, such as biochar, activated carbon, biomass residue and refined carbohydrate. ${ }^{243,244}$

Jiménez-Morales et al. ${ }^{245}$ incorporated aluminum atoms into the structure of SBA-15 by the post-synthesis method. The acidity of the material was linked to the aluminum content and the activation temperature. Transesterification of sunflower oil with methanol at $200{ }^{\circ} \mathrm{C}$ for $4 \mathrm{~h}$, using 12:1 molar ratio methanol-to-oil and $600 \mathrm{rpm}$ agitation, yielded $82 \%$ of biodiesel. The catalyst was reused in three successive reactions, with no pre-treatment, with a loss of $7 \%$ of the catalytic activity. Deactivation was explained in terms of the blocking of the active sites of the catalyst. Chemical analysis did not indicate any loss of aluminum atoms, confirming there was no leaching of the active phase.

Heteropolyacid, such as $\mathrm{H}_{3} \mathrm{PMo}_{12} \mathrm{O}_{40}$ (HPMo) supported on niobia, was tested in the reaction macaw palm oil, with high content of free fatty acids, using 90:1 molar ratio ethanol-to-oil at $210^{\circ} \mathrm{C}$ and 20 wt. $\%$ of catalysts. The yield of biodiesel was $99.7 \%$. Reutilization tests indicated a decrease of the yield to $11 \%$ after 3 reaction cycles, which was ascribed to the decrease in the acidity of the catalyst due to the blocking of the active sites. ${ }^{246}$

A matrix of mixed titanium and silicon oxides was tested in the transesterification of waste cooking oil using 30:1 molar ratio of methanol to oil for $4 \mathrm{~h}$ at $65^{\circ} \mathrm{C}$ and

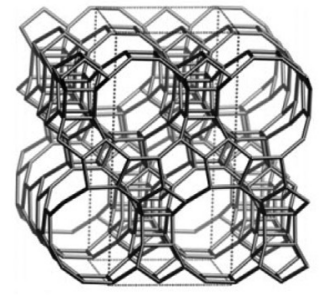

(a)

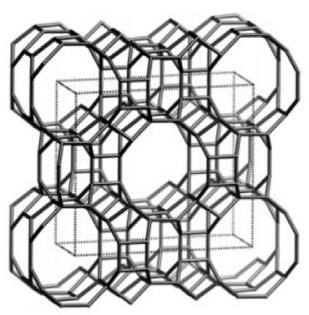

(b)

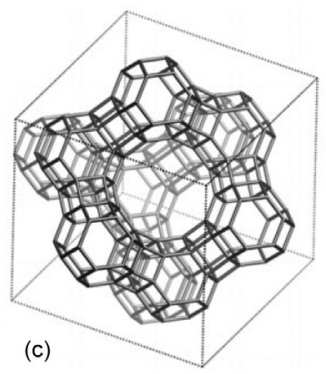

Figure 8. Structure of (a) zeolite beta, (b) zeolite mordenite and (c) zeolite faujasite. 
Table 6. Basic heterogeneous catalysts used for biodiesel production

\begin{tabular}{|c|c|c|c|c|c|c|c|}
\hline Catalyst & $\begin{array}{c}\text { Catalyst } \\
\text { loading / wt.\% }\end{array}$ & Vegetable oil & $\begin{array}{c}\text { Molar ratio } \\
\text { (alcohol:oil) }\end{array}$ & $\begin{array}{c}\text { Temperature / } \\
{ }^{\circ} \mathrm{C} \\
\end{array}$ & time / h & Yield / \% & Reference \\
\hline $\mathrm{CaO}$ & 0.4 & soybean & $14: 1$ & 60 & 2 & 91 & 195 \\
\hline $\mathrm{CaO}$ & 7.5 & residual & $15: 1$ & 65 & 6 & 90 & 196 \\
\hline $\mathrm{CaO}$ & 5 & jatropha & $15: 1$ & 65 & 6 & 89.9 & 197 \\
\hline $\mathrm{SrO}$ & 3 & palm & $9: 1$ & 65 & 1 & 95.2 & 198 \\
\hline $\mathrm{CaO}$ & 6 & palm & $15: 1$ & 65 & 2 & 97 & 199 \\
\hline $\mathrm{CaO}$ & 8 & sunflower & $6: 1$ & 65 & 3 & 95 & 200 \\
\hline $\mathrm{CaO} / \mathrm{MgO}$ & 3 & jatropha & $25: 1$ & 120 & 3 & 90 & 201 \\
\hline $\mathrm{CaO} / \mathrm{MgO}$ & 2 & palm & $15: 1$ & 60 & 3 & 86.6 & 202 \\
\hline $\mathrm{MgO} / \mathrm{ZnO}$ & 3 & jatropha & $25: 1$ & 120 & 3 & 83 & 203 \\
\hline $\mathrm{MgO} / \mathrm{ZrO}_{2}$ & 3 & soybean & $20: 1$ & 150 & 6 & 99 & 204 \\
\hline $\mathrm{CaO} / \mathrm{La}_{2} \mathrm{O}_{3}$ & 4 & jatropha & $24: 1$ & 60 & - & 87 & 205 \\
\hline $\mathrm{CaO} / \mathrm{MgO}$ & 1 & soybean & $12: 1$ & 70 & 2 & 98.4 & 206 \\
\hline $\mathrm{CaO} / \mathrm{SnO}_{2}$ & 8 & soybean & $12: 1$ & 70 & 6 & 89.3 & 207 \\
\hline $\mathrm{TiO}_{2} / \mathrm{MgO}$ & 10 & residual & $50: 1$ & 160 & 6 & 92.3 & 208 \\
\hline $\mathrm{KBr} / \mathrm{CaO}$ & 3 & residual & $12: 1$ & 65 & 1.8 & 83.6 & 209 \\
\hline $\mathrm{Zr} / \mathrm{CaO}$ & 15 & soybean & $15: 1$ & 65 & 3 & 99 & 210 \\
\hline $\mathrm{CaO} / \mathrm{NaY}$ & 30 & soybean & $9: 1$ & 65 & 3 & 95 & 211 \\
\hline Ce/HUSY & 5 & soybean $^{\mathrm{a}}$ & $30: 1$ & 200 & 24 & 99.8 & 212 \\
\hline $\mathrm{KOH} / \mathrm{NaY}$ & 10 & palm & $15: 1$ & 60 & 3 & 91.1 & 213 \\
\hline $\mathrm{KOH} /$ zeolite & 3 & palm & $7: 1$ & 60 & 2 & 95.1 & 214 \\
\hline $\mathrm{K} / \mathrm{NaX}$ & 16 & soybean & $16: 1$ & 60 & 3 & 95.2 & 215 \\
\hline KOH/ZSM5 & 18 & sunflower & $12: 1$ & 60 & 24 & 95 & 216 \\
\hline $\mathrm{K} / \mathrm{MgAl}$ & 7 & palm & $30: 1$ & 100 & 6 & 86.6 & 217 \\
\hline $\mathrm{Na}_{2} \mathrm{ZrO}_{3}$ & 3 & soybean & - & 65 & 3 & 98 & 218 \\
\hline TMG/SBA-15 & 5 & soybean & $15: 1$ & 70 & 12 & 92 & 219 \\
\hline $\mathrm{MgAl}$ hydrotalcite & 4 & jatropha & $12: 1$ & 65 & 6 & 75.2 & 220 \\
\hline MgAl hydrotalcite & 2 & sunflower & $48: 1$ & 60 & 24 & 96 & 221 \\
\hline MgAl hydrotalcite & 1.5 & residual $^{\mathrm{b}}$ & $6: 1$ & 80 & 2.5 & 95.2 & 222 \\
\hline MgAl hydrotalcite & 2.5 & soybean & $9: 1$ & 65 & 4 & 97 & 223 \\
\hline MgAl hydrotalcite & 1 & jatropha & $4: 1$ & 45 & 1.5 & 95.2 & 224 \\
\hline $\mathrm{CaFeAl}$ & 6 & soybean & $12: 1$ & 60 & 1 & 90 & 225 \\
\hline $\mathrm{K} / \mathrm{TiO}_{2}$ & 6 & canola & $36: 1$ & 65 & 3 & 81 & 226 \\
\hline $\mathrm{CaO} / \mathrm{SiO}_{2}$ & 5 & palm & $9: 1$ & 65 & 3 & 90.2 & 227 \\
\hline $\mathrm{CaO} / \mathrm{SiO}_{2}$ & 5 & soybean & $16: 1$ & 60 & 8 & 95.2 & 228 \\
\hline $\mathrm{CaO} / \mathrm{MgO} / \mathrm{Al}_{2} \mathrm{O}_{3}$ & 12.5 & cotton $^{\mathrm{a}}$ & $0.77: 1$ & 95 & - & 94.6 & 229 \\
\hline $\mathrm{KOH} / \mathrm{Al}_{2} \mathrm{O}_{3}$ & 15 & residual & $9: 1$ & 70 & 2 & 96.8 & 230 \\
\hline $\mathrm{K} / \gamma-\mathrm{Al}_{2} \mathrm{O}_{3}$ & 3 & soybean & $24: 1$ & 60 & 1 & 98.5 & 231 \\
\hline $\mathrm{CaO} / \gamma-\mathrm{Al}_{2} \mathrm{O}_{3}$ & 9 & palm & $15: 1$ & 60 & 3 & 86.4 & 232 \\
\hline $\mathrm{KOH} / \mathrm{Nd}_{2} \mathrm{O}_{3}$ & 6 & soybean & $12: 1$ & 60 & 3 & 89.7 & 233 \\
\hline $\mathrm{KBrO}_{3} / \mathrm{Nd}_{2} \mathrm{O}_{3}$ & 6 & soybean & $12: 1$ & 60 & 3 & 74.0 & 233 \\
\hline $\mathrm{CaTiO}_{3} / \mathrm{CaO}$ & 10 & sunflower & $6: 1$ & 60 & 10 & 98.1 & 234 \\
\hline $\mathrm{CaSn}(\mathrm{OH})_{6}$ & 3 & sunflower & $10: 1$ & 65 & 3 & 94 & 235 \\
\hline $\mathrm{CaMnO}_{3}$ & - & canola & $6: 1$ & 60 & 10 & 92 & 236 \\
\hline $\mathrm{CaO} / \mathrm{CoFe}_{2} \mathrm{O}_{4}$ & 1 & soybean & $15: 1$ & 70 & 5 & 87.4 & 237 \\
\hline $\mathrm{KNO}_{3} / \mathrm{Al}_{2} \mathrm{O}_{3}$ & 6.5 & soybean & $15: 1$ & 65 & 7 & 87 & 238 \\
\hline DCOD /SBA-15 & 8 & soybean & $15: 1$ & 65 & 15 & 93 & 239 \\
\hline GPMS/silica gel & 0.5 & soybean & $20: 1$ & 80 & 3 & 99 & 240 \\
\hline TMPAOH/SBA-15 & 2.5 & soybean & $12: 1$ & 65 & 0.5 & 99 & 241 \\
\hline TBD/SBA-15 & 1.05 & soybean & - & 70 & 4 & 100 & 242 \\
\hline
\end{tabular}

${ }^{a}$ Reaction with ethanol; ' reaction with both ethanol and methanol. HUSY: zeolite; TMG: 1,1,3,3-tetramethylguanidine; DCOD: 1,3-dicyclohexyl2-octylguanidine; SBA-15: mesoporous Santa Barbara amorphous-15; GPMS: 3-( $N, N$ '-dicyclohexylguanidine)-propyltrimethoxysilane; TMPAOH: tetraalkylammonium hydroxides; TBD: 1,5,7-triazabicyclo[4.4.0]dec-5-ene.

5 wt.\% of catalyst loading, yielding $98 \%$ of biodiesel. Reutilization tests showed no significant loss of catalytic activity after 4 successive cycles. Nevertheless, the catalyst needed to be washed, dried and calcined at $700{ }^{\circ} \mathrm{C}$ between 
the reaction cycles. The loss of catalytic activity in the fifth cycle is due to the leaching of the active species. ${ }^{247}$

The use of heterogeneous acid catalysts allows the use of raw materials of high free fatty acids (FFA) content, which are cheaper and can be used without the need of additional pre-treatment. It also allows the simultaneous esterification and transesterification of oils with high content of fatty acids. ${ }^{248}$ Table 7 shows some selected studies on the use of heterogeneous acid catalysts for biodiesel production.

\subsection{Enzymatic catalysts}

Enzymes, such as lipases, are capable of producing high purity biodiesel at moderate reaction temperatures. However, the reaction rate is slower than acid and basic catalysis and the high cost of the lipases limits its industrial application. In addition, some enzymes deactivate in the presence of methanol. Although it still is an expensive process, the immobilization of enzymes is an interesting alternative. For instance, immobilization of the enzyme in a polymer or resin can make the process less expensive, while allowing the reutilization of the enzyme. ${ }^{269-271}$

Enzymatic reactions are insensitive to free fatty acids and water content in the raw material, whistle demanding lower energy consumption and producing purer glycerol phase. Notwithstanding, the costs are still high, limiting the process to be used in large scale. Some of the lipases most reported in the literature are: $C$. antarctica (Novozym 435), Candida sp. 99-125, C. rugosa, Trichosporon asahii MSR54, Yarrowia lipolytica. Table 8 shows some selected literature on biodiesel production with methanol using enzymatic catalysis. ${ }^{272-274}$

\section{Biodiesel Production Technology}

Searching for renewable energy sources to ensure economic development with social inclusion without environmental aggression is a challenge all over the world. Over the years, most of researching related to biodiesel production pursues alternative production routes which maintain the high reaction yields. Furthermore, it is interesting these new production routes decrease the operating cost of the processes, which is one of the main disadvantages for the economic viability of biodiesel production and commercialization. The transesterification process is the main technology to produce biodiesel in industrial units in Brazil. Nowadays, that production occurs mostly on an experimental scale with plants of small capacity.

The biodiesel price to the consumer is lower than fossil diesel. This can be explained by the reduction of governmental taxes. ${ }^{295}$ The strategy in Brazil is decreasing

Table 7. Acid heterogeneous catalysts used for biodiesel production (with methanol)

\begin{tabular}{|c|c|c|c|c|c|c|c|}
\hline Catalyst & $\begin{array}{c}\text { Catalyst / } \\
\text { wt.\% }\end{array}$ & Vegetable oil & $\begin{array}{l}\text { Molar ratio } \\
\text { (alcohol:oil) }\end{array}$ & Temperature $/{ }^{\circ} \mathrm{C}$ & time $/ \mathrm{h}$ & Yield / \% & Reference \\
\hline $\mathrm{TiO}_{2} / \mathrm{SO}_{4}{ }^{2-}$ & 2 & cottonseed & $12: 1$ & 230 & 8 & 90 & 249 \\
\hline $\mathrm{ZrO}_{2} / \mathrm{SO}_{4}{ }^{2-}$ & 1 & palm kernel & $6: 1$ & 200 & 1 & 90.3 & 250 \\
\hline$\left[\mathrm{CyN}_{1,1} \operatorname{PrSO}_{3} \mathrm{H}\right][p-\mathrm{TSA}]$ & 3 & palm & $24: 1$ & 120 & 2.5 & 98.4 & 251 \\
\hline $\mathrm{Cs}_{2 \cdot 5} \mathrm{H}_{0 \cdot 5} \mathrm{PW}_{12} \mathrm{O}_{40}$ & 3 & sesame & $40: 1$ & 260 & 1 & 92 & 252 \\
\hline Sugarcane bagasse- $\mathrm{H}_{2} \mathrm{SO}_{4}$ & 1 & waste cooking & $18: 1$ & 66 & 5 & 94 & 253 \\
\hline Cellulose- $\mathrm{H}_{2} \mathrm{SO}_{4}$ & 10 & waste cooking & $20: 1$ & 80 & 3 & 95 & 254 \\
\hline Rice husk char- $\mathrm{H}_{2} \mathrm{SO}_{4}$ & 5 & waste cooking & $20: 1$ & 110 & 15 & 87.5 & 255 \\
\hline Sulfonated lignin & 10 & waste vegetable & $35: 1$ & 65 & 6 & 56.8 & 256 \\
\hline $\mathrm{SO}_{4}{ }^{2-} / \mathrm{ZrO}_{2} / \mathrm{MCM}-41$ & 14.6 & sunflower $^{\mathrm{a}}$ & $12: 1$ & 200 & 6 & 91.5 & 257 \\
\hline $\mathrm{SO}_{4} / \mathrm{Fe}-\mathrm{Al}-\mathrm{TiO}_{2}$ & 3 & waste cooking & $10: 1$ & 90 & 2.5 & 96.0 & 258 \\
\hline $\mathrm{SO}_{4}{ }^{2-} / \mathrm{TiO}_{2}-\mathrm{SiO}_{2}$ & 3 & waste cooking & $9: 1$ & 200 & 6 & 92.0 & 259 \\
\hline Sulfonated carbon & 5 & corn acid & $1: 19.95$ & 65 & 4.5 & 91.7 & 260 \\
\hline$\left[\mathrm{BHSO}_{3} \mathrm{MIM}\right]\left[\mathrm{HSO}_{4}\right]$ & 9.17 & palm & $11: 1$ & 108 & 6.43 & 98.9 & 261 \\
\hline Montmorillonite clay & 5 & jatropha & $6: 1$ & 110 & 2.5 & 98.0 & 262 \\
\hline Sulfonated graphene & 10 & palm & $20: 1$ & 100 & 10 & 98.0 & 263 \\
\hline Sulfonated carbon & 5 & waste palm & $12: 1$ & $65-70$ & 12 & 92.6 & 264 \\
\hline $\mathrm{CexH}_{3-3 \mathrm{x}} \mathrm{PW}_{12} \mathrm{O}_{40}$ & 2.2 & waste cooking & $21: 1$ & 65 & 12 & 98.0 & 265 \\
\hline Carbonized coconut & 6 & palm & $30: 1$ & 60 & 6 & 88.2 & 266 \\
\hline $\mathrm{FeCl}_{3}$-resin & 8 & waste cooking & $10: 1$ & 90 & 2 & 92.0 & 267 \\
\hline KIT-5-PTA & 26.5 & waste cooking & $6: 1$ & 70 & 4 & 93.0 & 268 \\
\hline
\end{tabular}

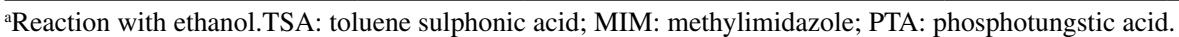


vehicle emissions, without changes in conventional diesel engines according to the government law. ${ }^{30}$ The reduction of taxation is very important for biodiesel be used in high proportion.

Biodiesel is mostly produced by the transesterification of triacylglycerides (usually vegetable oils, but it also can be an animal fat or recycled oil). Despite the enormous limitations of homogeneous catalysts, most biodiesel is produced using alkaline and homogeneous catalysis. This is due to the fact it is much faster kinetically than transesterification using solid catalysts and economically viable. Extensive research is being conducted to develop basic heterogeneous catalysts, as discussed on section 3 . In addition to the advantages mentioned in the previous section, the use of heterogeneous catalysts does not produce soaps by neutralizing free fatty acids. However, there are still major bottlenecks to be overcome because these processes require expensive refined vegetable oil as a raw material and are sensitive to water and free fatty acid content in the raw material.

In the current process, the triacylglycerides are stored and, after acid correction, it is transferred to the principal reactor. Then, either vegetable oil, animal fat or recycled oil reacts with an alcohol (methanol or ethanol) in the presence of a catalyst $(\mathrm{KOH}$ or $\mathrm{NaOH})$ producing a mixture of fatty acid alkyl esters and glycerol. ${ }^{296,297}$ The reaction is completed within $40 \mathrm{~min}$, at temperatures between 30 and $40{ }^{\circ} \mathrm{C}$.
Following, it is necessary a separation step of the biodiesel (main product) from the raw glycerine (secondary product) by decantation or centrifugation. The separation step is one of the most important steps in the biodiesel production, since it is essential for the product specification according to legislation. ${ }^{298}$ The fuel should have similar characteristics to conventional diesel in terms of their main characteristics. In the case it does not scope the requested specification, it needs to be reprocessed. The type of material, reagents and operational conditions (temperature, catalyst, alcohol-to-oil molar ratio, and reaction time) used in the transesterification influence the biodiesel yield. ${ }^{1}$

Generally, alcohol in excess is used in order to increase the biodiesel yielding and to permit its phase separation from the glycerine formed during the transterification reaction. In turn, the alcohol content in the glycerine can be recovered and reused in the process. Accordingly, glycerine can be purified and utilized, for instance, in the cosmetic and personal care applications, pharmaceutical applications, and paper industry, among others. ${ }^{299}$

During the transesterification process several steps are required to separate the main product due to the formation of saponified materials. Besides that, another disadvantage of the transesterification process is the raw materials characteristics, which should have low water content and low acidity. In this context, new alternative routes have been researched over the years in order to overcome

Table 8. Enzymatic catalysts used for biodiesel production with methanol

\begin{tabular}{|c|c|c|c|c|c|}
\hline Catalyst & Vegetable oil & Temperature $/{ }^{\circ} \mathrm{C}$ & time $/ \mathrm{h}$ & Yield / \% & Reference \\
\hline Candida antarctica (Novozym 435) & sunflower oil & 45 & 50 & $>99$ & 275 \\
\hline Candida antarctica (Novozym 435) & cotton seed oil & 50 & 7 & 91.5 & 276 \\
\hline Candida antarctica (Novozym 435) & palm kernel oil ${ }^{\mathrm{a}}$ & 40 & 4 & 63 & 277 \\
\hline Candida antarctica (Novozym 435) & cotton seed oil & 50 & 24 & 97 & 278 \\
\hline Candida antarctica (Novozym 435) & rapeseed oil & 35 & 12 & 95 & 279 \\
\hline Candida sp. $99-125$ & soybean oil & 40 & 24 & 98.8 & 280 \\
\hline Pseudomonas fluorescens & sunflower oil & 40 & 48 & 91 & 281 \\
\hline Candida antarctica (Novozym 435) & sunflower oil & 50 & 15 & 97 & 282 \\
\hline Lipozyme IM-77 & soybean oil & 36.5 & 6.3 & 92.2 & 283 \\
\hline PS 30 lipase & palm oil ${ }^{\mathrm{a}}$ & 40 & 8 & 72.0 & 284 \\
\hline E. aerogenes lipase & jatropha oil & 55 & 48 & 94.0 & 285 \\
\hline P. fluorescens lipase & soybean oil & 35 & 90 & 80.0 & 286 \\
\hline IM M. miehei lipase & soybean oil ${ }^{\mathrm{a}}$ & 35 & 8 & 95.6 & 287 \\
\hline IM B. cepacia lipase & palm oil & 30 & 72 & 100 & 288 \\
\hline Candida rugosa & soybean oil & 35 & 30 & 87.0 & 289 \\
\hline Rhizopus oryzae & jatropha curcas & 30 & 60 & 80.0 & 290 \\
\hline Penicillium expansum & corn oil & 40 & 24 & 86.0 & 291 \\
\hline Geotrichum sp. & waste cooking oil & 50 & 4 & 85.0 & 292 \\
\hline Thermomyces lanuginose & crude palm oil & 40 & 4 & 96.2 & 293 \\
\hline R. miehei lipase & sunflower oil & 40 & 48 & 95.5 & 294 \\
\hline
\end{tabular}

${ }^{a}$ Reaction with ethanol. 
those disadvantages. For instance, we can refer to the hydro-esterification process, which is a good alternative process for reducing costs related to the separation step. Hydro-esterification is a process that allows the use of any fatty raw material, mainly with high contents of free fatty acids and water. This process is divided in two consecutive steps, hydrolysis followed by esterification. The hydrolysis step consists of chemical reaction between oil and water, producing glycerine and fatty acids. After hydrolysis, the fatty acids are esterified with alcohol (methanol or ethanol), resulting biodiesel in high purity. ${ }^{300}$ Another alternative is the simultaneous esterification and transesterification of vegetable oils with high content of free fatty acid using heterogeneous acid catalysts. These studies have been mentioned in detail on section 3 .

The use of sonication during the transesterification and esterification reactions for producing biodiesel has also been explored. The ultrasound-assisted process not only accelerates the reaction rate but also favors the miscibility between oil and methanol, decreasing the amount of catalyst needed for the reaction. Malek et al. ${ }^{301}$ published a review containing a number of studies with this technology. The use of microwave energy is also worth mentioning. The short reaction time is one of its biggest advantages. On the other hand, this technology cannot be easily scaled-up. There are reviews focusing specifically on the microwaveassisted transesterification processes using homogeneous and heterogeneous catalysts for biodiesel production. ${ }^{302}$ The results achieved from the use of intensification technologies have been well documented in several reviews available in the literature, which also present advantages, disadvantages and the current status of these technologies. ${ }^{303}$ Different reactor technologies for biodiesel production are also discussed in detail by Tabatabaei et al. ${ }^{304}$

Another alternative that can be used to produce biodiesel are processes at supercritical conditions. Supercritical fluid has been receiving a special attention in different types of processes due to its unique properties. The change of the fluid properties when within supercritical state is directly related to the density and its high compressibility. ${ }^{305}$ This difference of density reflects in the fluid coefficient of diffusivity, making the mass transfer easier in the supercritical medium. Besides that, the reaching of gases some properties such as surface tension and low viscosity, promote better dynamic characteristics and greater penetrability for the supercritical fluid.

The use of supercritical conditions in the biodiesel production can occur both in the alcohol used to produce the esters and through the addition of co-solvents in order to reduce significantly the operating conditions. The supercritical alcohol can form a single phase in contrast to the two-phase of oil/alcohol mixture at ambient condition. This is due to a decrease of the alcohol dielectric constant at supercritical condition. The most commonly used alcohols in conventional biodiesel, methanol $\left(240^{\circ} \mathrm{C}\right.$ and 78.7 bar $)$ and ethanol $\left(243^{\circ} \mathrm{C}\right.$ and 63.8 bar) production methods have very similar physical characteristics in the supercritical condition. ${ }^{306}$

The addition of a co-solvent reduces the interfacial tension and promotes better contact between the reactant molecules. Recent studies mainly use water or $\mathrm{CO}_{2}$ as cosolvent to eliminate the use of the catalyst in the process of biodiesel synthesis. ${ }^{307}$ Carbon dioxide offers a plenty of advantages as it is inert, non-toxic, non-polar and does not require very high pressure and temperature conditions to reach its supercritical state $\left(31\right.$ bar and $73.8^{\circ} \mathrm{C}$ ). So, it can be used for replacing a non-polar solvent without promoting undesired side reactions of oxy-reductions or breakdown of molecules. ${ }^{308}$

Recently, Jafari et al. ${ }^{309}$ directly converted wet microalgae biomass impregnated with ethanol in biodiesel using supercritical carbon dioxide. The lipid extraction and the transesterification process occurred simultaneously in a single step.

The use of supercritical medium offers a shorter residence time and higher purity of both products, biodiesel and glycerine, compared to those produced via conventional transesterification or hydro-esterification processes. Nevertheless, the supercritical process requires a higher operating condition. In this process, more robust equipment is necessary to support operating conditions of high pressures. Therefore, the biodiesel production by the supercritical route is still a laboratory condition, economically unfeasible, due to the costs of the process, either by the cost of the equipment to resist high temperatures and pressures, or by the cost of energy.

\subsection{Transesterification in supercritical conditions}

Transesterification is the traditional biodiesel production process. Therefore, the studies using supercritical conditions are mostly directed towards to this technological route.

According Dermibas, ${ }^{310}$ Saka and Kusdiana ${ }^{311}$ and Dermibas, ${ }^{312}$ transesterification with supercritical methanol requires less reaction time to reach high methyl ester conversions, simplifying subsequent product separation steps, since no catalysts were added. The authors have used different sources of vegetable oils for developing both a catalytic transesterification process and a supercritical methanol transesterification process with the same objective of increasing the alcohol solubility in oil. Even though the reactions using supercritical methanol result in a shorter 
residence time in the reactor and simplify the separating biodiesel step, it still requires high molar ratios of alcoholto-oil to achieve good conversions. In addition, the high temperature and pressure conditions bring a high cost of production and high initial investment. ${ }^{312}$

In order to reduce the operational conditions of the alcohol in supercritical medium, studies ${ }^{313}$ have added a co-solvent into the process, for achieving smoother critical conditions than it would have by using pure alcohol. Thus, the transesterification reaction can be performed under milder conditions, but still preserving the desired solubility between alcohol and oil. In this context, co-solvents such as carbon dioxide, hexane, propane and nitrogen were tested. ${ }^{313}$ On the other hand, in the biodiesel production, the addition of supercritical $\mathrm{CO}_{2}$ to the reaction medium has been highlighted in recent years as the most viable and interesting addition to this process.

Alves $^{299}$ and Maçaira et al. ${ }^{314}$ carried out experiments using heterogeneous catalyst to perform methyl transesterification in the presence of $\mathrm{CO}_{2}$. The authors obtained a good conversion rate of triacylglycerides to methyl esters. The experiments carried out by Alves ${ }^{299}$ were in the presence of zinc aluminate as a heterogeneous catalyst. These experiments were conducted with and without supercritical $\mathrm{CO}_{2}$ in order to evaluate each route separately. The results indicated the best reaction yields were obtained for methyl transesterification with supercritical $\mathrm{CO}_{2}$ (96.5\% with $30 \mathrm{~min}$ residence time). Using supercritical $\mathrm{CO}_{2}$ as co-solvent demonstrated that it is an alternative to overcome solubility and reactional homogeneity problems.

\subsection{Esterification in supercritical conditions}

The esterification reaction is the second step of the hydrothermal production process. The first reaction step is the hydrolysis. The esterification is commonly conducted when the raw material has a high acidity level, resulted from the presence of free fatty acids in the oil and/or fat. This reaction is responsible for ensuring the predominance of free fatty acids when the raw material is not yet completely converted. As in the transesterification process, esterification can also be conducted in the presence of acidic or alkaline, homogeneous or heterogeneous catalysts, and may or may not be associated with supercritical conditions in the process. ${ }^{306}$

In recent years, some authors have published the use of supercritical conditions to produce biodiesel via esterification. Alenezi et al. ${ }^{315}$ and $\mathrm{Koh}^{316}$ performed esterification experiments using supercritical methanol with temperatures ranging from 250 to $320^{\circ} \mathrm{C}$. In both studies, the authors report the strong influence of temperature and alcohol-to-oil molar ratio, whose increase leads to a better reaction yield. $\mathrm{Koh}^{316}$ had also noticed that the quality of the raw material does not influence the process and high conversions are reached in a short time for methanol and ethanol.

Tsai et al. ${ }^{317}$ conducted supercritical methanol experiments using carbon dioxide as co-solvent aiming to improve the yield of biodiesel production reactions. Therefore, as in transesterification, it is observed the use of supercritical alcohol modifies the esterification reaction performance. Although eliminating the catalyst separation subsequent steps, this process needs higher temperature and pressure operating conditions and higher amount of alcohol. Within the context of esterification by enzymatic catalysis, the addition of supercritical carbon dioxide also brings considerable improvements in results. ${ }^{318}$

\section{Additives for Blended and Unblended Bio- diesel}

Biodiesel is a renewable fuel which has been proposed as a viable alternative for partial diesel replacement by possibly reducing engine emissions and providing greater lubrication. However, biodiesel has some disadvantages. Among them, we should point the low stability to oxidation and biodegradation as main disadvantages. The maintenance of oxidative stability and the inhibition of microbial growth in biodiesel are extremely important for the biofuel market, both in terms of preserving its quality and the saved costs involved. Oxidative stability has been partly maintained through the addition of synthetic antioxidants originally developed for food products. In addition to increasing the biofuel costs, these products compromise the "green fuel seal".

Some countries are already adding biocides to biodiesel as well. This is derived from studies ${ }^{319}$ performed for evaluating the degradation of methyl ester mixture caused by microorganisms. However, there are quite a few studies specifically reporting the performance of new compounds acting as biocides. Additionally, biodiesel is hygroscopic and the amount of water absorbed acts directly on the corrosion of the metallic materials which it comes into contact. Regarding that, there also are quite a few studies involving the addition of corrosion inhibitors to this biofuel. Following, we discuss in more detail biodiesel additives.

\subsection{Antioxidant additives}

A strategy widely discussed in the literature to overcome the biodiesel low oxidative stability is the use of antioxidant additives. Additives are substances added 
to the fuel to improve their properties. In the case of the antioxidant additives, they act by preventing or retarding the biodiesel degradation, by donating an electron or hydrogen to the free radicals to neutralize the oxidation reaction. Thus, it avoids the formation of insoluble gums and sediments which increase biodiesel viscosity, may clog fuel filters or make deposits in the fuel injector. This should also be avoided in order to improve engine's functioning. ${ }^{320}$

The importance of antioxidant additives is critically discussed in a number of reviews published about this subject from 2005 to 2020 . One of the first reviews was published by Dunn in $2008 .{ }^{321}$ The author summarized the research progress in the development of effective antioxidants for use in biodiesel from soybean oil, rapeseed oil, used cooking oil, tallow and palm oil. ${ }^{321}$ Several authors have published reviews on the oxidative stability of biodiesel, such as Knothe, ${ }^{322}$ Jain and Sharma, ${ }^{22}$ Bannister et al.,${ }^{323}$ Pullen and Saeed, ${ }^{25}$ Fattah et al., ${ }^{324}$ Yaakob et al.,${ }^{325}$ Angelovic et al. ${ }^{326}$ Kumar, ${ }^{327}$ Agarwal et al..$^{328}$ and Varatharajan and Pushparani. ${ }^{320}$ In addition to the effects of antioxidants on the biodiesel oxidative stability, the most recent reviews also discuss the impact of these additives on performance, combustion and emission of vehicles. ${ }^{329}$ The antioxidant additives are divided into two groups: synthetic additives and additives from natural sources. In turn, the synthetic additives are sequentially subdivided into usual synthetic antioxidants, analogues and/or derivatives from the usual synthetic antioxidants and structurally different substances, which do not fall into the two previous classifications.

\subsubsection{Usual synthetic antioxidants}

The synthetic antioxidants usually added to commercial biodiesel generally are phenolic derivatives that exhibit high antioxidant activity. Those phenolic compounds act by stabilizing the radical generated in the oxidation reactions by the aromatic ring resonance, thus interrupting the free radical propagation reactions. These antioxidants are widely used in vegetable oils sold in the food market. ${ }^{330}$ For instance, BHT (butylated hydroxytoluene), TBHQ (tertbutylhydroxyquinone), PG (propyl gallate), PY (pyrogallol) and BHA (butylated hydroxyanisole) are the most used ones. Their chemical structures are presented in Figure 9.<smiles>CC(C)(C)c1cc(O)ccc1O</smiles>

TBHQ

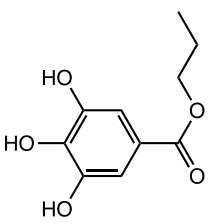

PG<smiles>Cc1cc(C(C)(C)C)c(O)c(C(C)(C)C)c1</smiles>

BHT<smiles>Oc1cccc(O)c1O</smiles>

PY<smiles>CC(C)(C)c1cc(O)cc(C(C)(C)C)c1O</smiles>

DTBHQ

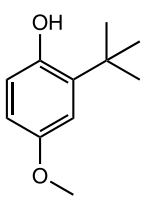

BHA
Figure 9. Chemical structures of usual synthetic antioxidant additives.

These antioxidants have been evaluated in several studies on biodiesel from different raw materials. The most commonly used biodiesels were those derived from soybean oil, ${ }^{331,332}$ sunflower oil,, ${ }^{332-336}$ and palm oil. ${ }^{333,337}$ The most recent publications have already started to pay attention in evaluating the effect of these antioxidants on the emissions, combustion and performance studies. ${ }^{338-357}$ In addition to these properties, conventional antioxidants have also been evaluated for antimicrobial activity. Beker et al. ${ }^{358}$ evaluated the effect of BHT and TBHQ antioxidants on the growth of microorganisms in soybean biodiesel. Dodos et al. ${ }^{359}$ evaluated the microbial action of synthetic and natural additives in soybean and olive biodiesels.

5.1.2. Analogues and/or derivatives from usual synthetic antioxidants-phenolic compounds

Most of the new antioxidant candidates are derived from commercially available antioxidant additives. There are commercial products which can be considered derivatives from the usual antioxidants. Two examples are Ionol, ${ }^{339,360-364}$ which is a mixture of phenolic compounds, and Vulkanox or BPH (2,2'-methylenebis(6-tert-butyl-4methylphenol)). ${ }^{339,342,365,366}$ The chemical structures of these components are presented in Figure 10.

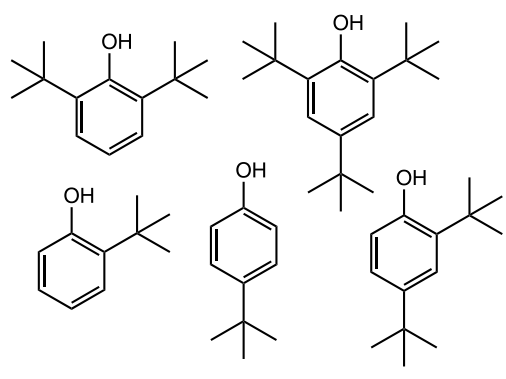

Ionol BF 200

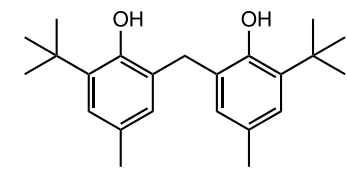

Vulkanox BKF or BPH

Figure 10. Constituents of the Ionol and BPH products derived from conventional synthetic additives. 
Li et al.$^{367}$ synthesized a number of gallic acid-derived esters with different short-chain alcohols. Their antioxidant effects were evaluated in relation to Jatropha curcas L. seed oil biodiesel using the Rancimat method. The structures are shown in Figure 11. Singh et al. ${ }^{368-370}$ published a sequence of three studies which they synthesized BHT (2,6-di-tertbutyl-4-methylphenol) derivatives. The BHT derivatives chemical structures are presented in Figure 12.

Muniz-Wypych et al. ${ }^{371}$ proposed new phenolic antioxidant additives derived from alkyl oleates (Figure 13).
This class of compounds is more soluble in biodiesel and showed to be very promising to enhance methyl rapeseed biodiesel oxidative stability.

\subsubsection{Unconventional synthetic antioxidants-non-phenolic compounds}

The group of so-called structurally different substances (non-conventional synthetic additives) is mainly composed with nitrogen compounds. Among them, the best known species are DPPD ( $N$ '-phenylbenzene-

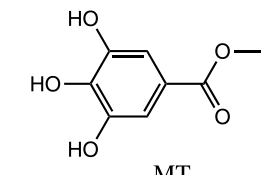

methyl3,4,5-trihydroxybenzoate

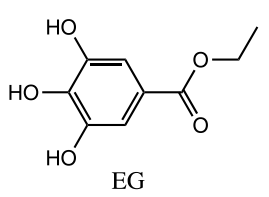

ethyl gallate
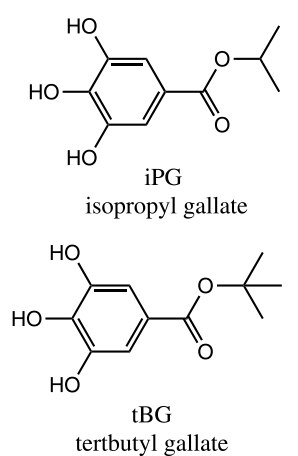

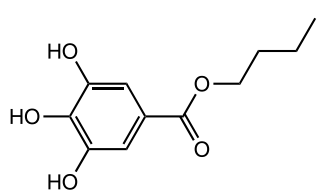

BG

n-butyl gallate

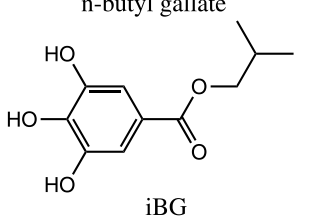

isobutyl gallate

Figure 11. Substances derived from gallic acid.<smiles>CC(C)(C)c1cc(COC(=O)c2cc(C(=O)OCc3cc(C(=O)OCc4cc(C(C)(C)C)c(O)c(C(C)(C)C)c4)c(C(=O)OCc4cc(C(C)(C)C)c(O)c(C(C)(C)C)c4)c(C(=O)OCc4cc(C(C)(C)C)c(O)c(C(C)(C)C)c4)c3)cc(C(=O)OCc3cc(C(C)(C)C)c(O)c(C(C)(C)C)c3)c2)cc(C(C)(C)C)c1O</smiles><smiles>CC(C)(C)c1cc(/C=N\CNc2nc(/N=C/c3cc(C(C)(C)C)c(O)c(C(C)(C)C)c3)nc(NCCNc3nc(/N=C/c4cc(C(C)(C)C)c(O)c(C(C)(C)C)c4)nc(/N=C/c4cc(C(C)(C)C)c(O)c(C(C)(C)C)c4)n3)n2)cc(C(C)(C)C)c1O</smiles>

Figure 12. BHT synthetic derivatives. 
<smiles>CCCC(NC(=O)OC)c1ccc(O)c(O)c1</smiles>

$1 \mathrm{MB3}$<smiles>CCCC(NC(=O)OC)c1cc(O)ccc1O</smiles>

$2 \mathrm{MB3}$<smiles>CCOC(=O)C(CC=[V])c1ccc(O)c(O)c1</smiles>

3 MB3<smiles>CCOC(=O)C(C)Cc1cc(O)ccc1O</smiles>

$4 \mathrm{MB3}$
Figure 13. New phenolic derivatives obtained by Muniz-Wypych et al. ${ }^{371}$ from the reaction with alkyl oleates.

\section{1,4-diamine), ${ }^{332,339,341,372-382}$ NPPD ( $N, N$ '-diphenyl-} 1,4-phenylenediamine), ${ }^{341,372,373,378,381,382}$ succinimide

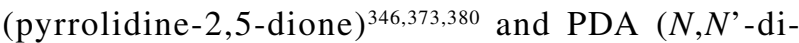
sec-butylbenzene-1,4-diamine)..$^{365,383-387}$ The structures of these compounds are presented on Figure 14. Bär et al. ${ }^{388,389}$ studied the antioxidant activity of a series of hydrazide derivatives. Figure 15 presents the hydrazide derivatives evaluated as antioxidants.

Dodson et al. ${ }^{390}$ synthesized new glycerol acetals from aromatic aldehydes (Figure 16), which their antioxidant activities were quantified through a standard procedure using diphenyl-picryl-hydrazine radical (DPPH·) method. The main objective of this study was to investigate a

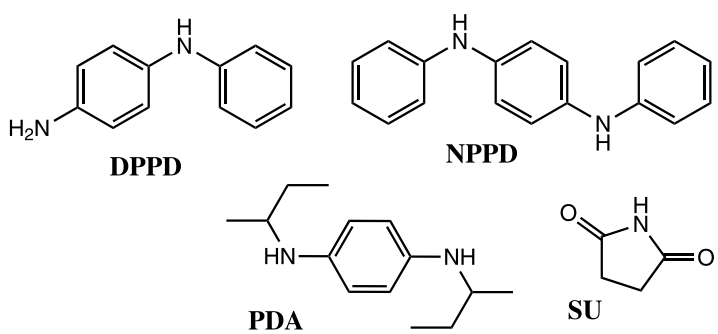

Figure 14. Structures of some non-conventional synthetic additives.

potential application for glycerol, which is a secondary product from biodiesel synthesis.

El-Boulifi et al. ${ }^{391}$ obtained kojic acid ricinoleate by lipase-catalyzed esterification in a solvent-free system. The addition of the new kojic acid derivative (Figure 17) improved the rapeseed biodiesel oxidation stability.

Schirmann et al. ${ }^{392}$ synthesized three dimers of 2,6-dimethoxyphenol through laccase-catalyzed oxidative coupling reactions (Figure 18). The product 3,3',5,5'-tetramethoxybiphenyl-4,4'-diol (dimer II) was evaluated as antioxidant candidate for soybean biodiesel and showed an efficacy similar to the commercial antioxidant BHT. ${ }^{393}$ Sui and $\mathrm{Li}^{394}$ investigated the antioxidant effect of tetraethylenepentamine on rapeseed biodiesel oxidation resistance at different concentrations. The use of $2.1 \%$ of the additive increased the induction time in the Rancimat test by more than 10 times compared to pure biodiesel. Recently, Figueredo et al. ${ }^{395}$ tested the antioxidant activity

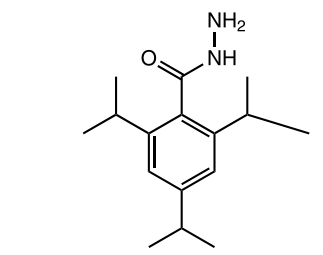

2,4,6-tris-isopropylbenzoic hydrazide

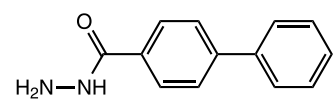

Biphenyl-4-carboxylic hydrazide<smiles>CC(C)C(=O)NN</smiles>

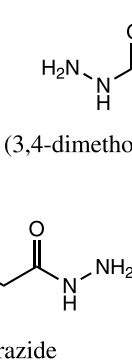<smiles>NNC(=O)Cc1ccccc1</smiles><smiles>CC(C)(C)C(=O)NN</smiles>

pivalic hydrazide

Isobutyric hydrazide<smiles>CC(=O)NNC(=O)CCCCC(=O)NN</smiles>
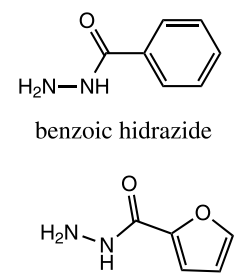

2-furoic hydrazide<smiles>COc1cc(CC(=O)NN)ccc1O</smiles><smiles>CCCC(=O)NN</smiles><smiles>CC(C)(C)OC(=O)NCC(=O)NN</smiles>

$n$-butyric hydrazide

boc-glycine hydrazide

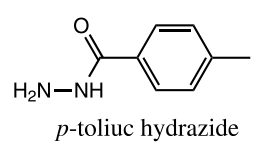

Figure 15. Hydrazide derivatives evaluated as antioxidants. 

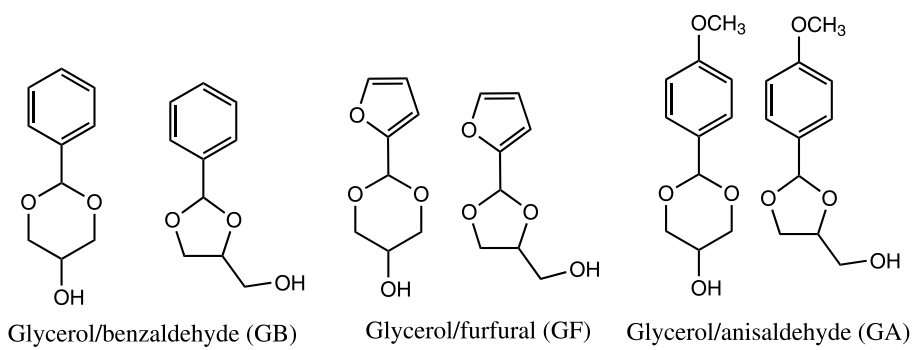

Figure 16. Chemical structure of antioxidant candidates derived from glycerol.<smiles>CCCCCCC/C=C/CC(O)CCCCCCC(=O)OCc1cc(=O)c(O)co1</smiles>

Figure 17. Structure of kojic acid ricinoleate.<smiles>COc1cc(OC)c(Oc2cc(OC)c(O)c(OC)c2)cc1O</smiles>

(I)<smiles>COc1cc(-c2cc(OC)c(O)c(OC)c2)cc(OC)c1O</smiles>

(II)<smiles>COC1=CC(=C2C=C(OC)C(=O)C(OC)=C2)C=C(OC)C1=O</smiles>

(III)
Figure 18. Coupled oxidative products of 2,6-dimethoxyphenol catalyzed by laccase.

of $N, N^{\prime}$-disec-butyl-p-phenylenediamine in babassu biodiesel by the Rancimat method and differential scanning calorimetry. The results showed a significant improvement in the biodiesel oxidative stability.

\subsubsection{Natural antioxidants}

Most vegetable oils used to produce biodiesel have in their composition natural antioxidants which are removed during the process of transesterification or esterification. In the literature, there are several studies applying these antioxidants in the exogenous form, as it is the case of $\alpha$-tocopherol ${ }^{384,396-407}$ and gossypol (substance found in cottonseed oil) (Figure 19). ${ }^{399,408}$ Naturally occurring acids commonly used in the cosmetic industry as antioxidants were also evaluated for their action on biodiesel. In this context, it could be highlighted ascorbic acid, ${ }^{374,396,402,403,409-411}$ caffeic acid, ${ }^{359,398,400,412-414}$ ferulic acid,,$^{398,400,413}$ and gallic acid (Figure 19). ${ }^{398,415}$

Several plant extracts were also used to improve the biodiesel oxidative stability. ${ }^{416-420}$ The most reported in the literature are the extracts of rosemary leaves ${ }^{421-426}$ basil leaves, ${ }^{42,423,427}$ oregano leaves, ${ }^{422,424,425,427}$ and green tea. ${ }^{401,428}$

Some authors also have been studying the antioxidant potential of co-products from the pulp industry, the

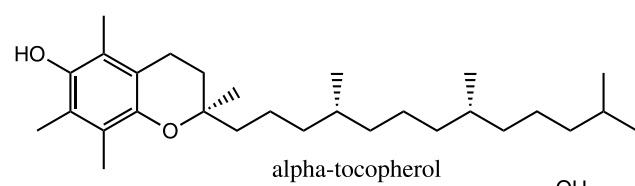<smiles>Cc1cc2c(C(C)C)c(O)c(O)c(C=O)c2c(O)c1-c1c(C)cc2c(C(C)C)c(O)c(O)c(C=O)c2c1O</smiles><smiles>O=C1O[C@H]([C@@H](O)CO)C(O)=C1O</smiles>

ascorbic acid<smiles>O=C(O)/C=C/c1ccc(O)c(O)c1</smiles><smiles>COc1cc(/C=C/C(=O)O)ccc1O</smiles>

Figure 19. Chemical structures of natural antioxidants.

lignocellulosic bio-oils, ${ }^{429-433}$ and cashew nut processing industry (cashew nut shell liquid (CNSL)), ${ }^{434-437}$ which is composed by a mixture of alkylphenols.

Regarding to CNSL, its isolated constituents as well as the synthetic derivatives of these alkylphenols have also been evaluated as antioxidant for biodiesel. Rodrigues et al. ${ }^{438}$ evaluated the antioxidant activity of hydrogenated cardanol. In turn, Lomonaco et al. ${ }^{439}$ synthesized and evaluated phosphorylated compounds derived from cardanol. Maia et al. ${ }^{440}$ evaluated the antioxidant activity of saturated and unsaturated tert-butylated cardanol. dos Santos et al. ${ }^{441}$ submitted a portion of technical CNSL to an electrolytic process, which resulted in a product with improved antioxidant activity. According to the authors, the electrolysis process may lead to the formation of dimers or oligomers by reaction between phenols in technical CNSL. And these compounds may be the responsible for the observed higher oxidative stability. Liu et al. ${ }^{442}$ synthesized cardanol epoxide, being the pioneers in the cardanol alkyl chain transformation. Recently, Costa et al. ${ }^{443}$ evaluated the antioxidant potential and thermal stability of CNSL and cardanols oxygenated derivatives. They synthesized five novel oxygenated derivatives. From those derivatives 
the one obtained from the cardanol epoxide hydrolysis increased the commercial biodiesel oxidative stability by three times. Some cardanol synthetic derivatives evaluated as antioxidant are presented in Figure 20.

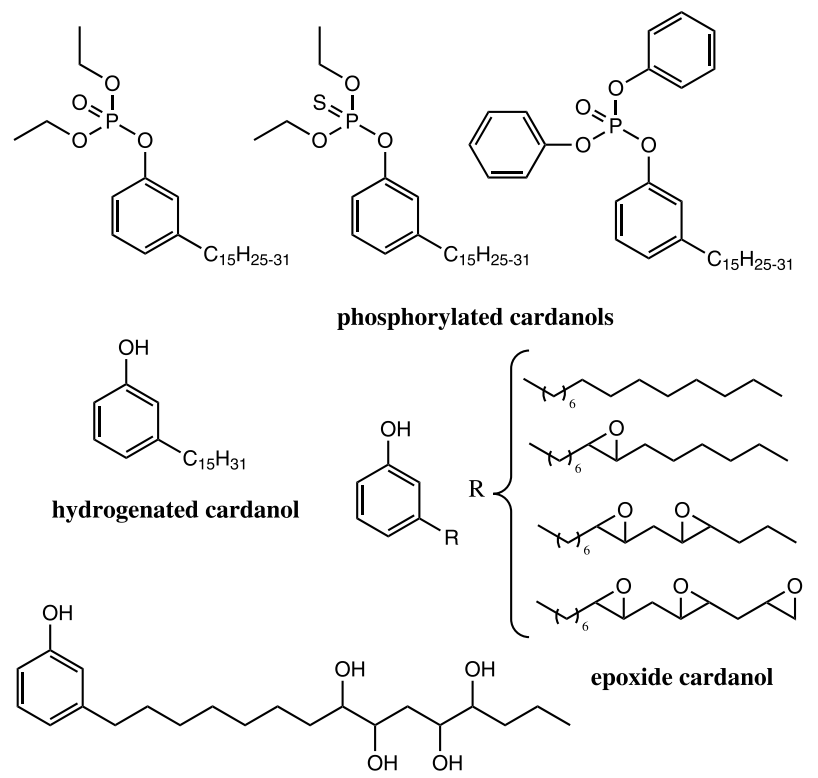

cardanols hydrolysis product

Figure 20. Chemical structures of some cardanol synthetic derivatives evaluated as antioxidants for biodiesel.

\subsection{Biocide additives}

Microbial contamination is also one of the important problems associated with fuel storage. Indeed, the proliferation of fungi and bacteria are more common in diesel systems. ${ }^{444}$ Microorganisms present in biodiesel/ diesel blends are likely to affect the overall fuel quality due to their metabolites, which act accelerating fuel deterioration. ${ }^{319}$ This kind of biomass can damage the engine fuel injection system by clogging pipes and filters as well as by adhering a biofilm onto material surfaces (then forming a type of fouling). In addition, it may lead to storage tanks corrosion, known as microbiologically influenced corrosion (MIC). ${ }^{445,446}$ The fuel, used as a source of nutrients together to its water content, becomes a propitious environment for microbial growth. In this way, a practice of performing periodic drainage of accumulated water at the bottom tanks is an important method of prevention of microbial activity. In addition, the adoption of reduced fuel storage times could also prevent fuel contamination. The literature has been addressing the development of alternative methods for prevention of microbial growth. It has been proposed, for instance, treatment with ultraviolet radiation, safe use of sonication, addition of hydrogen peroxide and biocides. ${ }^{447}$
Since the beginning biodiesel emerged as a renewable fuel and the fact of being biodegradable as one of the main advantages. The biodegradability of fossil diesel increases with the addition of biodiesel, which is a gain in the case of accidental spill of biodiesel/diesel blends. ${ }^{448}$ Accordingly, the use of biodiesel to remediate fuel contaminated areas was considered since the operation is affordable and it does not require high technology. ${ }^{449}$ However, soon after its implementation, what previously was considered an advantage, became a concern. The accumulation of deposits in diesel storage tanks has considerably increased, as well as the need for diesel vehicles maintenance. For instance, the replacement of fuel filters and the cleaning of injection system started to be done at shorter intervals. The main cause why this was happening is the substantial increase of the biomass growth. Furthermore, biodiesel is 30 times more hygroscopic than mineral diesel. Therefore, keeping the water content to a minimum in the biodiesel/diesel blends storage tanks becomes essential. And exercise the water content control in the pure biodiesel (B100) storage tanks is an even more difficult task. Within this context, one plausible strategy to prevent microbial contamination is the addition of biocides to both blended and unblended biodiesel.

In 2013, Passman ${ }^{319}$ provided an excellent survey about microbial contamination and its control in fuels and fuel systems. The review reports about biodeterioration of diesel and biodiesel fuels, factors contributing for microorganism's contamination and proliferation through fuel storage tanks and engine fuel systems, methods of microbial contamination control, and decontamination practices, among others. In the following year, Jakeria et al. ${ }^{450}$ reviewed different factors affecting biodiesel stability, including microbial growth. They comment about the degradation mechanism of fatty acid methyl esters by microorganisms, known as cometabolic biodegradation, and the reasons why biodiesel and biodiesel/ diesel blends degrade faster than diesel. In our review, we discuss three segments related to microbial growth. The first part presents a brief survey of the microorganisms identified in biodiesel/diesel blends and pure biodiesel storage tanks. The second part describes some studies regarding the evaluation of favorable conditions for microbial growth. This knowledge is important for studying ways to control the growth of these microorganisms. The last part presents products that have been commercially added as biocide in biodiesel/diesel blends and in pure biodiesel, as well as products tested for this purpose.

\subsubsection{Identification of microorganisms content in biodiesel and biodiesel/diesel blends storage tanks}

Studies have shown, as it happens for diesel, that biodiesel biodegradation is performed by either bacteria, 
yeasts and/or fungi. The isolation of the microorganisms present in the sludge from biodiesel and biodiesel/diesel blends requires the use of specific culture media for different microorganisms' growth. ${ }^{451}$ For instance, potato dextrin agar is used to detect potential fungi, peptone casein agar and tryptic soy agar usually are employed for detecting bacteria. In addition, malt extract agar is used to detect possible yeasts and anaerobic agar is specifically used to grow anaerobic microorganisms. In turn, the identification of the microorganism species is based on a set of morphological, biochemical, physiological and molecular evidences of the isolates. Table 9 presents some microorganisms isolated in sludge generated from biodiesel/diesel blend or pure biodiesel.
5.2.2. Susceptibility of microorganism growth in biodiesel and biodiesel/diesel blends

Studies involving the evaluation of microbial growth conditions on biodiesel from different raw materials are found in the literature. Some examples are cited on Table 10 and more details are found in their respective references. Some of them used microorganisms isolated from contaminated biodiesel and biodiesel/diesel blends storage systems, as indicated in the table.

\subsubsection{Biocide additives for biodiesel and biodiesel/diesel blends}

There are three biocides approved and registered by U.S. Military Specification as diesel fuel biocides. ${ }^{460}$

Table 9. Microorganisms isolated in sludge generated from biodiesel/diesel blend or pure biodiesel

\begin{tabular}{|c|c|c|c|c|}
\hline Microorganism & Strain or genus & Biodiesel raw material & $\mathrm{BX}$ & Reference \\
\hline Bacteria & $\begin{array}{c}\text { Klebsiella oxytoca } \\
\text { Klebsiella nov. sp. } \\
\text { Staphylococcus epidermidis }\end{array}$ & canola oil & $\mathrm{B} 5$ and $\mathrm{B} 10$ & 451 \\
\hline Bacteria & $\begin{array}{l}\text { Pseudomonas, Comamonas, Burkholderia } \\
\text { genera, among others }\end{array}$ & $\begin{array}{l}80 \% \text { soybean oil/ } \\
20 \% \text { beef tallow }\end{array}$ & B10 & 445 \\
\hline Bacteria & $\begin{array}{c}\text { Micrococcus luteus } \\
\text { Microbacterium } \mathrm{sp} . \\
\text { Cellulomonas } \mathrm{sp} . \\
\text { Curtobacterium sp. } \\
\text { Bacillus megaterium } \\
\text { Bacillus } \text { sp. } \\
\text { Bacillus pumilus } \\
\end{array}$ & soybean oil & B100 & 452 \\
\hline Fungi & $\begin{array}{c}\text { Xylariales } \mathrm{sp} . \\
\text { Penicillium citrinum } \\
\text { Penicillium simplicissimum } \\
\text { Penicillium corylophilum } \\
\text { Hypocreales } \mathrm{sp} .\end{array}$ & soybean oil & B100 & 452 \\
\hline
\end{tabular}

Table 10. Data from susceptibility of microorganism growth in biodiesel or biodiesel/diesel blend

\begin{tabular}{|c|c|c|c|c|}
\hline Microorganism & Specie, strain or genus & Biodiesel raw material & $\mathrm{BX}$ & Reference \\
\hline Fungi and bacteria & microorganisms from soil & rapeseed oil & $\mathrm{B} 5, \mathrm{~B} 20, \mathrm{~B} 100$ & 453 \\
\hline Fungi and yeasts ${ }^{\mathrm{a}}$ & $\begin{array}{c}\text { Aspergillus fumigatus, } \\
\text { Candida silvicola } \\
\text { Paecilomyces sp., Rhodotorula sp. }\end{array}$ & soybean oil & $\mathrm{B} 5, \mathrm{~B} 10, \mathrm{~B} 20, \mathrm{~B} 100$ & 454 \\
\hline Bacteria $^{a}$ & $\begin{array}{l}\text { methanogenic bacteria } \\
\text { sulfate-reducing bacteria } \\
\text { nitrate-reducing bacteria }\end{array}$ & animal fat & B5, B10, B20, B50, B100 & 455 \\
\hline Fungus & Pseudallescheria boydii & beef tallow & B100 & 456 \\
\hline Fungus & Pseudallescheria boydii & linseed, soybean and olive oil & B100 & 457 \\
\hline Fungus & Pichia anomala & soybean oil and beef tallow & B5, B100 & 458 \\
\hline Bacteria & Mycobacterium sp. & beef tallow & B5, B100 & 458 \\
\hline Bacteria & Tepidimonas sp. & soybean oil & B5, B100 & 458 \\
\hline Fungus & A. niger variety tubingensis & $\begin{array}{l}\text { soybean oil, beef tallow } \\
65 \% \text { soybean } / 35 \% \text { beef tallow, }\end{array}$ & B100 & 459 \\
\hline
\end{tabular}

${ }^{\mathrm{a}}$ Microorganisms isolated from biodiesel or biodiesel/diesel blends storage systems. BX $=\mathrm{X} \% \mathrm{v} \mathrm{v}^{-1}$ of biodiesel in diesel; B100 $=$ pure biodiesel. 
The first additive (DOB) consists of 2,2-oxybis(4,4,6-trimethyl-1,3,2-dioxaborinane) and 2,2-(1-methyltrimethylenedioxy)-bis-(4-methyl-1,3,2-dioxaborinane). The second biocide formulation (CMIT/MIT) is an isothiazolinone blend (5-chloro-2-methyl-4-isothiazolin3-one and 2-methyl-4-isothiazolin-3-one) and the third (NBM/ENDM) is a mixture of 4-(2-nitrobutyl)-morpholine and 4,4'-(2-ethyl-2-nitrotrimethylene)-dimorpholine. There is also a fourth product used for microbicidal fuel treatment, 3,3-methylenebis(5-methyloxazolidine), known as MBO. ${ }^{319}$ $\mathrm{MBO}$ can be purchased in its pure form or formulated in multifunctional additives which may contain different percentuals of this antimicrobial product. Their chemical structures are presented in Figure 21.
DOB
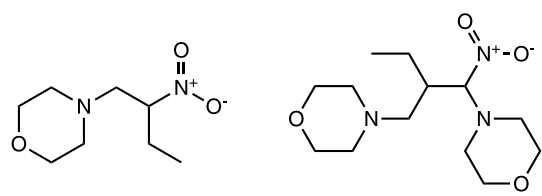

NBM/ENDM

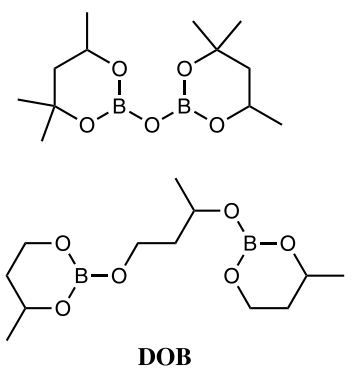

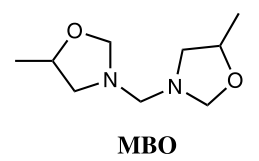

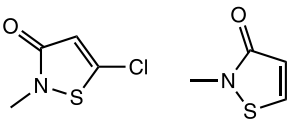

CMIT/MIT
Figure 21. Chemical structures of products used as a fuel-treatment biocide.

In the last years, some of these products have been studied by researchers from the Federal University of Rio Grande do Sul, Brazil. Zimmer et al. ${ }^{461}$ investigated the effectiveness of $\mathrm{MBO}$, using a multifunctional additive formulation for fuel which contains $50 \%$ of this biocide, and MIT/CMIT product, that contains $1.5 \%$ of active ingredient, in biodiesel (produced from $60 \%$ of soybean oil and $40 \%$ of beef tallow), low sulfur conventional diesel, B7 and B10 blends. The efficacy of both biocides was evaluated for 60 days using the fuel phase and two types of aqueous phase (natural bottomwater formed in a biodiesel/diesel blend and synthetic water with low, medium and high levels of contamination). A mix of uncharacterized microbial sludge obtained from different fuels (diesel, biodiesel and biodiesel/diesel blends) was used as inoculum. MIT/CMIT performed better in all conditions tested. The authors suggest the presence of other additives in the formulation is interfering negatively in the action of $\mathrm{MBO}$, since in previous studies pure $\mathrm{MBO}$ had performance comparable to MIT/CMIT.
Cazarolli et al..$^{457}$ evaluated the efficiency of $100 \%$ $\mathrm{MBO}, 8 \% \mathrm{MBO}, 50 \% \mathrm{MBO}$ and $100 \% \mathrm{NBM}$ in the control of Pseudallescheria boydii growth using the broth dilution method. According to the values of the minimum inhibitory concentration (MIC) and minimum biocide concentration (MBC), 100\% NBM was the most effective in containing growth and presented sporicidal action. The authors did not investigate the effect of the antimicrobial products on a biodiesel or biodiesel/diesel blend system inoculated with fungus. In the same year, Bücker et al. ${ }^{445}$ studied the effect of MBO in stored B10 with and without an inoculum derived from diesel sludge. The biodiesel used to prepare B10 blend was originated from soybean oil $(80 \%)$ and beef tallow (20\%). Pure active ingredient $(100 \% \mathrm{MBO})$ and an additive formulation containing $50 \%$ $\mathrm{MBO}$ were evaluated. The study revealed microbial growth was effectively controlled with the use of pure MBO in all experiments. The microbial number in the aqueous and oil phases was reduced using the formulation at $50 \% \mathrm{MBO}$ and the results indicated that $500 \mathrm{ppm}$ of this formulation led to fungistatic activity. The same additive formulation was used by Zimmer et al. ${ }^{462}$ to compare the microbial growth in a B10 blend stored under simulated conditions in laboratory scale $(250 \mathrm{~mL}$ microcosms) and field scale (20 L tanks). They used an uncharacterized microbial sludge obtained from biodiesel/diesel blend as inoculum. The results showed the condition often defined in the laboratory may demand adjustments under real situations.

\subsubsection{Evaluation of biocide candidates for pure biodiesel} and biodiesel/diesel blends

Despite the need to control microbial growth, there are few studies available in the literature specifically focusing on the development of biocide candidates for use in pure biodiesel and biodiesel/diesel blends. Meanwhile, some researchers have evaluated if antioxidant additives also have biocide action. Beker et al. ${ }^{358}$ evaluated the effect of the commercial antioxidants tert-butylhidroquinone (TBHQ) and butylated hydroxytoluene (BHT) on microorganisms isolated from diesel and biodiesel storage tanks (fungi Paecilomyces variotii, Pseudallescheria boydii and Candida guilliermondii, and the bacterium Bacillus pumilus). Firstly, the authors evaluated the minimum inhibitory concentration (MIC) of BHT and TBHQ using the broth dilution method. The experiment was also carried out with an uncharacterized inoculum prepared according to ASTM E1259463 using microbiological sludge from a contaminated tank. No antimicrobial effect was observed for BHT in all tested concentrations. In laboratory scale, the uncharacterized inoculum medium was added to soybean biodiesel containing different TBHQ 
concentrations. The vials were incubated for 45 days at $30{ }^{\circ} \mathrm{C}$. TBHQ appears to be neither a promoter nor an inhibitor of microbial growth in biodiesel under the conditions tested. Santos et al. ${ }^{464}$ tested the growth of the filamentous mold Paecilomyces variotii Bainier in presence of biodiesel added with curcumin and pyrocatechol. The study includes biodiesel from various fatty acid sources (waste frying oil, soybean oil, cottonseed oil, sesame oil, macaúba almond oil and microalgae oil). The experiments were carried out in Petri dishes containing solid Sabouraud dextrose agar incubated at $25^{\circ} \mathrm{C}$ for $48 \mathrm{~h}$. After this time, the plates were visually inspected for the presence of inhibition zones of fungal growth. The best fungistatic effect was observed in the presence of 0.1 to $0.5 \%\left(\mathrm{~m} \mathrm{~m}^{-1}\right)$ curcumin, depending on the biodiesel sample, and $1 \%\left(\mathrm{~m} \mathrm{~m}^{-1}\right)$ water.

Dodos et al. ${ }^{359}$ evaluated the antimicrobial activity of six synthetic phenolic antioxidants (butylated hydroxyanisole, BHA; butylated hydroxytoluene, BHT; tert-butyl hydroquinone, TBHQ; propyl gallate, PG; pyrogallol, PY; and tert-butyl catechol, TBC) and four natural phenolic antioxidants (caffeic acid, CFA; gentisic acid, GA; methyl catechol, MCT; and protocatechuic acid, PCA) in B100 and B7 blends from refined pomace olive oil and soybean oil. Initially, the ability of the phenolic additives to inhibit microbial growth was tested against Bacillus stearothermophilus, a Gram-positive bacterium, at $64{ }^{\circ} \mathrm{C}$ for $3.5 \mathrm{~h}$. TBHQ, PG, MCT and TBC were the most efficient in inhibiting the growth of Bacillus stearothermophilus in fatty acid methyl esters (FAME) from both refined pomace olive oil and soybean oil. BHA, BHT, GA and PCA did not show antibacterial activity under the conditions tested. $\mathrm{B} 7$ blends were treated with TBHQ, PG, MCT, TBC, PY and CFA. Only TBHQ, PG, MCT and TBC depicted antimicrobial action. In the second part of the study, the authors investigated the antimicrobial activity of the most active phenolic compounds in simulated diesel/biodiesel fuel storage conditions. The inoculum was prepared according to ASTM E1259 $9^{463}$ using the aqueous phase of a microbially contaminated commercial diesel. B100 and B7 blends were also treated with the commercially fuel biocide MBO for comparison. As expected, the MBO product practically eliminates the active microbial contamination in FAME from both vegetable oils tested. The microcosm was significantly suppressed in those containing TBHQ and MCT. In both B7 blends microcosms, the two catechol derivatives (MCT and TBC) proved to be more effective antimicrobial additives.

Recently, some studies have evaluated the biocide activity of triacylglyceride derivatives. The objective was to reveal potential additives from chemical modifications in the same raw material used for biodiesel production. Ramalho et al. ${ }^{465}$ synthesized an imine product via hydroformylation of the double bonds present in the hydrocarbon chain of soybean fatty acid methyl esters, followed by $n$-butylamine condensation. In other words, the authors synthesized biodiesel-based molecules whose antimicrobial activity was evaluated towards a set of fungi and bacteria commonly present in fuel storage tanks. The addition of 5\% of the imine product in soybean biodiesel presented positive antimicrobial activity in both agar diffusion test and antimicrobial susceptibility test, for fungi Candida krusei, Candida parapsilosis, Candida albicans, Aspergillus niger, Aspergillus fumigatus and Saccharomyces cerevisae, and for bacteria Escherichia coli, Bacillus subtillis and Staphylococcus aureus. Oliveira et al. ${ }^{466}$ tested the product of acetylation of epoxidized soybean biodiesel against three fungi species (Aspergillus fumigatus, Trichophyton rubrum and Microsporum canis) and four species of bacteria (Bacillus subtilis, Escherichia coli, Pseudomonas aeruginosa and Staphylococcus aureus). The antimicrobial activity was evaluated by agar diffusion test with soybean biodiesel containing 1 to $50 \%$ of the biocide candidate. According to the authors, this method is widely used in microbiology laboratories to select substances with potential antimicrobial activity for pharmacological areas. The acetylation product showed fungicidal activity to Trichophyton rubrum and Aspergillus fumigatus. Costa et al. ${ }^{467}$ synthesized nitrated derivatives using soybean oil as starting material. The products were evaluated against fungi and bacteria which have been isolated from biodiesel/diesel blends (fungi Aspergillus niger, Aspergillus fumigatus, Candida albicans and Saccharomyces cerevisiae; and bacteria Bacillus subtilis and Acinetobacter baumannii). None of the products inhibited the bacteria growth. Four nitrated derivatives presented modest fungicidal activity against $A$. niger and A. fumigatus. Three products derived from the vegetable oil (Figure 22). The chemical structures are represented

(a)

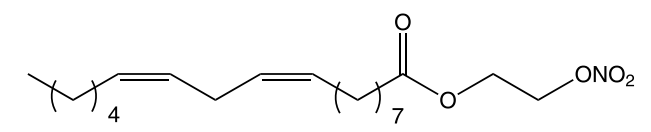

(b)

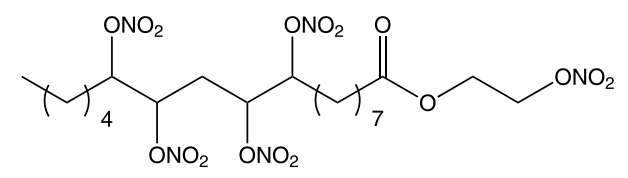

(c)

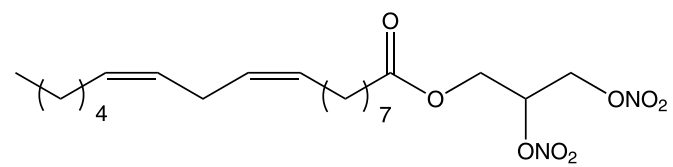

Figure 22. Derivatives from soybean oil with activity against $A$. niger and A. fumigatus. 
by linoleic chain, which is the major hydrocarbon chain of soybean triacylglycerides, for illustration. The fourth product is the pure nitrate of ethylene glycol linoleate.

\section{Emissions}

Estimates from the World Health Organization (WHO) state that 4.2 million people die every year due to the exposure to outdoor air pollution and $91 \%$ of world's population lives in places where the air quality is inappropriate, according to the WHO's guidelines. ${ }^{468}$ These deaths are mainly linked to chronicle diseases, such as pulmonary obstruction, but also lung cancer, cardiovascular diseases and acute respiratory infections in children. According to the WHO's report, worldwide ambient air pollution accounts for $29 \%$ of all deaths and disease from lung cancer, $17 \%$ of all deaths and disease from acute lower respiratory infection, $24 \%$ of all deaths from stroke, $25 \%$ of all deaths and disease from ischaemic heart disease and $43 \%$ of all deaths and disease from chronic obstructive pulmonary disease. ${ }^{468}$

Pollutants which play an important role for the air quality and public health issues include, amongst others, particulate matter (PM), nitrogen dioxide, ozone and sulfur dioxide. Regarding particulate matter, especially particles with a diameter $\leq 10 \mu \mathrm{m}\left(\mathrm{PM}_{10}\right)$ and fine particles with a diameter $\leq 2.5 \mu \mathrm{m}\left(\mathrm{PM}_{2.5}\right)$, it is prone to deeply penetrate in the lungs and bloodstream. Its composition may include, amongst other species, metals, sulfate, nitrates and black carbon, and normally it will play a role in the transportation of different kinds of toxic species adsorbed on its surface, such as organic compounds. In 2013, it was classified by the International Agency for Research on Cancer (IARC) as cause of lung cancer. ${ }^{469}$ According to the WHO, ${ }^{468}$ the effects of PM on health occur at levels of exposure currently present in urban and rural areas and in developed and developing countries. Furthermore, exposures in many fastdeveloping cities are even much higher than in developed cities of the same size.

Exhaust emissions from diesel burning contain hundreds of compounds, either in the gas or in the particulate phases, which are proved, or suspected to be carcinogenics. Representants of those exhausted species which may be cited are formaldehyde, acrolein, polycyclic aromatic hydrocarbons (PAHs), nitro-PAHs, benzene, and sulfate, among others. Besides, they also produce large amount of fine particulate matter $\left(\mathrm{PM}_{2.5}\right)$, which are able to go deep into respiratory systems and may cause different health-related endpoints. As a consequence, the use of alternative fuels is likely to contribute for reducing the health and environmental impacts of diesel emissions, and it has been extensively investigated.
In the last years, several researchers have as main objective the search for solutions which can help to mitigate the emissions of pollutants to the atmosphere. This scenario is not different with respect to emissions from the incomplete combustion process of diesel cycle engines. A lot of technologies have been developed and incorporated in diesel engines, in order to reduce pollutant emissions although there is a special attention in the application of alternative fuels which are not of fossil origin. Biodiesel is the main substitute for the diesel fuel because it does not require modifications to the diesel engine. Besides it may present several benefits, such as reduction of atmospheric pollutants emission and a greater cetane number, among others.

Through a brief research using the keyword "biodiesel emission" in scientific databases, it is possible to map a growing interest on the subject, given the number of papers that aimed at evaluating emissions from biodiesel use. In 2005, when the first article Biodiesel: An Overview ${ }^{15}$ was published, the number of publications on the subject was already significative. However, more than ten years later, this number has practically increased by 17 times. This demonstrates how significant and effective has been the employment of biodiesel/diesel blends, as a way to mitigate the emission of pollutants from the incomplete combustion of diesel engines.

When the focus of publications is evaluated (Figure 23), it is possible to observe that different parameters are considered in studies as possibly affecting the emissions, such as the use of a third fuel in a ternary mixture, as well as the main types of pollutant emitted, with focus on both regulated and non-regulated pollutants, due to their environment and health impacts. One topic addressed is related to the biodiesel source, since it can be produced either from edible or non-edible parts of different leguminous plants. In order to comply with the current regulations, regarding restrictions on diesel emissions, several technologies have been used. Meanwhile studies have been conducted in order to evaluate the impact of using biodiesel in different combinations to other fuels. Other parameters also evaluated are diesel engines performance (load and power) as well as the use of different types of fuel additives in order to improve fuel lubricity, cetane number, and processes of early oxidation, among others.

Investigations using ternary fuel mixtures containing biodiesel have focused on compounds which do not affect the biodiesel's miscibility in diesel fuel and if they may contribute for reducing pollutant emissions. Short chain alcohols (e.g., ethanol and $n$-butanol), ${ }^{470-473}$ ethers (2,5-dimethylfuran) $)^{472}$ and kerosene ${ }^{474}$ are examples of compounds which having been added in the fuel blends. 


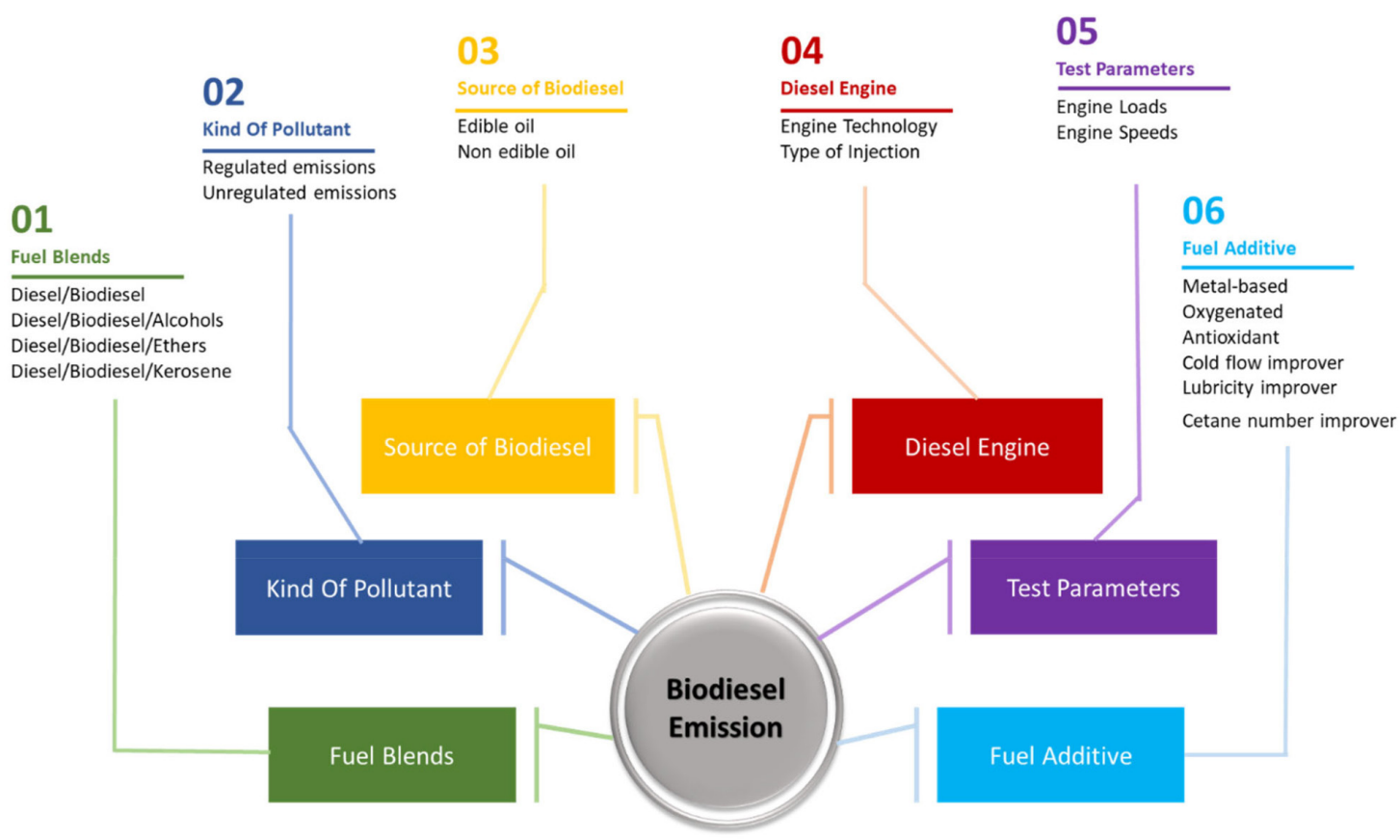

Figure 23. Main subjects related to emission studies with biodiesel, according to databases accessed in the last 15 years.

Several studies are available which evaluate the impacts on the pollutants emission profile from using ternary fuel mixtures. In a review published by Mofijur et al. ${ }^{470}$ the latest studies carried out to evaluate emissions of ternary mixtures with the addition of ethanol were summarized. The fuel blends evaluated had ethanol concentrations added to biodiesel/diesel blends ranging from 2 to $40 \% .{ }^{475} \mathrm{In}$ general, the addition of ethanol in biodiesel/diesel blends does not cause a clear increasing nor decreasing trend for $\mathrm{CO}, \mathrm{NO}_{\mathrm{x}}$ and $\mathrm{HC}$ emissions (regulated compounds). The emissions depended directly on the test conditions and technologies used..$^{470}$ Meanwhile, there are other studies which state the ethanol addition to diesel/biodiesel/ ethanol ternary mixtures could increase $\mathrm{CO}$ and $\mathrm{HC}$ emissions although they bring contributions by reducing $\mathrm{NO}_{\mathrm{x}}$ emissions, particulate matter and particle number concentrations. ${ }^{471-473}$

Although the vast majority of studies regarding vehicle emissions focused their analysis on regulated pollutants $\left(\mathrm{NO}_{\mathrm{x}}, \mathrm{CO}, \mathrm{PM}\right.$, and $\left.\mathrm{HC}\right)$ attention has been given to a large number of non-regulated compounds, which have potential carcinogenic and mutagenic effects. Among them, volatile (VOC) and semivolatile organic compounds (SVOC), such as PAHs, nitro-PAHs, quinones, carbonyl compounds (CC) and others ${ }^{476-484}$ can be highlighted. The addition of biodiesel in diesel can bring some benefits in reducing the emissions of those compounds. It should be noted, however, that different results can be observed, depending on the applied conditions. For instance, when $10 \% n$-butanol was added to biodiesel, the PAH emissions have decreased, while addition of a larger amount of $n$-butanol has led to the opposite result. Thus, the PAH production is driven not only by the combustion process but also by the fuel origin. ${ }^{485}$ Table 11 shows the main studies about the effect of the use of biodiesel on emissions of both regulated and unregulated pollutants. The complete table, including observed results and details from the use of biodiesel and other fuels, is found in the Supplementary Information section.

In terms of pollutant emissions, the increase of biodiesel added to diesel must be carefully evaluated. In general, there are pollutants emitted in lower concentrations when biodiesel is added (such as HPAs, $\mathrm{CO}$ and $n$-alkanes), while other pollutants are emitted in a higher concentration (carbonyl compounds, major ions and $\mathrm{NO}_{\mathrm{x}}$ ) when compared to pure diesel. In this sense, it is of utmost importance to develop solutions able to mitigate negative impacts caused by emissions from high biodiesel content blends. The use of combustionenhancing additives could be a viable alternative. In addition, there is a significant number of studies which highlights some carcinogenic compounds emitted during the incomplete combustion process. Those carcinogenic compounds could be regulated by law in a near future, imposing emission limits. The increase in the biodiesel content should consider these contributions.

\section{Trends in Biodiesel Patents}

In January 2021, a technological prospecting mapping on biodiesel was carried out on the Derwent World Patents 
Table 11. Main studies recently published regarding pollutants exhausted through blended or unblended biodiesel fuel

\begin{tabular}{|c|c|c|c|c|}
\hline Sampling year & Pollutant & Phase & Fuel tested & Reference \\
\hline 2004 & PAH & particulate & B100 & 486 \\
\hline $2004 / 2005$ & PAH & particulate & $\begin{array}{l}\text { diesel fueled heavy-duty vehicles, diesel } \\
\text { burning from ships and smaller boats and dust } \\
\text { resuspension through circulation of buses }\end{array}$ & 482 \\
\hline $2006 / 2007$ & PAH & particulate & diesel & 487 \\
\hline 2008 & PAH, major ions & particulate & B3 & 481 \\
\hline 2008 & $\mathrm{CC}$ & gaseous & $\begin{array}{c}\text { diesel, B2, B5, B10, B20, B50, B75 and } \\
\text { B100 from soybean biodiesel and residual oil } \\
\text { biodiesel }\end{array}$ & 488 \\
\hline 2008 & $\begin{array}{l}\text { formaldehyde, acetaldehyde, acrolein, acetone, } \\
\text { propionaldehyde, butyraldehyde, benzaldehyde }\end{array}$ & gaseous & $\begin{array}{c}\text { diesel, B2, B5, B10 and B20 from castor oil } \\
\text { biodiesel }\end{array}$ & 489 \\
\hline 2009 & $\mathrm{CC}, \mathrm{CO}, \mathrm{CO}_{2}, \mathrm{NO}_{\mathrm{x}}$ & gaseous & $\begin{array}{l}\text { B5 from soybean biodiesel, castor oil biodiesel } \\
\text { and residual oil biodiesel }\end{array}$ & 483 \\
\hline 2009 & $\mathrm{CC}$ & gaseous & diesel and B100 from soybean oil & 490 \\
\hline 2010 & 2-nitrobenzanthrone, 3-nitrobenzanthrone & particulate & B4 & 491 \\
\hline 2010 & PAH, nitro-PAH, quinones & particulate & B4 & 478 \\
\hline 2010 & quinones & particulate & B4 & 479 \\
\hline 2010 & $\begin{array}{c}\text { low-molecular weight carboxylate, water-soluble } \\
\text { inorganic ions }\end{array}$ & particulate & B5 & 492 \\
\hline 2010 & $\mathrm{CC}$ & gaseous & B5 & 484 \\
\hline 2011 & carbonyl, $\mathrm{PAH}$, nitro-PAH, oxy-PAH & particulate and gaseous & $\begin{array}{l}\text { B10, B20 and B30 from fresh and oxidized } \\
\text { biodiesel of different source materials }\end{array}$ & 493 \\
\hline 2013 & $\mathrm{CC}$ & particulate & B5 & 476 \\
\hline 2013 & $\begin{array}{c}\text { water-soluble transition metals, } \mathrm{PAH} \text {, nitro-PAH, } \\
\text { quinones }\end{array}$ & particulate & B7 & 477 \\
\hline 2014 & PAH & particulate & $\mathrm{B} 5, \mathrm{~B} 25, \mathrm{~B} 50$ and $\mathrm{B} 100$ & 480 \\
\hline 2014 & $\mathrm{NO}_{x}, \mathrm{CO}, \mathrm{HC}, \mathrm{CO}_{2}, \mathrm{PM}$ & particulate and gaseous & $\mathrm{B} 100, \mathrm{~B} 5$ and B5E6 & 475 \\
\hline 2014 & $\mathrm{NO}_{\mathrm{x}}, \mathrm{NH}_{3}, \mathrm{~N}_{2} \mathrm{O}$ & gaseous & $\begin{array}{c}\text { low-sulfur diesel, ultra low sulfur diesel and } \\
\text { B20 from soybean biodiesel }\end{array}$ & 494 \\
\hline 2014 & carbonyl & gaseous & $\begin{array}{l}\text { diesel, B50 and B100 from animal-fat biodiesel } \\
\text { and diesel containing 5\% of a tire pyrolysis } \\
\text { liquid }\end{array}$ & 495 \\
\hline 2015 & $\mathrm{PAH}$, nitro-PAHs, petroleum biomarkers & particulate & $\begin{array}{l}\text { ultra-low sulfur diesel, swedish low aromatic } \\
\text { diesel and neat soybean biodiesel }\end{array}$ & 496 \\
\hline 2015 & sulfur & gaseous & diesel with different sulfur contents & 497 \\
\hline 2016 & $\begin{array}{l}\mathrm{CO}, \mathrm{NO}_{\mathrm{x}} \text {, saturated hydrocarbon compounds, } \\
\text { unsaturated hydrocarbons, aldehydes, alcohols, } \\
\mathrm{SO}_{2} \text {, formic acid, benzene }\end{array}$ & gaseous & diesel, B5 and B20 from Karanja oil biodiesel & 498 \\
\hline 2017 & organic carbon, elemental carbon & particulate & $\begin{array}{l}\text { B4 from commercial soybean biodiesel. B50 } \\
\text { and B100 from waste cooking biodiesel }\end{array}$ & 499 \\
\hline 2017 & PAH, inorganic ions & particulate & B20 from waste cooking biodiesel & 500 \\
\hline 2017 & $\begin{array}{c}\text { CC, unsaturated hydrocarbons, aromatic } \\
\text { compounds }\end{array}$ & particulate and gaseous & $\begin{array}{l}\text { diesel, B20, B50, B75 and B100 from waste } \\
\text { cooking biodiesel }\end{array}$ & 501 \\
\hline 2018 & $\mathrm{PAH}$, nitro-PAHs & particulate & $\begin{array}{l}\text { B5 and B20 from ultra-low sulfur diesel and } \\
\text { soybean biodiesel }\end{array}$ & 502 \\
\hline 2019 & $\begin{array}{c}\mathrm{CO}, \mathrm{CO}_{2}, \mathrm{O}_{2} \text {, total hydrocarbon, } \mathrm{NO}_{\mathrm{x}} \text {, aldehyde, } \\
\text { alkene }\end{array}$ & gaseous & $\begin{array}{c}\text { ultra-low sulfur diesel, B20, B50, B75 and } \\
\text { B100 with different oxygen contents from } \\
\text { waste cooking biodiesel }\end{array}$ & 503 \\
\hline 2019 & $\begin{array}{c}\text { organic carbon, elemental carbon, } \mathrm{PAH}, \\
n \text {-alkanes, fatty acids, inorganic ions }\end{array}$ & particulate & $\mathrm{B} 5, \mathrm{~B} 10$ and $\mathrm{B} 20$ from waste cooking biodiesel & 504 \\
\hline 2019 & $\mathrm{PAH}$, carbonyls & particulate and gaseous & $\begin{array}{l}\text { B80 from palm oil biodiesel, animal fat } \\
\text { biodiesel and soybean biodiesel }\end{array}$ & 505 \\
\hline 2019 & persistent organic pollutants, $\mathrm{PAH}$ & particulate & $\begin{array}{l}\text { diesel, B20, B40, B60, B80 and B100 from } \\
\text { waste cooking biodiesel }\end{array}$ & 506 \\
\hline 2020 & PAH & particulate & $\begin{array}{l}\text { diesel with no oxygen content and a glycerine } \\
\text { fuel containing } 80 \% \text { of diesel and } 20 \% \text { of a } \\
\text { blend containing waste cooking biodiesel, fatty } \\
\text { acid glycerol formal ester and acetals }\end{array}$ & 507 \\
\hline
\end{tabular}




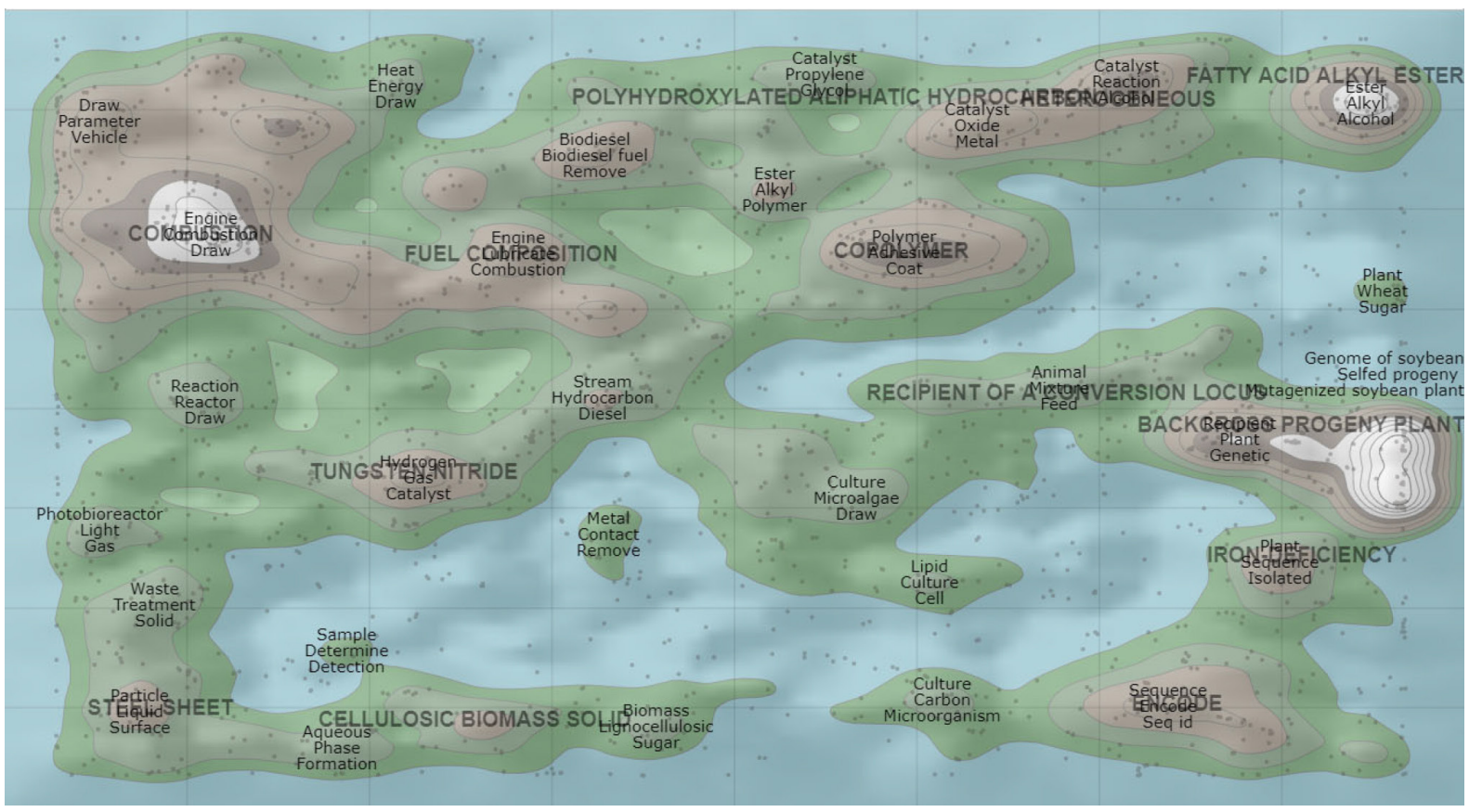

Figure 24. Technological trend map of patents filed on biodiesel. Source: Derwent World Patents Index platform (January, 2021).

Index platform. ${ }^{508} \mathrm{An}$ increasing number of patent deposits were observed over the last 10 years, currently existing more than 7,000 active patents. The companies that have filed the most patents in recent years on biodiesel were BASF (1942), Xyleco (1826), Monsanto Technology LLC (1074) and Ford Global Tech LLC (1052). The inventors who most published patents on biodiesel were Medoff, Marshall (1513); Eby, William H. (837); Masterman, Thomas Craig (746) and Masterman, Thomas (626). Figure 24 presents a technological trend map of the patents filed on biodiesel. There are three major areas of interest related to the topic: (i) combustion process, (ii) production plants, and (iii) biodiesel production process. In addition, it is interesting to note new areas regarding biodiesel which are emerging recently (highlighted in green in Figure 24). Among the new applications, it is interesting to highlight the insertion of biodiesel in the production line of mineral diesel (stream hydrocarbon diesel), with biomass coprocessing in refining processes where two or more biofuels are incorporated into the mineral fuel. This opens up great development opportunities, in which methodologies for determining renewable content in mineral fuels become an important demand with a view to producing intellectual property.

\section{Conclusions}

Biodiesel/diesel blends are available at gas stations over the world. Particularly in Brazil, there is legal provision for the market to provide the B15 until 2023, and expected to reach B20 in 2028. The use of this biofuel has been consolidated over the years, as a result of intense collaboration between the productive and academic sectors. The number of scientific publications on biodiesel per year is quite significant and covers all the subjects associated with its use, from the raw material to the vehicle emission profile.

In the last 15 years, several feedstocks have been evaluated in relation to oil productivity and physicochemical characteristics. The growing number of studies aiming at evaluating microalgae biomass is worth mentioning. The knowledge that has been accumulated on this type of raw material connected with advances in genetic engineering can make its use feasible and make it a raw material with great potential for the production of biodiesel.

The main process of biodiesel production from the transesterification of oils and fats still uses homogeneous basic catalysis. The fast rates, together with the catalysts affordable prices, are responsible for the success of this process, in spite of the fact these catalysts cannot be recovered, the need of laborious purification steps and waste generation. The forefront scenario indicates heterogeneous catalysis will emerge as the future of biodiesel processes. The main benefits are the possibility of catalyst reutilization or use in continuous flow mode, the reduction of purification steps and generation of less waste. Heterogeneous basic catalysts still present some drawbacks, like leaching of the active phase or the necessity of energy demanding regeneration. Heterogeneous acid catalysts 
require more severe reaction conditions and they also can suffer deactivation. Therefore, more research is needed to overcome these problems, before a commercial process of biodiesel production using heterogeneous catalysts can be implemented. Enzymes are active and selective for biodiesel production. However, the slow reaction rates, together with the associated highly costs, enzymatic catalysis is still far from being commercially used in biodiesel production processes. In parallel with efforts to make the use of heterogeneous catalysis feasible, studies involving the use of intensification technologies have been advancing on laboratory and industrial scales.

Regarding additives for biodiesel, there are still few studies of corrosion inhibitors evaluated under conditions of biodiesel storage. Research on innovative products with biocidal action for biodiesel/diesel blends also deserve more attention. In Brazil, the use of this type of additive needs to be regulated. The search for multifunctional products is certainly the biggest challenge for biodiesel quality assurance and preservation of vehicular metallic materials, transport and storage systems of this biofuel.

Finally, the publications on the effect of biodiesel/diesel blends in emissions of pollutants have been collecting an important set of results on the impact of increasing the biodiesel content in the emission profile. These studies indicated, in terms of pollutants emission, the increment of biodiesel content in diesel should be carefully evaluated since some pollutants (e.g., carbonyl compounds, major ions and $\mathrm{NO}_{\mathrm{x}}$ ) are emitted in higher concentrations in those conditions.

\section{Challenges and Perspectives}

The use of biodiesel has been consolidated in the energy matrix of several countries, at the same time some of them are announcing their plans to ban fossilfuel based vehicles in the following years. ${ }^{509}$ Despite the enormous volume of studies carried out in the last 15 years and the advances achieved, there still are many challenges in this field, which require more investments in research and innovation. We highlight some relevant topics: $(i)$ intensification of genetic researches in oil plants to improve the productivity and yield of oil for biodiesel; (ii) development of sustainable, technically viable and cost-competitive microalgae production technologies; (iii) development of viable heterogeneous catalysts and implementation of a continuous process; (iv) optimization of intensification technologies (such as microwave heating, ultrasonic irradiation, among others) for biodiesel production; $(v)$ development of multifunctional additives in order to guarantee the quality of both pure biodiesel and biodiesel/diesel blends under storage conditions; ( $v i$ ) establishment of new uses for glycerin; (vii) evaluation of the impacts on the pollutants emission profile derived from the increasing the biodiesel content in mineral diesel, which could, in turn, contribute to guide decisions in possibly expanding the use of this biofuel; and (viii) development of combustion improver additives as an strategy to mitigate the worsening of some pollutants emission profile when high biodiesel content blends are combusted.

\section{Supplementary Information}

Supplementary information associated with this article can be found available free of charge at http://jbcs.sbq.org. br as PDF file.

\section{Acknowledgments}

The authors would like to thank the Agência Nacional de Desenvolvimento Científico e Tecnológico (CNPq), Serviço Nacional de Treinamento Industrial, Departamento Regional da Bahia (SENAI/CIMATEC) the National Institute of Science and Technology (INCT) for Energy \& Environment (INCT E\&A, project CNPq No. 465497/2014-4), Project 'Pesquisando Kirimurê: Convergindo Educação, Ciência, Tecnologia e Inovação' (CNPq No. 442187/2018-1) and the Interdisciplinary Center for Energy and Environment (CIEnAm) from Universidade Federal da Bahia. We are also thankful for funding from CAPES (finance code 001). In addition, funding from Fundação de Apoio à Pesquisa do Estado do Rio de Janeiro (FAPERJ) and from Fundação de Apoio à Pesquisa do Estado da Bahia (FAPESB) are also acknowledged.

\section{Author Contributions}

Michelle J. C. Rezende was responsible for conceptualization, formal analysis, investigation, visualization, writing original draft, writing review and editing; Ana Lúcia de Lima, Bárbara V. Silva, Claudio J. A. Mota, Ednildo A. Torres, Gisele O. da Rocha, Ingrid M. M. Cardozo, Kênia P. Costa, Pedro A. P. Pereira for formal analysis, investigation, visualization, writing original draft and writing review; Lilian L. N. Guarieiro and Sabrina Martinez for conceptualization, formal analysis, investigation, visualization, writing original draft and writing review; Jailson B. de Andrade for conceptualization, formal analysis, investigation, visualization, writing original draft, writing review and supervision. 


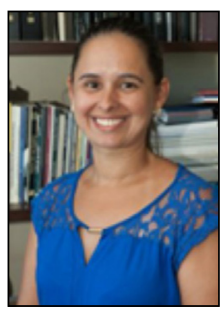

Michelle J. C. Rezende is an associate professor at Federal University of Rio de Janeiro (UFRJ), Brazil. She is graduated in Chemistry (2002) and doctorate in Chemistry (2006) from the same university. She is a permanent professor in the Chemistry Graduate Program (PGQu) and in the Chemistry Professional Master's Program in the National Network (PROFQUI), both at Institute of Chemistry, UFRJ. Currently, she is vice-coordinator of PROFQUI. Her area of expertise is organic chemistry and her present research has focused mainly on the development of additives for biodiesel and for use in oil production.

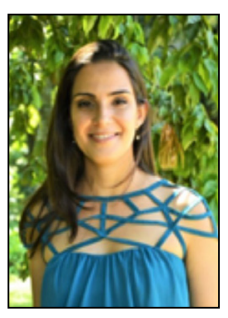

Ana Lúcia de Lima received her Bachelor's degree (2011) with Technological Assignments in Chemical Sciences from the Federal University of Uberlândia (UFU), Brazil. She received her MSc degree (2013) and PhD (2017) in Chemistry from the Federal University of Rio de Janeiro (UFRJ), Brazil. Her research work is focused on catalysis, biofuel and synthesis of hybrid materials. She was a post-doctoral (2018) from the same institution, with research focused on the development of hydrogels for advanced oil recovery (EOR). Currently, she is a lecturer at the Department of Analytical Chemistry at UFRJ. Her present research is focused on the synthesis of hybrid materials for $\mathrm{CO}_{2}$ capture, transformation of biomass and heterogeneous catalysis.

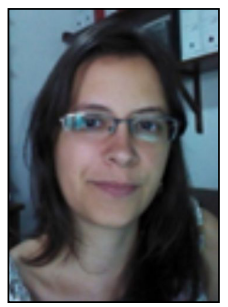

Bárbara V. Silva was born in Rio de Janeiro, Brazil. She graduated cum laude from the UFRJ with a Bachelor's degree in Chemistry in 2007. She earned her PhD in Chemistry from the UFRJ in 2010. At present, she is an Associate Professor at the UFRJ and National Coordinator of the Professional Master's Program in Chemistry on the National Network (PROFQUI). She is part of the editorial board of the Revista Virtual de Quimica $(R V q)$. Her research is focused on the synthesis of compounds with potential biologic activity and anticorrosion action. In addition, she has been working in chemistry teaching, acting in advisoring Master's thesis aimed at high school chemistry teachers.

Claudio J.A. Mota is graduated in Chemical Engineering at the Federal University of Rio de Janeiro, where he also obtained his doctoral degree in Chemistry and is presently

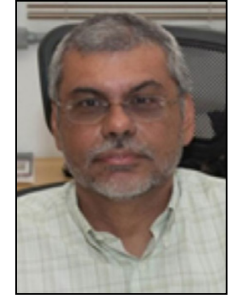

full professor as well as director of the Institute of Chemistry. He received the Technology Award from ABIQUIM and the Innovation Award from $S B Q$ for his work on glycerol transformation. He participates in the Brazilian Biodiesel Technology Network of the Ministry of Science and Technology. His research interests are focused on catalytic processes of biomass transformation and $\mathrm{CO}_{2}$ capture and conversion, with emphasis on the molecular aspects and innovative solutions.

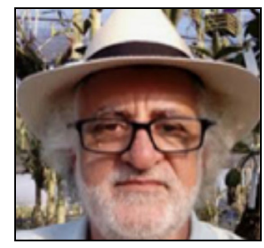

Ednildo A. Torres is coordinator of the Energy and Gas Laboratory at the Polytechnic School of UFBA. He has a post-doctorate at FAMU/ FSU US, a doctorate in Energy from UNICAMP, a Master's degree from the University of São Paulo, a graduate from the Federal University of Bahia. He has more than 35 years of experience in technological development between Industrial Research Centers and Universities. He is a full member of the Academy of Sciences of Bahia, was deputy coordinator of INCT Energia e Ambiente, headquartered at UFBA. He was Coordinator of the Technological Development and Entrepreneurship area at UFBA and CEO of the Institute of Energy and Environment of the Bahia State.

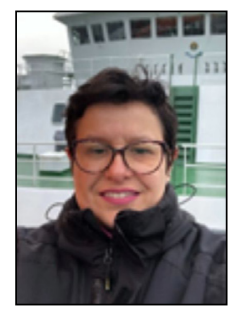

Gisele O. da Rocha has a Chemistry degree from Universidade Estadual de Maringá (UEM, 1998), a PhD in Chemistry from Universidade Estadual Paulista (UNESP, 2003), with a supervised internship at the Division of Environmental Health and Risk Management, School of Geography, The University of Birmingham, Birmingham, United Kingdom (2002). She did a 3-years post-doc at the Universidade Federal da Bahia (UFBA, 2006). Also, she took a 1-year sabbatical at the Department of Atmospheric and Oceanic Sciences at the University of California, Los Angeles (UCLA, 2016), Los Angeles, USA. She is an Associate Professor at Institute of Chemistry from UFBA since 2006.

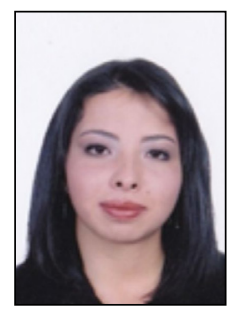

Ingrid M. M. Cardozo graduated in Food Chemistry at the Universidad Pedagógica Y Tecnológica De Colombia (UPTC) in 2013. She did an undergraduate internship in the research and development laboratory in chemistry at the Federal University 
of Bahia (UFBA) in 2011. She did a Master's in Analytical Chemistry at the UFBA (2017). She is currently a doctoral student in the Graduate Program in Science, Energy and Environment, at the Interdisciplinary Center for Energy and Environment at the UFBA. Her research involves analytical and environmental chemistry, whose main objectives are: the analysis of various chemical species in different phases, in addition to studying environmental matrices.

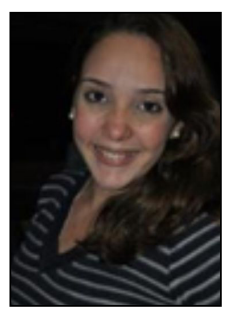

Kênia P. Costa holds a DSc in Chemistry (2018) and a MSc in Chemistry (2013) from the Graduate Program in Chemistry at the Institute of Chemistry at the Federal University of Rio de Janeiro, undergraduate degree in Chemistry and Bachelor in Chemistry from the University of Brasilia (2011). She has experience in the area of chemistry, with an emphasis on biofuels, natural products, high performance liquid chromatography and chemical transformations of organic compounds. Acting on the following topics: production of biodiesel, physicalchemical parameters of biodiesel, zeolites and adsorption of polyaromatic hydrocarbons, development of additives for biodiesel, chemical transformation of industrial waste, isolation of natural products, phytochemistry and bioguided studies. She has experience in teaching at the fundamental level to the superior level.

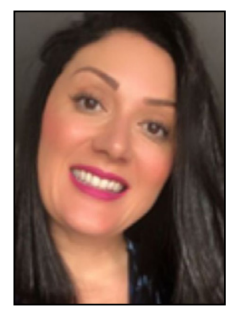

Lilian L. N. Guarieiro has graduated in Chemistry at Centro Universitário de Lavras (2003), Master in Organic Chemistry and Specialization in Petroleum Chemistry at Federal University of Rio de Janeiro (2006), PhD in Analytical Chemistry at Federal University of Bahia (2010), Sandwich Doctorate at Virgina Polytechnic Institute in Blacksburg, VA-USA and Pos-Doc by the National Institute of Science and Technology for Energy and Environment (2011). She is currently Coordinator of the Professional Master in Sustainable Development at SENAI CIMATEC. She has experience in Environmental Chemistry, Analytical Chemistry and Organic Chemistry with an emphasis on oil, gas and biofuel.

Pedro A. P. Pereira has graduate degree in Chemistry (UnB, 1977), Specialization in Nuclear Technology (UFMG, 1980), MSc degree in Chemistry (PUC-RJ, 1986), DSc degree in Chemistry (UFBA, 1997) and posdoc at UCLA (2000). He is, since 2019, a retired Full Professor at UFBA and takes part as Professor of the MSc

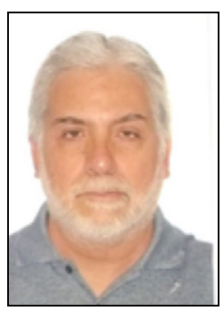

Program in Sustainable Development from the Centro Universitário SENAICIMATEC. He was holder of a level 2 Research Grant from $\mathrm{CNPq}$ until 2020 and has been a member of the Brazilian Academy of Sciences since 2011, as one of its founders. His experience is in Analytical and Environmental Chemistry, mainly on the following subjects: VOC, PAH, carbonyl compounds, atmospheric particulate matter, nanoaerosols, pesticides and food.

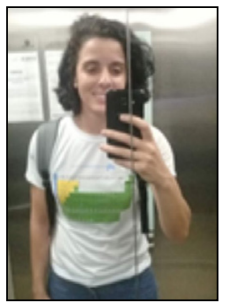

Sabrina Martinez has a Pharmacist degree from Catholic University of Pelotas (2006), master (2009) and PhD (2013) in chemistry from the Institute of Chemistry at the Federal University of Rio de Janeiro. She did sandwich doctorate at Karl-Franzens-Universität Graz - Austria. She is Visiting Professor at the Federal University of Bahia and acts in the Postgraduate Program in Energy and Environment (PGEnAm-UFBA) and in the Postgraduate Program of Marine Biotechnology (IEAPM/ UFF). Her research focus is synthesis, semisynthesis, isolation, determination and quantification of organic compounds from terrestrial and marine organisms.

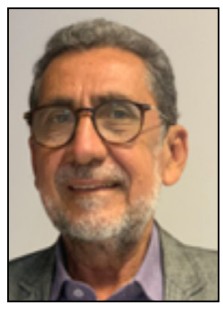

Jailson B. de Andrade is Full Professor and Deputy Provost for Research and Graduate Studies at the SENAI-CIMATEC. He is Member of the Brazilian Academy of Sciences (Regional VP), Bahia Academy of Science (President) and Fellow of the Royal Society of Chemistry. He was honored as Knight of the National Order of Scientific Merit, by the President of the Republic of Brazil (Commendateur in 1998 and Grã-Cruz in 2009) and received the most important condecoration of the Brazilian Chemical Society, the Simão Mathias Medal, in 2007. He is the Chair of the National Institute for Science and Technology in Energy and Environment since 2008 and Coordinator of the Interdisciplinary Center in Energy and Environment (UFBA).

\section{References}

1. Ma, F.; Hanna, M. A.; Bioresour. Technol. 1999, 70, 1.

2. Mata, T. M.; Martins, A. A.; Caetano, N. S.; Renewable Sustainable Energy Rev. 2010, 14, 217.

3. Meher, L. C.; Sagar, D. V.; Naik, S. N.; Renewable Sustainable Energy Rev. 2006, 10, 248. 
4. Leung, D. Y. C.; Wu, X.; Leung, M. K. H.; Appl. Energy 2010 , 87, 1083.

5. Chen, C.-Y.; Yeh, K.-L.; Aisyah, R.; Lee, D.-J.; Chang, J.-S.; Bioresour. Technol. 2011, 102, 71.

6. Hoekman, S. K.; Broch, A.; Robbins, C.; Ceniceros, E.; Natarajan, M.; Renewable Sustainable Energy Rev. 2012, 16, 143.

7. Atabani, A. E.; Silitonga, A. S.; Badruddin, I. A.; Mahlia, T. M. I.; Masjuki, H. H.; Mekhilef, S.; Renewable Sustainable Energy Rev. 2012, 16, 2070.

8. Kulkarni, M. G.; Dalai, A. K.; Ind. Eng. Chem. Res. 2006, 45, 2901.

9. Singh, S. P.; Singh, D.; Renewable Sustainable Energy Rev. 2010, 14, 200

10. Sharma, Y. C.; Singh, B.; Upadhyay, S. N.; Fuel 2008, 87, 2355.

11. Williams, P. J. B.; Laurens, L. M. L.; Energy Environ. Sci. 2010, 3,554 .

12. Lam, M. K.; Lee, K. T.; Mohamed, A. R.; Biotechnol. Adv. 2010, 28, 500 .

13. Halim, R.; Danquah, M. K.; Webley, P. A.; Biotechnol. Adv. 2012, 30, 709.

14. Ahmad, A. L.; Yasin, N. H. M.; Derek, C. J. C.; Lim, J. K.; Renewable Sustainable Energy Rev. 2011, 15, 584.

15. Pinto, A. C.; Guarieiro, L. L. N.; Rezende, M. J. C.; Ribeiro, N. M.; Torres, E. A.; Lopes, W. A.; Pereira, P. A. P.; de Andrade, J. B.; J. Braz. Chem. Soc. 2005, 16, 1313.

16. Zabeti, M.; Daud, W. M. A. W.; Aroua, M. K.; Fuel Process. Technol. 2009, 90, 770 .

17. Basha, S. A.; Gopal, K. R.; Jebaraj, S.; Renewable Sustainable Energy Rev. 2009, 13, 1628.

18. Fjerbaek, L.; Christensen, K. V.; Norddahl, B.; Biotechnol. Bioeng. 2009, 102, 1298.

19. Ranganathan, S. V.; Narasimhan, S. L.; Muthukumar, K.; Bioresour. Technol. 2008, 99, 3975.

20. Tan, T.; Lu, J.; Nie, K.; Deng, L.; Wang, F.; Biotechnol. Adv. 2010, 28, 628.

21. Monteiro, M. R.; Ambrozin, A. R. P.; Lião, L. M.; Ferreira, A. G.; Talanta 2008, 77, 593.

22. Jain, S.; Sharma, M. P.; Renewable Sustainable Energy Rev. 2010, 14, 667 .

23. Talebian-Kiakalaieh, A.; Amin, N. A. S.; Mazaheri, H.; Appl. Energy 2013, 104, 683.

24. Helwani, Z.; Othman, M. R.; Aziz, N.; Fernando, W. J. N.; Kim, J.; Fuel Process. Technol. 2009, 90, 1502.

25. Pullen, J.; Saeed, K.; Renewable Sustainable Energy Rev. 2012, 16,5924

26. Menezes, R. S.; Biodiesel no Brasil: Impulso Tecnológico, vol. 1, $1^{\text {st }}$ ed.; Artecor Gráfica e Editora Ltda: Lavras, BR, 2016.

27. https://www.politize.com.br/eco-92/, accessed in March 2021.

28. Ministério da Ciência e Tecnologia; Portaria MCT No. 702, de 30 de outubro de 2002, available at https://www.camara.leg.br/
proposicoesWeb/prop_mostrarintegra;jsessionid=8362AE01 F515A95B019F0C252F60C72C.proposicoesWebExterno2?c odteor $=122459 \&$ filename=LegislacaoCitada+-PL+526/2003, accessed in March 2021.

29. Pousa, G. P. A. G.; Santos, A. L. F.; Suarez, P. A. Z.; Energy Policy 2007, 35, 5393.

30. https://www.gov.br/agricultura/pt-br/assuntos/agriculturafamiliar/biodiesel/arquivos/cartilha-do-programa-nacionalde-producao-e-uso-de-biodiesel-pnpb.pdf, accessed in March 2021.

31. Presidência da República Casa Civil; Lei No. 11.097, de 13 de janeiro de 2005, Dispõe sobre a Introdução do Biodiesel na Matriz Energética Brasileira; Diário Oficial da União (DOU), Brasília, Brazil, 2005, available at https://www.planalto.gov. br/ccivil_03/_ato2004-2006/2005/lei/111097.htm, accessed in March 2021.

32. Suarez, P. A. Z.; Meneghetti, S. M. P.; Quim. Nova 2007, 30, 2068.

33. http://www.anp.gov.br/biocombustiveis/biodiesel, accessed in February 2021.

34. http://g20.org.tr/about-g20/g20-members/, accessed in February 2021.

35. https://sta.uwi.edu/iir/normangirvanlibrary/sites/default/ files/normangirvanlibrary/documents/The $\% 20$ OECD $\% 20$ in $\% 20$ the $\% 20$ G20\%20A\%20Natural\%20Partner\%20In\%20 Global\%20Governance.pdf, accessed in February 2021.

36. https://www.biofuelsdigest.com/bdigest/2018/07/30/germanbiodiesel-and-ethanol-blending-both-jump-in-may/, accessed in February 2021.

37. https://www.ifeu.de/landwirtschaft/pdf/premia-biodieselgermany.pdf, accessed in February 2021.

38. https://www.etipbioenergy.eu/databases/reports/376-overviewof-biofuel-policies-and-markets-across-the-eu-28, accessed in April 2021.

39. https://www.spglobal.com/platts/en/market-insights/latestnews/agriculture/072618-analysis-german-jan-may-biodieselsales-rise-129-on-year-ethanol-sales-up-76, accessed in February 2021.

40. https://www.biofuelsdigest.com/bdigest/2013/07/15/germanbiodiesel-feedstocks-are-diversifying/, accessed in February 2021.

41. ht tps://ww w. legifrance.gouv.fr/jorf/id/ JORFTEXT000024562958/, accessed in March 2021.

42. https://gain.fas.usda.gov/Recent\%20GAIN\%20Publications/ Biofuels\%20Annual_The\%20Hague_EU-28_6-19-2017.pdf, accessed in February 2021.

43. https://www.russiangost.com/p-71805-gost-r-52368-2005.aspx, accessed in March 2021.

44. https://mpra.ub.uni-muenchen.de/76729/1/MPRA_ paper_76729.pdf, accessed in February 2021.

45. https://www.biofuelsdigest.com/bdigest/2017/09/19/uk-sets- 
out-policy-to-raise-biofuels-blends-through-2032/, accessed in February 2021.

46. https://eneken.ieej.or.jp/data/6380.pdf, accessed in February 2021.

47. Masiero, G.; Rev. Bras. Polit. Int. 2011, 54, 97.

48. https://apps.fas.usda.gov/newgainapi/api/Report/DownloadRep ortByFileName?fileName=Oilseeds $\% 20$ and $\% 20$ Products $\% 20$ Annual_Seoul_Korea\%20-\%20Republic\%20of_3-5-2019, accessed in March 2021.

49. Pradhan, A.; Mbohwa, C.; Renewable Sustainable Energy Rev. 2014, 39, 1089.

50. https://www.tralac.org/discussions/article/10962-prospects-fora-regional-biofuels-industry-in-southern-africa.html, accessed in February 2021.

51. http://www.miningweekly.com/article/biodiesel-not-anaffordable-solution-for-s-african-mines-2018-02-07, accessed in February 2021.

52. https://gain.fas.usda.gov/Recent\%20GAIN\%20Publications/ Biofuels\%20Annual_Buenos\%20Aires_Argentina_7-17-2017. pdf, accessed in February 2021.

53. https://www.spglobal.com/platts/en/market-insights/latestnews/agriculture/020520-argentina-data-biodiesel-output-fellin-november-on-year-on-lower-exports, accessed in February 2021.

54. https://www.biodieselbr.com/noticias/inter/argentina/ industria-de-biodiesel-na-argentina-sofre-com-paralisia-nasexportacoes-300519, accessed in February 2021.

55. https://gain.fas.usda.gov/Recent $\% 20$ GAIN\%20Publications/ Biofuels\%20Annual_Buenos\%20Aires_Argentina_7-21-2016. pdf, accessed in February 2021.

56. http://www.biodieselmagazine.com/articles/2516872/2020biodiesel-plant-map-reflections, accessed in February 2021.

57. https://gain.fas.usda.gov/Recent\%20GAIN\%20Publications/ Biofuels\%20Annual_Ottawa_Canada_4-6-2018.pdf, accessed in February 2021.

58. https://www.afdc.energy.gov/fuels/biodiesel_blends.html, accessed in February 2021.

59. https://afdc.energy.gov/files/pdfs/2527.pdf, accessed in March 2021.

60. https://www.eia.gov/biofuels/biodiesel/production/, accessed in February 2021.

61. http://task39.sites.olt.ubc.ca/files/2013/05/The-Potential-ofbiofuels-in-China-IEA-Bioenergy-Task-39-September-2016. pdf, accessed in February 2021.

62. https://gain.fas.usda.gov/Recent\%20GAIN\%20Publications/ Biofuels\%20Annual_Tokyo_Japan_8-15-2017.pdf, accessed in February 2021.

63. https://gain.fas.usda.gov/Recent\%20GAIN\%20Publications/ Biofuels\%20Annual_New\%20Delhi_India_6-27-2017.pdf, accessed in February 2021.

64. https://www.deccanherald.com/business/business-news/union- budget-2020-what-the-biofuels-industry-expects-798643.html, accessed in February 2021.

65. https://gain.fas.usda.gov/Recent\%20GAIN\%20Publications/ Biofuels\%20Annual_Jakarta_Indonesia_6-20-2017.pdf, accessed in February 2021.

66. https://www.reuters.com/article/idUSKCN1IP18L, accessed in April 2021.

67. https://www.reuters.com/article/indonesia-biodiesel/indonesiabiodiesel-group-says-more-capacity-in-2020-could-helpexports-idUSL4N2A32V4, accessed in February 2021.

68. https://www.reuters.com/article/us-indonesia-biodiesel/ indonesia-bets-big-on-biodiesel-to-limit-costs-of-oil-importsidUSKBN1KS0CC, accessed in February 2021.

69. Rehan, M.; Gardy, J.; Demirbas, A.; Rashid, U.; Budzianowski, W. M.; Pant, D.; Nizami, A. S.; Bioresour. Technol. 2018, 250, 17.

70. Bölük, G.; Koç, A. A.; Int. J. Energy Econ. Policy 2013, 3, 14; https://gain.fas.usda.gov/Recent\%20GAIN\%20Publications/ Biofuels\%20Annual_Ankara_Turkey_8-13-2010.pdf, accessed in February 2021.

71. Coronado, M. A.; Montero, G.; García, C.; Valdez, B.; Ayala, R.; Pérez, A.; Energies 2017, 10, 631.

72. http://www.cedrssa.gob.mx/files/b/13/56Producci\%C3\%B3n\% 20y\%20comercio\%20de\%20biocombustibles.pdf, accessed in April 2021.

73. http://www.diputados.gob.mx/LeyesBiblio/pdf/LPDB.pdf, accessed in February 2021.

74. http://www.biofuelsdigest.com/bdigest/2017/05/22/mexicanbiodiesel-producer-growing-thanks-to-higher-fossil-prices-butmargins-thin/, accessed in February 2021.

75. https://gain.fas.usda.gov/Recent\%20GAIN\%20Publications/ Biofuels\%20Annual_Canberra_Australia_8-15-2017.pdf, accessed in February 2021.

76. Miglietta, P. P.; Giove, S.; Toma, P.; Ecol. Indic. 2018, 85, 1231.

77. Zentou, H.; Rosli, N. S.; Wen, C. H.; Abdul Azeez, K.; Gomes, C.; Iran. J. Chem. Chem. Eng. 2019, 38, 173.

78. https://www.ufop.de/files/7215/7953/0161/WEB_UFOP_ Global_Supply_Report_A5_EN_19_20.pdf, accessed in February 2021.

79. http://www.anp.gov.br/publicacoes/anuario-estatistico/5809anuario-estatistico-2020, accessed in February 2021.

80. http://www.anp.gov.br/producao-de-biocombustiveis/biodiesel/ informacoes-de-mercado, accessed in February 2021.

81. César, A. S.; Werderits, D. E.; Saraiva, G. L. O.; Guabiroba, R. C. S.; Renewable Sustainable Energy Rev. 2017, 72, 246.

82. Deeba, F.; Patel, A.; Arora, N.; Pruthi, V.; Pruthi, P. A.; Negi, Y. S.; Environ. Sci. Pollut. Res. 2018, 25, 353.

83. Górnaś, P.; Ramos, M. J.; Montano, M. C.; Rudzińska, M.; Radziejewska-Kubzdela, E.; Grygier, A.; Eur. J. Lipid Sci. Technol. 2018, 120, 1700147.

84. Anwar, M.; Rasul, M. G.; Ashwath, N.; Nabi, M. D. N.; Energy Rep. 2019, 5, 280. 
85. Yesilyurt, M. K.; Cesur, C.; Aslan, V.; Yilbasi, Z.; Renewable Sustainable Energy Rev. 2020, 119, 109574.

86. Niju, S.; Balajii, M.; Anushya, C.; Int. J. Green Energy 2019 , 16,702 .

87. Arumugam, A.; Ponnusami, V.; Renewable Energy 2019, 131, 459.

88. Yesilyurt, M. K.; Cesur, C.; Fuel 2020, 265, 117025.

89. Abraham, J.; Kumar, R. S.; Xavier, F.; Mathew, D. M.; Int. J. Agric. Biosys. Eng. 2015, 9, 1190.

90. Chung, K. H.; Kim, J.; Lee, K. Y.; Biomass Bioenergy 2009, 33,155 .

91. Sivaramakrishnan, R.; Muthukumar, K.; Energy Fuels 2012, 26, 6387; Sivaramakrishnan, R.; Muthukumar, K.; J. Biosci. Bioeng. 2014, 117, 86; Jalilian, N.; Najafpour, G. D.; Khajouei, M.; ChemBioEng Rev. 2020, 7, 18.

92. Kim, K. H.; Lee, O. K.; Kim, C. H.; Seo, J.-W.; Oh, B.-R.; Lee, E. Y.; Bioresour. Technol. 2016, 211, 472.

93. Patel, A.; Matsakas, L.; Rova, U.; Christakopoulos, P.; Biotechnol. Biofuels 2018, 11, 169.

94. Ashokkumar, V.; Agila, E.; Sivakumar, P.; Salam, Z.; Rengasamy, R.; Ani, F. N.; Energy Convers. Manage. 2014, $88,936$.

95. Sivaramakrishnan, R.; Incharoensakdi, A.; Fuel 2017, 191, 363.

96. Al-lwayzy, S. H.; Yusaf, T.; Renewable Energy 2017, 101, 690; Chen, Y. H.; Huang, B. Y.; Chiang, T. H.; Tang, T. C.; Fuel 2012, 94, 270; Cheng, Y.; Zhou, W.; Gao, C.; Lan, K.; Gao, Y.; Wu, Q.; J. Chem. Technol. Biotechnol. 2009, 84, 777.

97. Cao, H.; Zhang, Z.; Wu, X.; Miao, X.; BioMed Res. Int. 2013, 2013, 930686; Elystia, S.; Muria, S. R.; Erlangga, H. F.; Environ. Health Eng. Manage. J. 2020, 7, 1.

98. Ehimen, E. A.; Sun, Z. F.; Carrington, C. G.; Fuel 2010, 89, 677; Ehimen, E. A.; Sun, Z.; Carrington, G. C.; Procedia Environ. Sci. 2012, 15, 47.

99. Jo, Y. J.; Lee, O. K.; Lee, E. Y.; Bioresour. Technol. 2014, 158, 105.

100. Arroussi, H. E.; Benhima, R.; Mernissi, N. E.; Bouhfid, R.; Tilsaghani, C.; Bennis, I.; Wahby, I.; Renewable Energy 2017, 113,1515 .

101. Suganya, T.; Kasirajan, R.; Renganathan, S.; Bioresour. Technol. 2014, 156, 283.

102. Kings, A. J.; Raj, R. E.; Miriam, L. R. M.; Visvanathan, M. A.; Energy Convers. Manage. 2017, 141, 224.

103. Razon, L. F.; Tan, R. R.; Appl. Energy 2011, 88, 3507.

104. Srinuanpan, S.; Cheirsilp, B.; Prasertsan, P.; Kato, Y.; Asano, Y.; Renewable Energy 2018, 122, 507.

105. Jazzar, S.; Olivares-Carrillo, P.; de los Ríos, A. P.; Marzouki, M. N.; Acién-Fernández, F. G.; Fernández-Sevilla, J. M.; MolinaGrima, E.; Smaali, I.; Quesada-Medina, J.; Appl. Energy 2015 , 148, 210.

106. Moazami, N.; Ashori, A.; Ranjbar, R.; Tangestani, M.; Eghtesadi, R.; Nejad, A. S.; Biomass Bioenergy 2012, 39,
449; Koberg, M.; Cohen, M.; Ben-Amotz, A.; Gedanken, A.; Bioresour. Technol. 2011, 102, 4265.

107. Zendejas, F. J.; Benke, P. I.; Lane, P. D.; Simmons, B. A.; Lane, T. W.; Biotechnol. Bioeng. 2012, 109, 1146.

108. Siqueira, S. F.; Francisco, É. C.; Queiroz, M. I.; de Menezes, C. R.; Zepka, L. Q.; Jacob-Lopes, E.; Braz. J. Chem. Eng. 2016, $33,427$.

109. Wu, H.; Miao, X.; Bioresour. Technol. 2014, 170, 421.

110. Sivaramakrishnan, R.; Incharoensakdi, A.; Environ. Sci. Pollut. Res. 2017, 24, 4950

111. Bi, Z.; He, B. B.; McDonald, A. G.; Energy Fuels 2015, 29, 5018.

112. Rahman, M. A.; Aziz, M. A.; Ruhul, A. M.; Rashid, M. M.; $J$. Mech. Eng. Sci. 2017, 31, 3025.

113. Rahman, M. A.; Aziz, M. A.; Al-khulaidi, R. A.; Sakib, N.; Islam, M.; J. Radiat. Res. Appl. Sci. 2017, 10, 140.

114. Martínez, N.; Callejas, N.; Morais, E. G.; Costa, J. A. V.; Jachmanián, I.; Vieitez, I.; Fuel 2017, 202, 512.

115. Wang, H.; Gao, L.; Chen, L.; Guo, F.; Liu, T.; Bioresour. Technol. 2013, 142, 39.

116. Hossain, J.; Mod. Mech. Eng. 2011, 1, 77.

117. Kaur, N.; Ali, A.; Energy Sources, Part A 2013, 35, 184.

118. Nguyen, T.; Do, L.; Sabatini, D. A.; Fuel 2010, 89, 2285.

119. Vallinayagam, R.; Vedharaj, S.; Yang, W. M.; Lee, P. S.; Chua, K. J. E.; Chou, S. K.; Appl. Energy 2014, 130, 466.

120. Schinas, P.; Karavalakis, G.; Davaris, C.; Anastopoulos, G.; Karonis, D.; Zannikos, F.; Stournas, S.; Lois, E.; Biomass Bioenergy 2009, 33, 44.

121. Atabania, A. E.; Silitonga, A. S.; Ong, H. C.; Mahlia, T. M. I.; Masjuki, H. H.; Badruddin, I. A.; Fayaz, H.; Renewable Sustainable Energy Rev. 2013, 18, 211.

122. Chen, Y. H.; Chiang, T. H.; Chen, J. H.; Biomass Bioenergy 2013, 52, 15 .

123. Tuntiwiwattanapun, N.; Tongcumpou, C.; Ind. Crops Prod. 2018, 117, 359.

124. Kamil, M.; Ramadan, K. M.; Olabi, A. G.; Al-Ali, E. I.; Ma, X.; Awad, O. I.; Renewable Energy 2020, 147, 1880.

125. Shah, S. N.; Iha, O. K.; Alves, F. C. S. C.; Sharma, B. K.; Erhan, S. Z.; Suarez, P. A. Z.; Bioenergy Res. 2013, 6, 841.

126. Yahyaee, R.; Ghobadian, B.; Najafi, G.; Renewable Sustainable Energy Rev. 2013, 17, 312.

127. Capodaglio, A. G.; Callegari, A. J.; Environ. Manage. 2018, 216, 176.

128. da Silva, M. J.; de Souza, S. N. M.; Chaves, L. I.; Baricatti, R. A.; Nogueira, C. E. C.; Renewable Sustainable Energy Rev. 2013, 17, 278.

129. Nguyen, H. C.; Nguyen, N. T.; Su, C.-H.; Wang, F.-M.; Tran, T. N.; Liao, Y.-T.; Liang, S.-H.; Curr. Org. Chem. 2019, 23, 1499

130. Wang, Q.; Sen, B.; Liu, X.; He, Y.; Xie, Y.; Wang, G.; Sci. Total Environ. 2018, 631-632, 994. 
131. Guerfali, M.; Ayadi, I.; Sassi, H.-E.; Belhassen, A.; Gargouri, A.; Belghith, H.; Ind. Crops Prod. 2020, 145, 112103.

132. Passarinho, P. C.; Oliveira, B.; Dias, C.; Teles, M.; Reis, A.; da Silva, T. L.; Waste Biomass Valorization 2020, 11, 2075.

133. Callegari, A.; Bolognesi, S.; Cecconet, D.; Capodaglio, A. G.; Crit. Rev. Environ. Sci. Technol. 2020, 50, 384.

134. Adeniyi, O. M.; Azimov, U.; Burluka, A.; Renewable Sustainable Energy Rev. 2018, 90, 316.

135. Schneider, R. C. S.; Lima, M. M.; Hoeltz, M.; Neves, F. F.; John, D. K.; de Azevedo, A.; Algal Res. 2018, 32, 280.

136. Duarte, J. H.; Costa, J. A. V.; Bioresour. Technol. 2018, 247, 1242.

137. Ferreira, S. P.; Holz, J. C. P.; Costa, J. A. V.; Int. Food Res. J. 2018, 25, 408.

138. Lima, Â. M. F.; Torres, E. A.; Kiperstok, A.; Santos, G. F. M.; Clean Technol. Environ. Policy 2017, 19, 1523.

139. Freitas, B. C. B.; Cassuriaga, A. P. A.; Morais, M. G.; Costa, J. A. V.; Bioresour. Technol. 2017, 238, 248.

140. Pinho, D. M. M.; Oliveira, R. S.; dos Santos, V. M. L.; Marques, W. F.; Pinto, A. C.; Rezende, M. J. C.; Suarez, P. A. Z.; J. Braz. Chem. Soc. 2017, 28, 2429.

141. Zukovski, L.; Fontana, R. C.; Pauletti, G.; Camassola, M.; Dillon, A. J. P.; Braz. J. Chem. Eng. 2017, 34, 709.

142. Brennan, L.; Owende, P.; Renewable Sustainable Energy Rev. 2010, 14, 557.

143. Leong, W. H.; Lim, J. W.; Lam, M. K.; Uemura, Y.; Ho, Y. C.; Renewable Sustainable Energy Rev. 2018, 91, 950.

144. Chowdhury, H.; Loganathan, B.; Curr. Opin. Green Sustainable Chem. 2019, 20, 39.

145. Vadivel, M.; Arvindnarayan, S.; Kumar, G.; Shobana, S.; Dharmaraja, J.; Nguyen, D. D.; Chang, S. W.; Prabhu, K. K. S.; Waste Biomass Valorization 2020, 11, 1671.

146. Ma, Y.; Gao, Z.; Wang, Q.; Liu, Y.; Bioresour. Technol. 2018, 263,631 .

147. Klein, B. C.; Bonomi, A.; Maciel Filho, R.; Renewable Sustainable Energy Rev. 2018, 82, 1376.

148. Anto, S.; Mukherjee, S. S.; Muthappa, R.; Mathimani, T.; Deviram, G.; Kumar, S. S.; Verma, T. N.; Pugazhendhi, A.; Chemosphere 2020, 242, 125079.

149. Farrokh, P.; Sheikhpour, M.; Kasaeian, A.; Asadi, H.; Bavandi, R.; Biotechnol. Prog. 2019, 35, 1.

150. Souza, S. P.; Seabra, J. E. A.; Nogueira, L. A. H.; Biofuels 2018, 9, 455.

151. Maximo, G. J.; Magalhães, A. M. S.; Gonçalves, M. M.; Esperança, E. S.; Costa, M. C.; Meirelles, A. J. A.; Coutinho, A. A. P.; Fuel 2018, 226, 87.

152. Tang, H.; Abunasser, N.; Garcia, M. E. D.; Chen, M.; Ng, K. Y. S.; Salley, S. O.; Appl. Energy 2011, 88, 3324.

153. Wen, L.; Wang, Y.; Lu, D.; Hu, S.; Han, H.; Fuel 2010, 89, 2267.

154. Vanhercke, T.; Wood, C. C.; Stymne, S.; Singh, S. P.; Green, A. G.; Plant Biotechnol. J. 2013, 11, 197.
155. Sánchez, A. S.; Almeida, M. B.; Torres, E. A.; Kalid, R. A.; Cohim, E.; Gasparatos, A.; Renewable Sustainable Energy Rev. 2018, 81, 2744.

156. Vieira, J. S. C.; Sousa, T. L.; Rosas, L. S.; Lima, A. L.; Ronconi, C. M.; Mota, C. J. A.; Quim Nova 2018, 41, 10.

157. Knothe, G.; Fuel Process. Technol. 2005, 86, 1059.

158. Hegde, K.; Chandra, N.; Sarma, S. J.; Brar, S. K.; Veeranki, V. D.; Mol. Biotechnol. 2015, 57, 606.

159. Majidian, P.; Tabatabaei, M.; Zeinolabedini, M.; Naghshbandi, M. P.; Chisti, Y.; Renewable Sustainable Energy Rev. 2018, 82, 3863.

160. Shahid, A.; Rehman, A.; Usman, M.; Ashraf, M. U. F.; Javed, M. R.; Khan, A. Z.; Gill, S. S.; Mehmood, M. A.; Biotechnol. Appl. Biochem. 2020, 67, 41.

161. Jiang, W.; Gu, P.; Zhang, F.; Curr. Opin. Biotechnol. 2018, 53, 26.

162. Sarria, S.; Kruyer, N. S.; Peralta-Yahya, P.; Nat. Biotechnol. 2017, 35, 1158.

163. Gajewski, J.; Pavlovic, R.; Fischer, M.; Boles, E.; Grininger, M.; Nat. Commun. 2017, 8, 14650.

164. Dewick, P. M.; Medicinal Natural Products: A Biosynthetic Approach, $3^{\text {rd }}$ ed.; John Wiley \& Sons, Ltd: Chichester, UK, 2009.

165. Marella, E. R.; Holkenbrink, C.; Siewers, V.; Borodina, I.; Curr. Opin. Biotechnol. 2018, 50, 39.

166. Clemente, T. E.; Cahoon, E. B.; Plant Physiol. 2009, 151, 1030.

167. Kumar, A.; Ogita, S.; Yau, Y.-Y.; Biofuels: Greenhouse Gas Mitigation and Global Warming; Springer: New Delhi, India, 2018.

168. Kinney, A. J.; Genet. Eng. 1997, 19, 149.

169. Heppard, E. P.; Kinney, A. J.; Stecca, K. L.; Miao, G. H.; Plant Physiol. 1996, 110, 311.

170. Buhr, T.; Sato, S.; Ebrahim, F.; Xing, A.; Zhou, Y.; Mathiesen, M.; Schweiger, B.; Kinney, A.; Staswick, P.; Clemente, T.; Plant J. 2002, 30, 155.

171. Graef, G.; laVallee, B. J.; Tenopir, P.; Tat, M.; Schweiger, B.; Kinney, A. J.; van Gerpen, J. H.; Clemente, T. E.; Plant Biotechnol. J. 2009, 7, 411.

172. Sheikh, R.; Choi, M.; Im, J.; Park, Y.; J. Ind. Eng. Chem. 2013, 19, 1413.

173. Gardy, J.; Rehan, M.; Hassanpour, A.; Lai, X.; Nizami, A.-S.; J. Environ. Manage. 2019, 249, 109316.

174. Aransiola, E. F.; Ojumu, T. V.; Oyekola, O. O.; Madzimbamuto, T. F.; Ikhu-Omoregbe, D. I. O.; Biomass Bioenergy 2014, 61, 276.

175. Chua, S. Y.; Periasamy, L. A. P.; Goh, C. M. H.; Tan, Y. H.; Mubarak, N. M.; Kansedo, J.; Khalid, M.; Walvekar, R.; Abdullah, E. C.; J. Ind. Eng. Chem. 2020, 81, 41.

176. Sani, Y. M.; Daud, W. M. A. W.; Aziz, A. R. A.; Appl. Catal., A 2014, 470, 140.

177. Sharma, S.; Saxena, V.; Baranwal, A.; Chandra, P.; Pandey, L. M.; Mater. Sci. Energy Technol. 2018, 1, 11. 
178. de Lima, A. L.; Ronconi, C. M.; Mota, C. J. A.; Catal. Sci. Technol. 2016, 6, 2877.

179. Du, L.; Li, Z.; Ding, S.; Chen, C.; Qu, S.; Yi, W.; Lu, J.; Ding, J.; Fuel 2019, 258, 116122.

180. Roschat, W.; Phewphong, S.; Thangthong, A.; Moonsin, P.; Yoosuk, B.; Kaewpuang, T.; Promarak, V.; Energy Convers. Manage. 2018, 165, 1.

181. Lee, A. F.; Bennett, J. A.; Manayil, J. C.; Wilson, K.; Chem. Soc. Rev. 2014, 43, 7887.

182. Maleki, H.; Kazemeini, M.; Larimi, A. S.; Khorasheh, F.; J. Ind. Eng. Chem. 2017, 47, 399.

183. Silva, C. C. C. M.; Ribeiro, N. F. P.; Souza, M. M. V. M.; Aranda, D. A. G.; Fuel Process. Technol. 2010, 91, 205.

184. Dias, A. P. S.; Bernardo, J.; Felizardo, P.; Correia, M. J. N.; Energy 2012, 41, 344.

185. Corala, N.; Brasil, H.; Rodrigues, E.; da Costa, C. E. F.; Rumjanek, V.; Sustainable Chem. Pharm. 2019, 11, 49.

186. Navajas, A.; Campo, I.; Moral, A.; Echave, J.; Sanz, O.; Montes, M.; Odriozola, J. A.; Arzamendi, G.; Gandía, L. M.; Fuel 2018, $211,173$.

187. Nowicki, J.; Lach, J.; Organek, M.; Sabura, E.; Appl. Catal., A 2016, 524, 17.

188. de Lima, A. L.; Vieira, J. S. C.; Ronconi, C. M.; Mota, C. J. A.; Mol. Catal. 2018, 458, 240.

189. de Lima, A. L.; Mbengue, A.; San Gil, R. A. S.; Ronconi, C. M.; Mota, C. J. A.; Catal. Today 2014, 226, 210.

190. Sun, H.; Han, J.; Ding, Y.; Li, W.; Duan, J.; Chen, P.; Lou, H.; Zheng, X.; Appl. Catal., A 2010, 390, 26.

191. Filippousi, M.; Turner, S.; Katsikini, M.; Pinakidou, F.; Zamboulis, D.; Pavlidou, E.; van Tendeloo, G.; Microporous Mesoporous Mater. 2015, 210, 185.

192. Al-Ani, A.; Mordvinova, N. E.; Lebedev, O. I.; Khodakov, A. Y.; Zholobenko, V.; Energy Rep. 2019, 5, 357.

193. Baerlocher, C.; McCusker, L. B.; Olson, D. H.; Atlas of Zeolite Framework Types, $6^{\text {th }}$ ed.; Elsevier: Amsterdam, 2007.

194. Ramos, M. J.; Casas, A.; Rodríguez, L.; Romero, R.; Pérez, Á.; Appl. Catal., A 2008, 346, 79.

195. Ferrero, G. O.; Almeida, M. F.; Alvim-Ferraz, M. C. M.; Dias, J. M.; Fuel Process. Technol. 2014, 121, 114.

196. Maneerung, T.; Kawi, S.; Dai, Y.; Wang, C. H.; Energy Convers. Manage. 2016, 123, 487.

197. Teo, S. H.; Rashid, U.; Taufiq-Yap, Y. H.; Fuel 2014, 136, 244.

198. Mootabadi, H.; Salamatinia, B.; Bhatia, S.; Abdullah, A. Z.; Fuel 2010, 89, 1818.

199. Roschat, W.; Siritanon, T.; Yoosuk, B.; Promarak, V.; Energy Convers. Manage. 2016, 108, 459.

200. Calero, J.; Luna, D.; Sancho, E. D.; Luna, C.; Bautista, F. M.; Romero, A. A.; Posadillo, A.; Verdugo, C.; Fuel 2014, 122, 94.

201. Taufiq-Yap, Y. H.; Lee, H. V.; Yunus, R.; Juan, J. C.; Chem. Eng. J. 2011, 178, 342.

202. Teo, S. H.; Rashid, U.; Choong, S. Y. T.; Taufiq-Yap, Y. H.;
Energy Convers. Manage. 2017, 141, 20.

203. Lee, H. V.; Taufiq-Yap, Y. H.; Hussein, M. Z.; Yunus, R.; Energy 2013, 49, 12 .

204. Su, J.; Li, Y.; Wang, H.; Yan, X.; Pan, D.; Fan, B.; Li, R.; Chem. Phys. Lett. 2016, 663, 61.

205. Taufiq-Yap, Y. H.; Teo, S. H.; Rashid, U.; Islam, A.; Hussien, M. Z.; Lee, K. T.; Energy Convers. Manage. 2014, 88, 290.

206. Fan, M.; Liu, Y.; Zhang, P.; Jiang, P.; Fuel Process. Technol. 2016, 149, 163.

207. Xie, W.; Zhao, L.; Energy Convers. Manage. 2013, 76, 55.

208. Wen, Z.; Yu, X.; Tu, S. T.; Yan, J.; Dahlquist, E.; Bioresour. Technol. 2010, 101, 9570.

209. Mahesh, S. E.; Ramanathan, A.; Begum, K. M. M. S.; Narayanan, A.; Energy Convers. Manage. 2015, 91, 442.

210. Kaur, N.; Ali, A.; Fuel Process. Technol. 2014, 119, 173.

211. Wu, H.; Zhang, J.; Wei, Q.; Zheng, J.; Zhang, J.; Fuel Process. Technol., 2013, 109, 13.

212. Borges, L. D.; Moura, N. N.; Costa, A. A.; Braga, P. R. S.; Dias, J. A.; Dias, S. C. L.; de MacEdo, J. L.; Ghesti, G. F.; Appl. Catal., A 2013, 450, 114.

213. Noiroj, K.; Intarapong, P.; Luengnaruemitchai, A.; Jai-In, S.; Renewable Energy 2009, 34, 1145.

214. Kusuma, R. I.; Hadinoto, J. P.; Ayucitra, A.; Soetaredjo, F. E.; Ismadji, S.; Appl. Clay Sci. 2013, 74, 121.

215. Manadee, S.; Sophiphun, O.; Osakoo, N.; Supamathanon, N.; Kidkhunthod, P.; Chanlek, N.; Wittayakun, J.; Prayoonpokarach, S.; Fuel Process. Technol. 2017, 156, 62.

216. Saba, T.; Estephane, J.; El Khoury, B.; El Khoury, M.; Khazma, M.; El Zakhem, H.; Aouad, S.; Renewable Energy 2016, 90, 301.

217. Trakarnpruk, W.; Porntangjitlikit, S.; Renewable Energy 2008 , $33,1558$.

218. Santiago-Torres, N.; Romero-Ibarra, I. C.; Pfeiffer, H.; Fuel Process. Technol. 2014, 120, 34.

219. Xie, W.; Fan, M.; Bioresour. Technol. 2013, 139, 388.

220. Helwani, Z.; Aziz, N.; Bakar, M. Z. A.; Mukhtar, H.; Kim, J.; Othman, M. R.; Energy Convers. Manage. 2013, 73, 128.

221. Reyero, I.; Velasco, I.; Sanz, O.; Montes, M.; Arzamendi, G.; Gandía, L. M.; Catal. Today 2013, 216, 211.

222. Ma, Y.; Wang, Q.; Zheng, L.; Gao, Z.; Wang, Q.; Ma, Y.; Energy 2016, 107, 523.

223. Gomes, J. F. P.; Puna, J. F. B.; Gonçalves, L. M.; Bordado, J. C. M.; Energy 2011, 36, 6770.

224. Deng, X.; Fang, Z.; Liu, Y.; Yu, C. L.; Energy 2011, 36, 777.

225. Lu, Y.; Zhang, Z.; Xu, Y.; Liu, Q.; Qian, G.; Bioresour. Technol. 2015, 190, 438.

226. Salinas, D.; Araya, P.; Guerrero, S.; Appl. Catal., B 2012, 117 $118,260$.

227. Chen, G.; Shan, R.; Li, S.; Shi, J.; Fuel 2015, 153, 48.

228. Samart, C.; Chaiya, C.; Reubroycharoen, P.; Energy Convers. Manage. 2010, 51, 1428. 
229. Mahdavi, V.; Monajemi, A.; J. Taiwan Inst. Chem. Eng. 2014, 45, 2286.

230. Agarwal, M.; Chauhan, G.; Chaurasia, S. P.; Singh, K.; J. Taiwan Inst. Chem. Eng. 2012, 43, 89.

231. Chen, Y. H.; Huang, Y. H.; Lin, R. H.; Shang, N. C.; Chang, C. Y.; Chang, C. C.; Chiang, P. C.; Hu, C. Y.; J. Taiwan Inst. Chem. Eng. 2011, 42, 937.

232. Uprety, B. K.; Chaiwong, W.; Ewelike, C.; Rakshit, S. K.; Energy Convers. Manage. 2016, 115, 191.

233. Li, Y.; Qiu, F.; Yang, D.; Li, X.; Sun, P.; Biomass Bioenergy 2011, 35, 2787.

234. Kesić, Ž.; Lukić, I.; Zdujić, M.; Jovalekić, Č.; Veljković, V.; Skala, D.; Fuel Process. Technol. 2016, 143, 162.

235. Sandesh, S.; Kristachar, P. K. R.; Manjunathan, P.; Halgeri, A. B.; Shanbhag, G. V.; Appl. Catal., A 2016, 523, 1.

236. Kawashima, A.; Matsubara, K.; Honda, K.; Bioresour. Technol. 2008, 99, 3439 .

237. Zhang, P.; Han, Q.; Fan, M.; Jiang, P.; Appl. Surf. Sci. 2014, 317,1125

238. Xie, W.; Peng, H.; Chen, L.; Appl. Catal., A 2006, 300, 67.

239. Xie, W.; Yang, X.; Fan, M.; Renewable Energy 2015, 80, 230.

240. Balbino, J. M.; de Menezes, E. W.; Benvenutti, E. V.; Cataluña, R.; Ebeling, G.; Dupont, J.; Green Chem. 2011, 13, 3111.

241. Xie, W.; Fan, M.; Chem. Eng. J. 2014, 239, 60.

242. Meloni, D.; Monaci, R.; Zedde, Z.; Cutrufello, M. G.; Fiorilli, S.; Ferino, I.; Appl. Catal., B 2011, 102, 505.

243. Su, F.; Guo, Y.; Green Chem. 2014, 16, 2934.

244. Mardhiah, H. H.; Ong, H. C.; Masjuki, H. H.; Lim, S.; Lee, H. V.; Renewable Sustainable Energy Rev. 2017, 67, 1225.

245. Jiménez-Morales, I.; Santamaría-González, J.; Maireles-Torres, P.; Jiménez-López, A.; Appl. Catal., B 2011, 105, 199.

246. da Conceição, L. R. V.; Carneiro, L. M.; Giordani, D. S.; de Castro, H. F.; Renewable Energy 2017, 113, 119.

247. Kaur, M.; Malhotra, R.; Ali, A.; Renewable Energy 2018, 116, 109.

248. Zhang, P.; Wu, H.; Fana, M.; Sun, W.; Jiang, P.; Dong, Y.; Fuel 2019, 235, 426.

249. Chen, H.; Peng, B.; Wang, D.; Wang, J.; Front. Chem. Eng. China 2007, 1, 11.

250. Jitputti, J.; Kitiyanan, B.; Rangsunvigit, P.; Bunyakiat, K.; Attanatho, L.; Jenvanitpanjakul, P.; Chem. Eng. J. 2006, 116, 61.

251. Feng, Y.; Qiu, T.; Yang, J.; Li, L.; Wang, X.; Wang, H.; Chin. J. Chem. Eng. 2017, 25, 1222.

252. Shin, H. Y.; An, S. H.; Sheikh, R.; Park, Y. H.; Bae, S. Y.; Fuel 2012, 96, 572.

253. Babadi, F. E.; Hosseini, S.; Soltani, S. M.; Aroua, M. K.; Shamiri, A.; Samadi, M.; J. Am. Oil Chem. Soc. 2016, 93, 319.

254. Deshmane, C. A.; Wright, M. W.; Lachgar, A.; Rohlfing, M.; Liu, Z.; Le, J.; Hanson, B. E.; Bioresour. Technol. 2013, 147, 597.
255. Zhang, M.; Sun, A.; Meng, Y.; Wang, L.; Jiang, H.; Li, G.; Catal. Surv. Asia 2015, 19, 61.

256. Sandouqa, A.; Al-Hamamre, Z.; Asfar, J.; Renewable Energy 2019, 132, 667.

257. Jiménez-Morales, I.; Santamaría-González, J.; Maireles-Torres, P.; Jiménez-López, A.; Appl. Catal., B 2011, 103, 91.

258. Gardy, J.; Osatiashtiani, A.; Céspedes, O.; Hassanpour, A.; Lai, X.; Lee, A. F.; Wilson, K.; Rehan, M.; Appl. Catal., B 2018, 234, 268.

259. Peng, B. X.; Shu, Q.; Wang, J. F.; Wang, G. R.; Wang, D. Z.; Han, M. H.; Process Saf. Environ. Prot. 2008, 86, 441.

260. Lathiya, D. R.; Bhatt, D. V.; Maheria, K. C.; Bioresour. Technol. Rep. 2018, 2, 69.

261. Ding, H.; Ye, W.; Wang, Y.; Wang, X.; Li, L.; Liu, D.; Gui, J.; Song, C.; Ji, N.; Energy 2018, 144, 957.

262. Negm, N. A.; Sayed, G. H.; Yehia, F. Z.; Habib, O. I.; Mohamed, E. A.; J. Mol. Liq. 2017, 234, 157.

263. Nongbe, M. C.; Ekou, T.; Ekou, L.; Yao, K. B.; le Grognec, E.; Felpin, F. X.; Renewable Energy 2017, 106, 135.

264. Thushari, I.; Babel, S.; Bioresour. Technol. 2018, 248, 199.

265. Zhang, D.; Zhang, X.; Li, Y.; Wang, S.; Wang, X.; Jiang, Z.; Mater. Sci. Eng., C 2018, 92, 922.

266. Endut, A.; Abdullah, S. H. Y. S.; Hanapi, N. H. M.; Hamid, S. H. A.; Lananan, F.; Kamarudin, M. K. A.; Umar, R.; Juahir, H.; Khatoon, H.; Int. Biodeterior. Biodegrad. 2017, 124, 250.

267. Ma, Y.; Wang, Q.; Sun, X.; Wu, C.; Gao, Z.; Renewable Energy 2017, 107, 522.

268. Bala, D. D.; Misra, M.; Chidambaram, D.; J. Cleaner Prod. 2017, 142, 4169 .

269. Kimtun, P.; Choonut, O.; Yunu, T.; Paichid, N.; Klomkloa, S.; Sangkharak, K.; Energy Procedia 2015, 79, 822.

270. Soler, L.; Illanes, A.; Wilson, L.; Catal. Today 2016, 259, 177.

271. Pollardo, A. A.; Lee, H. S.; Lee, D.; Kim, S.; Kim, J.; J. Cleaner Prod. 2018, 185, 382.

272. Aarthy, M.; Saravanan, P.; Gowthaman, M. K.; Rose, C.; Kamini, N. R.; Chem. Eng. Res. Des. 2014, 92, 1591.

273. Budžaki, S.; Miljić, G.; Tišma, M.; Sundaram, S.; Hessel, V.; Appl. Energy 2017, 201, 124.

274. Moazeni, F.; Chen, Y.-C.; Zhang, G.; J. Cleaner Prod. 2019 , $216,117$.

275. Ognjanovic, N.; Bezbradica, D.; Knezevic-Jugovic, Z.; Bioresour. Technol. 2009, 100, 5146.

276. Köse, Ö.; Tüter, M.; Aksoy, H. A.; Bioresour. Technol. 2002, $83,125$.

277. Oliveira, D.; Oliveira, J. V.; J. Supercrit. Fluids 2001, 19, 141.

278. Royon, D.; Daz, M.; Ellenrieder, G.; Locatelli, S.; Bioresour. Technol. 2007, 98, 648.

279. Li, L.; Du, W.; Liu, D.; Wang, L.; Li, Z.; J. Mol. Catal. B: Enzym. 2006, 43, 58.

280. Gao, Y.; Tan, T. W.; Nie, K. L.; Wang, F.; Chin. J. Biotechnol. 2006, 22, 114. 
281. Soumanou, M. M.; Bornscheuer, U. T.; Enzyme Microb. Technol. 2003, 33, 97.

282. Bélafi-Bakó, K.; Kovács, F.; Gubicza, L.; Hancsók, J.; Biocatal. Biotransform. 2002, 20, 437.

283. Shieh, C. J.; Liao, H. F.; Lee, C. C.; Bioresour. Technol. 2003, $88,103$.

284. Abigor, R. D.; Uadia, P. O.; Foglia, T. A.; Haas, M. J.; Jones, K. C.; Okpefa, E.; Obibuzor, J. U.; Bafor, M. E.; Biochem. Soc. Trans. 2000, 28, 979.

285. Kumari, A.; Mahapatra, P.; Garlapati, V. K.; Banerjee, R.; Biotechnol. Biofuels 2009, 2, 1.

286. Kaieda, M.; Samukawa, T.; Kondo, A.; Fukuda, H.; J. Biosci. Bioeng. 2001, 91, 12.

287. de Oliveira, D.; do Nascimento Filho, I.; di Luccio, M.; Faccio, C.; Dalla Rosa, C.; Bender, J. P.; Lipke, N.; Amroginski, C.; Dariva, C.; de Oliveira, J. V.; Appl. Biochem. Biotechnol. 2005, 121-124, 231.

288. Jegannathan, K. R.; Jun-Yee, L.; Chan, E. S.; Ravindra, P.; Fuel 2010, 89, 2272.

289. Xie, W.; Wang, J.; Biomass Bioenergy 2012, 36, 373.

290. Tamalampudi, S.; Talukder, M. R.; Hama, S.; Numata, T.; Kondo, A.; Fukuda, H.; Biochem. Eng. J. 2008, 39, 185.

291. Zhang, K. P.; Lai, J. Q.; Huang, Z. L.; Yang, Z.; Bioresour. Technol. 2011, 102, 2767.

292. Yan, J.; Yan, Y.; Liu, S.; Hu, J.; Wang, G.; Bioresour. Technol. 2011, 102, 4755.

293. Sim, J. H.; Kamaruddin, A. H.; Bhatia, S.; J. Am. Oil Chem. Soc. 2010, 87, 1027.

294. Oliveira, A. C.; Rosa, M. F.; J. Am. Oil Chem. Soc. 2006, 83, 21.

295. https://www2.camara.leg.br/a-camara/estruturaadm/ altosestudos/pdf/biodiesel-e-inclusao-social/biodiesel-einclusao-social, accessed in February 2021.

296. Wright, H. J.; Segur, J. B.; Clark, H. V.; Coburn, S. K.; Langdon, E. E.; Dupuis, E. N.; Oil Soap 1944, 21, 145.

297. Fredman, B.; Butterfield, R. O.; Pryde, E. H.; J. Am. Oil Chem. Soc. 1986, 63, 1375.

298. Agência Nacional do Petróleo, Gás Natural e Biocombustíveis; Resolução ANP No. 45, de 25 de agosto de 2014, available at https://atosoficiais.com.br/anp/resolucao-n-45-2014?origin=instituicao, accessed in March 2021.

299. Alves, C. T.: Transesterificação de Óleos e Gorduras Residuais Via Rotas Metílica e Etílica Utilizando o Catalisador Aluminato de Zinco em Presença ou não de $\mathrm{CO}_{2}$ Supercrítico; $\mathrm{PhD}$ thesis, Universidade Federal da Bahia, Bahia, Brazil, 2012, available at http://repositorio.ufba.br/ri/handle/ri/23902, accessed in February 2021.

300. Ramos, L. P.; Silva, F. R.; Mangrich, A. S.; Cordeiro, C. S.; Rev. Virtual Quim. 2011, 3, 385.

301. Malek, M. N. F. A.; Hussin, N. M.; Embong, N. H.; Bhuyar, P.; Rahim, M. H. A.; Govindan, N.; Maniam, G. P.; Biomass Convers. Biorefin. 2020, DOI: 10.1007/s13399-020-01100-6.
302. Khedri, B.; Mostafaei, M.; Ardebili, S. M. S.; Energy Sources, Part A 2019, 41, 2377; Nayak, S. N.; Bhasin, C. P.; Nayak, M. G.; Renewable Energy 2019, 143, 1366.

303. Chuah, L. F.; Klemeš, J. J.; Yusup, S.; Bokhari, A.; Akbar, M. M.; J. Cleaner Prod. 2017, 146, 181; Gude, V. G.; Martinez-Guerra, E.; Environ. Chem. Lett. 2018, 16, 327; Günaya, M. E.; Türkerb, L.; Tapan, N. A.; Fuel 2019, 250, 27; Athar, M.; Zaidi, S.; J. Environ. Chem. Eng. 2020, 8, 104523; Bucciol, F.; Colia, M.; Gaudino, E. C.; Cravotto, G.; Catalysts 2020, 10, 988.

304. Tabatabaei, M.; Aghbashlo, M.; Dehhaghi, M.; Panahi, H. K. S.; Mollahosseini, A.; Hosseini, M.; Soufiyan, M. M.; Prog. Energy Combust. Sci. 2019, 74, 239.

305. Carrilho, E.; Tavares, M. C. H.; Lanças, F. M.; Quim Nova 2001, 24, 509 .

306. Toralles, L. P.: Hidrólise de Óleos e Gorduras Residuais em Água Subcrítica para Produção de Biodiesel; MSc dissertation, Universidade Federal da Bahia, Bahia, Brazil, 2016, available at http://docplayer.com.br/47467716-Hidrolise-de-oleos-egorduras-residuais-em-agua-subcritica-para-producao-debiodiesel.html, accessed in February 2021.

307. Chen, C.-H.; Chen, W.-H.; Chang, C.-M. J.; Lai, S. M.; Tu, C.-H.; J. Supercrit. Fluids 2010, 52, 228.

308. Savage, P. E.; Gopalan, S.; Mizan, T. I.; Martino, C. J.; Brock, E. E.; Chem. Eng. J. 1995, 41, 1723.

309. Jafari, A.; Esmaeilzadeh, F.; Mowla, D.; Sadatshojaei, E.; Heidari, S.; Wood, D. A.; Fuel 2021, 285, 119199.

310. Dermibas, A.; Energy Convers. Manage. 2002, 43, 2349.

311. Saka, S.; Kusdiana, D.; Fuel 2001, 80, 225.

312. Dermibas, A.; Energy Convers. Manage. 2007, 48, 937.

313. Cao, W.; Han, H.; Zhang, J.; Fuel 2005, 84, 347; Imahara, H.; Xin, J.; Saka, S.; Fuel 2009, 88, 1329.

314. Maçaira, J.; Santana, A.; Recasens, F.; Larrayoz, M. A.; Fuel 2011, 90, 2280.

315. Alenezi, R.; Leeke, G. A.; Winterbotton, J. M.; Santos, R. C. D.; Khan, A. R.; Energy Convers. Manage. 2010, 51, 1055.

316. Koh, A. D.: Two-Step Biodiesel Production Using Supercritical Methanol and Ethanol; $\mathrm{PhD}$ thesis, University of Iowa, Iowa, USA, 2011, available at https://ir.uiowa.edu/cgi/viewcontent. cgi? article $=2623 \&$ context=etd, accessed in February 2021.

317. Tsai, Y.; Lin, H.; Lee, M.; Bioresour. Technol. 2013, 145, 362.

318. Vieville, C.; Moulooungui, Z.; Gaset, A.; Ind. Eng. Chem. Res. 1993, 32, 2065.

319. Passman, F. J.; Int. Biodeterior. Biodegrad. 2013, 81, 88.

320. Varatharajan, K.; Pushparani, D. S.; Renewable Sustainable Energy Rev. 2018, 82, 2017.

321. Dunn, R. O.; Biofuels, Bioprod. Biorefin. 2008, 2, 304.

322. Knothe, G.; Fuel Process. Technol. 2007, 88, 669.

323. Bannister, C. D.; Chuck, C. J.; Bounds, M.; Hawley, J. G.; Proc. Inst. Mech. Eng., Part D 2011, 225, 99.

324. Fattah, I. M. R.; Masjuki, H. H.; Kalam, M. A.; Hazrat, M. 
A.; Masum, B. M.; Imtenan, S.; Ashraful, A. M.; Renewable Sustainable Energy Rev. 2014, 30, 356.

325. Yaakob, Z.; Narayanan, B. N.; Padikkaparambil, S.; Unni, K. S.; Akbar, P. M.; Renewable Sustainable Energy Rev. 2014, 35, 136.

326. Angelovič, M.; Jablonickỳ, J.; Tkáč, Z.; Angelovič, M.; Potravinarstvo 2015, 9, 417.

327. Kumar, N.; Fuel 2017, 190, 328.

328. Agarwal, S.; Singhal, S.; Singh, M.; Arora, S.; Tanwer, M.; ACS Sustainable Chem. Eng. 2018, 6, 11036.

329. Madiwale, S.; Karthikeyan, A.; Bhojwani, V.; IOP Conf. Ser.: Mater. Sci. Eng. 2017, 197, 012015; Kumar, M. V.; Babu, A. V.; Kumar, P. R.; Alexandria Eng. J. 2018, 57, 121; Ramalingam, S.; Rajendran, S.; Ganesan, P.; Govindasamy, M.; Renewable Sustainable Energy Rev. 2018, 81, 775.

330. Ramalho, V. C.; Jorge, N.; Quim. Nova 2006, 29, 755.

331. Dunn, R. O.; J. Am. Oil Chem. Soc. 2005, 82, 381; Dunn, R. O.; Fuel Process. Technol. 2005, 86, 1071; Valle, M. L. M.; Leonardo, R. S.; Dweck, J.; J. Therm. Anal. Calorim. 2014, 116, 113; Domingos, A. K.; Saad, E. B.; Vechiatto, W. W. D.; Wilhelm, H. M.; Ramos, L. P.; J. Braz. Chem. Soc. 2007, 18, 416; Ryu, K.; J. Mech. Sci. Technol. 2010, 23, 3105; Borsato, D.; Dall'Antonia, L. H.; Guedes, C. L. B.; Maia, E. C. R.; Freitas, H. R.; Moreira, I.; Spacino, K. R.; Quim. Nova 2010, 33, 1726; Tang, H.; Guzman, R. C. D.; Ng, K. Y. S.; Salley, S. O.; Energy Fuels 2010, 24, 2028; Tavares, M. L. A.; Queiroz, N.; Santos, I. M. G.; Souza, A. L.; Cavalcanti, E. H. S.; Barros, A. K. D.; Rosenhaim, R.; Soledade, L. E. B.; Souza, A. G.; J. Therm. Anal. Calorim. 2011, 106, 575; Maia, E. C. R.; Borsato, D.; Moreira, I.; Spacino, K. R.; Rodrigues, P. R. P.; Gallina, A. L.; Fuel Process. Technol. 2011, 92, 1750; Souza, F. H. N.; Maia, F. J. N.; Mazzetto, S. E.; Nascimento, T. L.; de Andrade, N.; Chem. Biochem. Eng. Q. 2013, 27, 327.

332. Focke, W. W.; van der Westhuizen, I.; Grobler, A. B. L.; Nshoane, K. T.; Reddy, J. K.; Luyt, A. S.; Fuel 2012, 94, 227.

333. Serrano, M.; Bouaid, A.; Martínez, M.; Aracil, J.; Fuel 2013, 113,50 .

334. Deligiannis, A.; Anastasakos, A.; Anastopoulos, G.; Dodos, G. S.; Zannikos, F.; SAE Tech. Pap. 2013, 1, 1128.

335. Serqueira, D. S.; Fernandes, D. M.; Cunha, R. R.; Squissato, A. L.; Santos, D. Q.; Richter, E. M.; Munoz, R. A. A.; Fuel 2014, $118,16$.

336. Ferrari, R. A.; de Souza, W. L.; Quim. Nova 2009, 32, 106; Karavalakis, G.; Hilari, D.; Givalou, L.; Karonis, D.; Stournas, S.; Energy 2011, 36, 369; Cursaru, D.; Neagu, M.; Bogatu, L.; Rev. Chim. 2013, 64, 438; van der Westhuizen, I.; Focke, W. W.; Fuel 2018, 219, 126.

337. Loh, S. K.; Chew, S. M.; Choo, Y. M.; J. Am. Oil Chem. Soc. 2006, 83, 947; Liang, Y. C.; May, C. Y.; Foon, C. S.; Ngan, M. A.; Hock, C. C.; Basiron, Y.; Fuel 2006, 85, 867; Lin, C. Y.; Chiu, C. C.; Energy Fuels 2009, 23, 3285; Lin, C. Y.; Chiu,
C. C.; Energy Convers. Manage. 2010, 51, 1464; Pullen, J.; Saeed, K.; Fuel Process. Technol. 2014, 125, 223; Susanto, B. H.; Lukman; Sutanto, H.; Nasikin, M.; IOP Conf. Ser.: Earth Environ. Sci. 2018, 105, 2.

338. Gan, S.; Ng, H. K.; Energy Convers. Manage. 2010, 51, 1536; Ryu, K.; Bioresour. Technol. 2010, 101, S78; Fattah, I. M. R.; Masjuki, H. H.; Kalam, M. A.; Wakil, M. A.; Ashraful, A. M.; Shahir, S. A.; Energy Convers. Manage. 2014, 83, 232.

339. Rashedul, H. K.; Masjuki, H. H.; Kalam, M. A.; Teoh, Y. H.; How, H. G.; Rizwanul Fattah, I. M.; Energy Convers. Manage. 2015, 106, 849.

340. Ramalingam, S.; Govindasamy, M.; Rajendran, S.; Therm. Sci. 2016, 20, S991; Velmurugan, K.; Sathiyagnanam, A. P.; Alexandria Eng. J. 2016, 55, 715; Ashok, B.; Nanthagopal, K.; Jeevanantham, A. K.; Bhowmick, P.; Malhotra, D.; Agarwal, P.; Energy Convers. Manage. 2017, 148, 935.

341. Adam, I. K.; Aziz, A. R. A.; Heikal, M. R.; Yusup, S.; Energy Fuels 2017, 31, 4424.

342. Rashedul, H. K.; Kalam, M. A.; Masjuki, H. H.; Teoh, Y. H.; How, H. G.; Monirul, I. M.; Imdadul, H. K.; Environ. Sci. Pollut. Res. 2017, 24, 9305.

343. Sharma, A.; Murugan, S.; Appl. Therm. Eng. 2017, 118, 365; Prabu, S. S.; Asokan, M. A.; Roy, R.; Francis, S.; Sreelekh, M. K.; Energy 2017, 122, 638.

344. Alagu, K.; Nagappan, B.; Jayaraman, J.; Arul Gnana Dhas, A.; Environ. Sci. Pollut. Res. 2018, 25, 17634.

345. Kivevele, T. T.; Kristóf, L.; Bereczky, Á.; Mbarawa, M. M.; Fuel 2011, 90, 2782.

346. Prabu, A.; Premkumar, I. J. I.; Pradeep, A.; Int. J. Ambient Energy 2020, 41, 121.

347. Reddy, V. P. K.; Kumar, D. S.; Thirumalini, S.; IOP Conf. Ser.: Mater. Sci. Eng. 2018, 310, 12116.

348. Sachuthananthan, B.; Balaji, G.; Krupakaran, R. L.; Int. J. Ambient Energy 2020, 41, 889.

349. Afzal, S.; Mumtaz, M. W.; Rashid, U.; Danish, M.; Raza, M. A.; Raza, A.; Mukhtar, H.; Al-Resayes, S. I.; Clean Technol. Environ. Policy 2018, 20, 589.

350. Halek, F.; Kavousi-Rahim, A.; Energy Environ. 2018, $29,732$.

351. Yamane, K.; Komiya, K.; Kondo, C.; Kawasaki, K.; SAE Int. J. Fuels Lubr. 2013, 6, 2013.

352. Ileri, E.; Koçar, G.; Energy Convers. Manage. 2013, 76, 145.

353. Jain, S.; Sharma, M. P.; Fuel 2013, 106, 152.

354. Balaji, G.; Cheralathan, M.; J. Energy Inst. 2014, 87, 188.

355. Fattah, I. M. R.; Hassan, M. H.; Kalam, M. A.; Atabani, A. E.; Abedin, M. J.; J. Cleaner Prod. 2014, 79, 82.

356. Fattah, I. M. R.; Masjuki, H. H.; Kalam, M. A.; Mofijur, M.; Abedin, M. J.; Energy Convers. Manage. 2014, 79, 265.

357. Fattah, I. M. R.; Masjuki, H. H.; Kalam, M. A.; Wakil, M. A.; Rashedul, H. K.; Abedin, M. J.; Ind. Crops Prod. 2014, 57, 132.

358. Beker, S. A.; da Silva, Y. P.; Bücker, F.; Cazarolli, J. C.; de 
Quadros, P. D.; Peralba, M. C. R.; Piatnicki, C. M. S.; Bento, F. M.; Fuel 2016, 184, 701.

359. Dodos, G. S.; Tsesmeli, C. E.; Zannikos, F.; Fuel 2017, 209, 150.

360. Tang, H.; Wang, A.; Salley, S. O.; Ng, K. Y. S.; J. Am. Oil Chem. Soc. 2008, 85, 373.

361. Zaleckas, E.; Makarevičienè, V.; Sendžikienè, E.; Transport 2012, 27, 60 .

362. Machado, Y. L.; Teles, U. M.; Dantas Neto, A. A.; Dantas, T. N. C.; Fonseca, J. L. C.; Fuel 2013, 112, 172.

363. Karčauskiene, D.; Sendžikiene, E.; Makarevičiene, V.; Zaleckas, E.; Repšiene, R.; Ambrazaitiene, D.; Zemdirbyste 2014, 101, 161.

364. Sirviö, K.; Niemi, S.; Vauhkonen, V.; Hiltunen, E.; Agron. Res. 2014, 12, 407.

365. Leonardo, R. S.; Valle, M. L. M.; Dweck, J.; J. Therm. Anal. Calorim. 2018, 131, 343

366. Dweck, J.; Leonardo, R. S.; Valle, M. L. M.; J. Therm. Anal. Calorim. 2013, 113, 1317.

367. Li, F.; Li, M.; Bao, G.; Wang, H.; Li, Y.; Du, W.; Li, X.; Asian J. Chem. 2014, 26, S217.

368. Singh, R. K.; Kukrety, A.; Sharma, O. P.; Baranwal, S.; Atray, N.; Ray, S. S.; J. Ind. Eng. Chem. 2016, 37, 27.

369. Singh, R. K.; Kukrety, A.; Sharma, O. P.; Poddar, M. K.; Atray, N.; Thakre, G. D.; Ray, S. S.; Waste Biomass Valorization 2016, 7, 1437.

370. Singh, R. K.; Kukrety, A.; Sharma, O. P.; Poddar, M. K.; Atray, N.; Ray, S. S.; Pet. Chem. 2017, 57, 100.

371. Muniz-Wypych, A. S.; da Costa, M. M.; Oliveira, A. R. S.; Neu, P. M.; Schober, S.; Mittelbach, M.; Ramos, L. P.; César-Oliveira, M. A. F.; Eur. J. Lipid Sci. Technol. 2017, 119, 1700179.

372. Rashed, M. M.; Masjuki, H. H.; Kalam, M. A.; Alabdulkarem, A.; Rahman, M. M.; Imdadul, H. K.; Rashedul, H. K.; Renewable Energy 2016, 94, 294.

373. Prabu, A.; Environ. Prog. Sustainable Energy 2017, 36, 565.

374. Kolanjiappan, V.; Rev. Fac. Ing., Univ. Antioquia 2017, 2017, 46.

375. Ramalingam, S.; Rajendran, S.; SAE Int. J. Fuels Lubr. 2017, 10, 2017.

376. Ashok, B.; Nanthagopal, K.; Subbarao, R.; Johny, A.; Mohan, A.; Tamilarasu, A.; J. Cleaner Prod. 2017, 166, 474.

377. Palash, S. M.; Kalam, M. A.; Masjuki, H. H.; Masum, B. M.; Adv. Mater. Res. 2013, 774-776, 784.

378. Varatharajan, K.; Cheralathan, M.; Fuel Process. Technol. 2013, 106, 526.

379. Palash, S. M.; Kalam, M.A.; Masjuki, H. H.; Arbab, M. I.; Masum, B. M.; Sanjid, A.; Energy Convers. Manage. 2014, 77, 577.

380. Prabu, A.; Anand, R. B.; Front. Energy 2015, 9, 238.

381. Rashed, M. M.; Kalam, M. A.; Masjuki, H. H.; Habibullah, M.; Imdadul, H. K.; Shahin, M. M.; Rahman, M. M.; Ind. Crops Prod. 2016, 89, 273.
382. Rashed, M. M.; Masjuki, H. H.; Kalam, M. A.; Alabdulkarem, A.; Imdadul, H. K.; Rashedul, H. K.; Shahin, M. M.; Habibullah, M.; RSC Adv. 2016, 6, 22436.

383. Alberici, R. M.; Simas, R. C.; Abdelnur, P. V.; Eberlin, M. N.; de Souza, V.; de Sá, G. F.; Daroda, R. J.; Energy Fuels 2010, 24, 6522 .

384. Chen, Y. H.; Luo, Y. M.; Fuel Process. Technol. 2011, 92, 1387.

385. Alberici, R. M.; de Souza, V.; de Sá, G. F.; Morelli, S. R.; Eberlin, M. N.; Daroda, R. J.; Bioenergy Res. 2012, 5, 1002.

386. Chen, Y. H.; Tang, T. C.; Chiang, T. H.; Huang, B. Y.; Chang, C. Y.; Chiang, P. C.; Shie, J. L.; Franzreb, M.; Chen, L. Y.; Energies 2012, 5, 3137.

387. Subroto, E.; Manurung, R.; Heeres, H. J.; Broekhuis, A. A.; Eur. J. Lipid Sci. Technol. 2013, 115, 909.

388. Bär, F.; Hopf, H.; Knorr, M.; Krahl, J.; Fuel 2018, 215, 249.

389. Bär, F.; Hopf, H.; Knorr, M.; Krahl, J.; Fuel 2018, 232, 108.

390. Dodson, J. R.; Avellar, T.; Athayde, J.; Mota, C. J. A.; Pure Appl. Chem. 2014, 86, 905.

391. El-Boulifi, N.; Ashari, S. E.; Serrano, M.; Aracil, J.; Martínez, M.; Enzyme Microb. Technol. 2014, 55, 128.

392. Schirmann, J. G.; Dekker, R. F. H.; Borsato, D.; BarbosaDekker, A. M.; Appl. Catal., A 2018, 555, 88.

393. Schirmann, J. G.; Angilelli, K. G.; Dekker, R. F. H.; Borsato, D.; Barbosa-Dekker, A. M.; Fuel 2019, 237, 593.

394. Sui, M.; Li, F.; Renewable Energy 2019, 143, 352.

395. Figueredo, I. D. M.; Rios, M. A. D. S.; Cavalcante, C. L.; Luna, F. M. T.; Ind. Eng. Chem. Res. 2020, 59, 18.

396. Varatharajan, K.; Cheralathan, M.; Velraj, R.; Fuel 2011, 90, 2721.

397. Usta, N.; Aydoğan, B.; On, A. H.; Uğuzdǒan, E.; Özkal, S. G.; Energy Convers. Manage. 2011, 52, 2031.

398. Santos, N. A.; Cordeiro, A. M. T. M.; Damasceno, S. S.; Aguiar, R. T.; Rosenhaim, R.; Carvalho Filho, J. R.; Santos, I. M. G.; Maia, A. S.; Souza, A. G.; Fuel 2012, 97, 638.

399. Moser, B. R.; Renewable Energy 2012, 40, 65.

400. Luo, M.; Zhang, R. Y.; Zheng, Z.; Wang, J. L.; Ji, J. B.; J. Braz. Chem. Soc. 2012, 23, 241.

401. Pinto, L. M.; de Souza, A. L.; Souza, A. G.; Santos, I. M. G.; Queiroz, N.; J. Therm. Anal. Calorim. 2015, 120, 277.

402. Balaji, G.; Cheralathan, M.; Energy Sources, Part A 2016, 38, 2454.

403. Ramalingam, S.; Ganesan, P.; Rajendran, S.; Therm. Sci. 2016, 20, S967.

404. Tahmasebi, S. E.; Rabiei, Z.; Vannozzi, G. P.; Helia 2006, 29 , 25.

405. Moser, B. R.; Eur. J. Lipid Sci. Technol. 2008, 110, 1167.

406. El Diwani, G.; El Rafie, S.; Hawash, S.; Int. J. Environ. Sci. Technol. 2009, 6, 369.

407. Sarin, A.; Singh, N. P.; Sarin, R.; Malhotra, R. K.; Energy 2010 , 35,4645 .

408. Joshi, H.; Moser, B. R.; Shah, S. N.; Mandalika, A.; Walker, T.; Eur. J. Lipid Sci. Technol. 2010, 112, 802. 
409. Balaji, G.; Cheralathan, M.; Int. J. Ambient Energy 2014, 35, 13.

410. Takase, M.; Chen, Y.; Liu, H.; Zhao, T.; Yang, L.; Wu, X.; Ultrason. Sonochem. 2014, 21, 1752.

411. Ramalingam, S.; Kaliyaperumal, A.; Govindasamy, M.; Ezhumalai, M.; Kumar, C.; Therm. Sci. 2016, 20, S999.

412. Santos, N. A.; Damasceno, S. S.; de Araújo, P. H. M.; Marques, V. C.; Rosenhaim, R.; Fernandes, V. J.; Queiroz, N.; Santos, I. M. G.; Maia, A. S.; Souza, A. G.; Energy Fuels 2011, 25, 4190.

413. Damasceno, S. S.; Santos, N. A.; Santos, I. M. G.; Souza, A. L.; Souza, A. G.; Queiroz, N.; Fuel 2013, 107, 641.

414. Saifuddin, N.; Refal, H.; Res. J. Appl. Sci. Eng. Technol. 2014, 8,1149 .

415. Alexandrino, C. D.; Morais, S. M.; Oliveira, M. S. C.; Machado, L. K. A.; Martins, C. G.; Craveiro, A. A.; Rocha, N. C.; Valle, C. P.; Malveira, J. Q.; Jorge, F. A. S.; Eur. J. Lipid Sci. Technol. 2013, 115, 709.

416. Romagnoli, É. S.; Borsato, D.; Silva, L. R. C.; Tashima, D. L. M.; Canesin, E. A.; Biofuels 2020, 11, 839.

417. Nogueira, T. R.; Figueredo, I. M.; Luna, F. M. T.; Cavalcante, C. L.; dos Santos Jr., J. E. Á.; Lima, M. A. S.; da Silva, T. S. J.; Leal, L. K. A. M.; Nunes, F. M.; Rios, M. A. S.; Pimenta, A. T. Á.; Renewable Energy 2020, 159, 767.

418. Yatish, K.V.; Lalithamba, H. S.; Sakar, M.; Balakrishna, G. R.; Omkaresh, B. R.; Arun, S. B.; Int. J. Energy Res. 2020, 44, 11711.

419. Correia, I. A. S.; Borsato, D.; Savada, F. Y.; Pauli, E. D.; Mantovani, A. C. G.; Cremasco, H.; Chendynski, L. T.; Renewable Energy 2020, 160, 288.

420. Rial, R. C.; Merlo, T. C.; Santos, P. H. M.; Melo, L. F. D.; Barbosa, R. A.; de Freitas, O. N.; Nazário, C. E. D.; Viana, L. H.; Renewable Energy 2020, 152, 1079.

421. Medeiros, M. L.; Cordeiro, A. M. M. T.; Queiroz, N.; Soledade, L. E. B.; Souza, A. L.; Souza, A. G.; Energy Fuels 2014, 28, 1074.

422. Coppo, R. L.; Pereira, J. L.; Da, H. C. S.; Angilelli, K. G.; Rodrigues, P. R. P.; Galvan, D.; Borsato, D.; J. Biobased Mater. Bioenergy 2014, 8, 545.

423. Spacino, K. R.; Borsato, D.; Buosi, G. M.; Chendynski, L. T.; Fuel Process. Technol. 2015, 137, 366.

424. Buosi, G. M.; da Silva, E. T.; Spacino, K.; Silva, L. R. C.; Ferreira, B. A. D.; Borsato, D.; Fuel 2016, 181, 759.

425. Spacino, K. R.; Silva, E. T. da; Angilelli, K. G.; Moreira, I.; Galão, O. F.; Borsato, D.; Ind. Crops Prod. 2016, 80, 109.

426. Chendynski, L. T.; Signori Romagnoli, É.; da Silva, P. R. C.; Borsato, D.; Energy Fuels 2017, 31, 9613.

427. Narayanasamy, B.; Jeyakumar, N.; Manoharan, D. K.; Energy Sources, Part A 2018, 40, 680.

428. Nivetha, S.; Roy, D. V.; J. Energy Chem. 2013, 22, 935.

429. Kang, S.; Li, X.; Li, B.; Fan, J.; Chang, J.; Energy Fuels 2011 , $25,2746$.
430. Barsberg, S.; Thygesen, L. G.; Sanadi, A. R.; Energy Fuels 2014, 28, 4539.

431. Chandrasekaran, S. R.; Murali, D.; Marley, K. A.; Larson, R. A.; Doll, K. M.; Moser, B. R.; Scott, J.; Sharma, B. K.; ACS Sustainable Chem. Eng. 2016, 4, 1414.

432. Gil-Lalaguna, N.; Bautista, A.; Gonzalo, A.; Sánchez, J. L.; Arauzo, J.; Fuel Process. Technol. 2017, 166, 1.

433. Larson, R. A.; Sharma, B. K.; Marley, K. A.; Kunwar, B.; Murali, D.; Scott, J.; Ind. Crops Prod. 2017, 109, 476.

434. da Silva-Araújo, F. D.; de Moura, C. V. R.; Chaves, M. H.; Quim. Nova 2010, 33, 1671.

435. Sánchez, L.; Chávez, J.; Ríos, L. A.; Cardona, S. M.; Inf. Tecnol. 2015, 26, 19.

436. Kleinberg, M. N.; Rios, M. A. S.; Buarque, H. L. B.; Parente, M. M. V.; Cavalcante, C. L.; Luna, F. M. T.; Waste Biomass Valorization 2017, 10, 797.

437. Bastos, F. A.; Tubino, M.; J. Braz. Chem. Soc. 2017, $28,747$.

438. Rodrigues, F. M. G.; Souza, A. G.; Santos, I. M. G.; Bicudo, T. C.; Silva, M. C. D.; Sinfrônio, F. S. M.; Vasconselos, A. F. F.; J. Therm. Anal. Calorim. 2009, 97, 605.

439. Lomonaco, D.; Maia, F. J. N.; Clemente, C. S.; Mota, J. P. F.; Costa, A. E.; Mazzetto, S. E.; Fuel 2012, 97, 552.

440. Maia, F. J. N.; Ribeiro, F. W. P.; Rangel, J. H. G.; Lomonaco, D.; Luna, F. M. T.; de Lima-Neto, P.; Correia, A. N.; Mazzetto, S. E.; Ind. Crops Prod. 2015, 67, 281.

441. dos Santos, R. C.; Amorim, A. D. G. N.; Thomasi, S. S.; Figueiredo, F. C.; Carneiro, C. S.; da Silva, P. R. P.; de Vasconcelos Neto, W. R.; Ferreira, A. G.; dos Santos Jr., J. R.; Leite, J. R. D. S. D. A.; Fuel 2015, 144, 415.

442. Liu, Z.; Chen, J.; Knothe, G.; Nie, X.; Jiang, J.; ACS Sustainable Chem. Eng. 2016, 4, 901.

443. Costa, K. P.; de Viveiros, B. M.; Schmidt Jr., M. A. S.; Suarez, P. A. Z.; Rezende, M. J. C.; Fuel 2019, 235, 1010.

444. Bento, F. M.; Gaylarde, C. C.; Int. Biodeterior. Biodegrad. 2001, 47, 107.

445. Bücker, F.; Barbosa, C. S.; Quadros, P. D.; Bueno, M. K.; Fiori, P.; Huang, C.; Frazzon, A. P. G.; Ferrão, M. F.; Camargo, F. A. O.; Bento, F. M.; Int. Biodeterior. Biodegrad. 2014, 95, 346.

446. Gaylarde, C. C.; Bento, F. M.; Kelley, J.; Rev. Microbiol. 1999, 30,1 .

447. Bautista, L. F.; Vargas, C.; González, N.; Molina, M. C.; Simarro, R.; Salmerón, A.; Murillo, Y.; Fuel Process. Technol. 2016, $152,56$.

448. Meyer, D. D.; Beker, S. A.; Bücker, F.; Peralba, M. C. R.; Frazzon, A. P. G.; Osti, J. F.; Andreazza, R.; Camargo, F. A. O.; Bento, F. M.; Int. Biodeterior. Biodegrad. 2014, 95, 356.

449. Pasqualino, J. C.; Montané, D.; Salvadó, J.; Biomass Bioenergy 2006, $30,874$.

450. Jakeria, M. R.; Fazal, M. A.; Haseeb, A. S. M. A.; Renewable Sustainable Energy Rev. 2014, 30, 154.

451. Chao, Y.; Liu, N.; Zhang, T.; Chen, S.; Fuel 2010, 89, 3358. 
452. Cazarolli, J. C.; Boelter, G.; de Lima, A. M. D. L.; Hengles, T.; Correa, C.; Peralba, M. C. R.; Ferrão, M. F.; Cavalcanti, E. H. S.; Bisol, M. V.; Bezerra, K. S.; Antoniosi Filho, N. R.; Bento, F. M.; J. Braz. Chem. Soc. 2018, 29, 2034.

453. Schleicher, T.; Werkmeister, R.; Russ, W.; Meyer-Pittroff, R.; Bioresour. Technol. 2009, 100, 724.

454. Bücker, F.; Santestevan, N. A.; Roesch, L. F.; Jacques, R. J. S.; Peralba, M. C. R.; Camargo, F. A. O.; Bento, F. M.; Int. Biodeterior. Biodegrad. 2011, 65, 172.

455. Sørensen, G.; Pedersen, D. V.; Nørgaard, A. K.; Sørensen, K. B.; Nygaard, S. D.; Bioresour. Technol. 2011, 102, 5259.

456. Cazarolli, J. C.; Bücker, F.; Manique, M. C.; Krause, L. C.; Maciel, G. P. S.; Onorevoli, B.; Caramão, E. B.; Cavalcanti, E. H. S.; Samios, D.; Peralba, M. C. R.; Bento, F. M.; Rev. Bras. Bioci. 2012, 10, 251.

457. Cazarolli, J. C.; Guzatto, R.; Samios, D.; Peralba, M. C. R.; Cavalcanti, E. H. S.; Bento, F. M.; Int. Biodeterior. Biodegrad. 2014, 95, 364.

458. Soriano, A. U.; Martins, L. F.; Ventura, E. S. A.; Landa, F. H. T. G.; Valoni, E. A.; Faria, F. R. D.; Ferreira, R. F.; Faller, M. C. K.; Valério, R. R.; Leite, D. C. A.; Carmo, F. L.; Peixoto, R. S.; Int. Biodeterior. Biodegrad. 2015, 99, 102.

459. Cavalcanti, E. H. S.; Zimmer, A. R.; Bento, F. M.; Ferrão, M. F.; Fuel 2019, 236, 993.

460. Military Specification, Stabilizer Additive, Diesel Fuel, MIL-S53021A, 1988, available at http://everyspec.com/MIL-SPECS/ MIL-SPECS-MIL-S/MIL-S-53021A_8396/, accessed in March 2021.

461. Zimmer, A.; Cazarolli, J.; Teixeira, R. M.; Viscardi, S. L. C.; Cavalcanti, E. S. H.; Gerbase, A. E.; Ferrão, M. F.; Piatnicki, C. M. S.; Bento, F. M.; Fuel 2013, 112, 153.

462. Zimmer, A. R.; Oliboni, A.; Viscardi, S. L. C.; Teixeira, R. M.; Ferrão, M. F.; Bento, F. M.; Biofuel Res. J. 2017, 14, 627.

463. ASTM E1259-10: Standard Practice for Evaluation of Antimicrobials in Liquid Fuels Boiling Below $390{ }^{\circ} \mathrm{C}$, West Conshohocken, PA, 2010.

464. Santos, G. A.; Vila, M. M. D. C.; Chaud, M. V.; Silva, W. L.; Castro, A. G.; Oliveira Jr., J. M.; Tubino, M.; Balcão, V. M.; Biofuels 2016, 7, 581.

465. Ramalho, H. F.; Ferreira, K. M. C.; Machado, P. M. A.; Silva, T. B.; Rangel, E. T.; Prauchner, M. J.; Suarez, P. A. Z.; J. Braz. Chem. Soc. 2016, 27, 321.

466. Oliveira, R. S.; Machado, P. M. A.; Ramalho, H. F.; Rangel, E. T.; Suarez, P. A. Z.; Ind. Crops Prod. 2017, 104, 201.

467. Costa, K. P.; do Valle, S. F.; dos Santos, T. F. L.; Rangel, E. T.; Pinto, A. C.; Suarez, P. A. Z.; Rezende, M. J. C.; J. Braz. Chem. Soc. 2018, 29, 2605.

468. http://www.who.int/airpollution/en/, accessed in February 2021; https://www.who.int/data/gho/data/themes/topics/indicatorgroups/indicator-group-details/GHO/ambient-air-pollution, accessed in February 2021; https://www.euro.who.int/en/ health-topics/environment-and-health/urban-health/news/ news/2013/10/outdoor-air-pollution-a-leading-environmentalcause-of-cancer-deaths, accessed in February 2021.

469. https://www.iarc.who.int/wp-content/uploads/2018/07/ pr221_E.pdf, accessed in March 2021.

470. Mofijur, M.; Rasul, M. G.; Hyde, J.; Azad, A. K.; Mamat, R.; Bhuiya, M. M. K. Renewable Sustainable Energy Rev. 2016, $53,265$.

471. Shamuna, S.; Belgiornob, G.; Di Blasiob, G.; Beatriceb, C.; Tunéra, M.; Tuneståla, P.; Appl. Therm. Eng. 2018, 145, 444.

472. Zheng, Z.; Xia, M.; Liu, H.; Wang, X.; Yao, M.; Energy 2018 , $148,824$.

473. Wei, L; Cheung, C. S.; Ning, Z.; Energy 2018, 155, 957.

474. Bayındır, H.; Zerrakki, M.; Argunhan, Z.; Yücel, H. L.; Aydın, H.; Energy 2017, 123, 241.

475. Guarieiro, L. L. N.; Guerreiro, E. T. A.; Amparo, K. K. S.; Manera, V. B.; Regis, A. C. D.; Santos, A. G.; Ferreira, V. P.; Leão, D. J.; Torres, E. A.; de Andrade, J. B.; Microchem. J. 2014, 117, 94.

476. Melo, C. I. M.; Sousa, E. T.; da Rocha, G. O.; dos Anjos, J. P.; de Andrade, J. B.; Talanta 2020, 217, 121033.

477. de Jesus, R. M.; Mosca, A. C.; Guarieiro, A. L. N.; da Rocha, G. O.; de Andrade, J. B.; J. Braz. Chem. Soc. 2018, 29, 1268.

478. Santos, A. G.; Regis, A. C. D.; da Rocha, G. O.; Bezerra, M.; de Jesus, R. M.; de Andrade, J. B.; J. Chromatogr., A 2016, 1435, 6.

479. Sousa, E. T.; Cardoso, M. P.; Silva, L.A.; de Andrade, J. B.; Microchem. J. 2015, 118, 26.

480. Guarieiro, A. L. N.; Santos, J. V. S.; Fernandez, A. E.; Torres, E. A.; da Rocha, G. O.; de Andrade, J. B.; Fuel 2014, 116, 490.

481. Martins, L. D.; Júnior, C. R. S.; Solci, M. C.; Pinto, J. P.; Souza, D. Z.; Vasconcellos, P.; Guarieiro, A. L. N.; Guarieiro, L. L. N.; Sousa, E. T.; de Andrade, J. B.; Environ. Monit. Assess. 2012, 184, 2663.

482. da Rocha, G. O.; Lopes, W. A.; Pereira, P. A. P.; Vasconcellos, P. C.; Oliveira, F. S.; Carvalho, L. S.; Conceição, L. S.; de Andrade, J. B.; J. Braz. Chem. Soc. 2009, 20, 680.

483. Guarieiro, L. L. N.; de Souza, A. F.; Torres, E. A.; de Andrade, J. B.; Atmos. Environ. 2009, 43, 2754.

484. Rodrigues, M. C.; Guarieiro, L. L. N.; Cardoso, M. P.; Carvalho, L. S.; da Rocha, G. O.; de Andrade, J. B.; Fuel 2011, 92, 258.

485. Yilmaz, N.; Davis, S. M.; Fuel 2016, 181, 729.

486. Allen, A. G.; da Rocha, G. O.; Cardoso, A. A.; Paterlini, W. C.; Machado, C. M. D.; de Andrade, J. B.; Transp. Res. D 2008, 13,483 .

487. Machado, M. C. S.; Loyola, J.; Quiterio, S. L.; da Rocha, G. O.; de Andrade, J. B.; Arbilla, C.; J. Braz. Chem. Soc. 2009, 20,1565 .

488. Guarieiro, L. L. N.; Pereira, P. A P.; Torres, E. A.; da Rocha, G. O.; de Andrade, J. B.; Atmos. Environ. 2008, 42, 8211.

489. Corrêa, S. M.; Arbilla, G.; Atmos. Environ. 2008, 42, 769. 
490. He, C.; Ge, Y.; Tan, J.; You, K.; Han, X.; Wang, J.; You, Q.; Shah, A. N.; Atmos. Environ. 2009, 43, 3657.

491. Santos, A. G.; da Rocha, G. O.; de Andrade, J. B.; Sci. Rep. 2019, $9,1$.

492. Mkoma, S. L.; da Rocha, G. O.; Regis, A. C. D.; Domingos, J. S. S.; Santos, J. V. S.; de Andrade, S. J.; Carvalho, L. S.; de Andrade, J. B.; Fuel 2014, 115, 109.

493. Karavalakis, G.; Boutsika, V.; Stournas, S.; Bakeas, E.; Sci. Total Environ. 2011, 409, 738.

494. Tadano, Y.; Borillo, G.; Godoi, A.; Cichon, A.; Silva, T.; Valebona, F.; Errera, M.; Neto, R.; Rempel, D.; Martin, L.; Yamamoto, C.; Godoi R.; Sci. Total Environ. 2014, 500-501, 64.

495. Ballesteros, R.; Flores, J. G.; Martinez, J. D.; Chemosphere 2014, 96, 155.

496. Huang, L.; Bohac, S. V.; Chernyak, S. M.; Batterman, S. A.; Atmos. Environ. 2015, 102, 228.

497. Huber, C. S.; Vale, M. G. R.; Welz, B.; de Andrade, J. B.; Dessuy, M. B.; Spectrochim. Acta, Part B 2015, 108, 68.

498. Agarwal, A. K.; Shukla, P. C.; Patel, C.; Gupta, J. G.; Sharma, N.; Prasad, R. K.; Agarwal, R. A.; Renewable Energy 2016, 98 , 283.

499. Guarieiro, A. L. N.; Fernandez, A. E.; da Rocha, G. O.; de Andrade, J. B.; J. Braz. Chem. Soc. 2017, 28, 1351.
500. Tan, P.-Q.; Zhong, Y.-M.; Hu, Z.-Y.; Lou, D.-M.; Energy 2017, $141,898$.

501. Wei, L.; Cheung, C. S.; Ning, Z.; Energy 2017, 127, 175.

502. Borillo, G. C.; Tadano, Y. S.; Godoi, A. F. L.; Pauliquevis, T.; Sarmiento, H.; Rempel, D.; Yamamoto, C. I.; Marchi, M. R. R.; Vermaak, S. P.; Godoi, R. H. M.; Sci. Total Environ. 2018, 644,675

503. Ghadikolaei, M. A.; Wei, L.; Cheung, C. S.; Yung, K.-F.; Sci. Total Environ. 2019, 658, 1117.

504. Zhang, Y.; Lou, D.; Hu, Z.; Tan, P.; J. Cleaner Production 2019, 225,627

505. Placencia, F.; Fadic, X.; Yáñez, K.; Balic, F. C.; Sci. Total Environ. 2019, 651, 2597.

506. Cheruiyot, N. K.; Hou, W. C.; Wang, L. C.; Chen, C. Y.; Chemosphere 2019, 235, 726.

507. Ballesteros, R.; Ramos, A.; Sánchez-Valdepeñas, J.; J. Energy Inst. 2020, 93, 1970.

508. https://clarivate.com/derwent/solutions/derwent-innovation/, accessed in April 2021.

509. https://news.trust.org/item/20201118095737-8h1uh, accessed in February 2021

Submitted: November 30, 2020

Published online: April 8, 2021 